UNIVERSIDADE DE SÃO PAULO

INSTITUTO DE FÍSICA DE SÃO CARLOS

KARINA DE PAULA

Estudos estruturais de novos ligantes sintéticos do receptor PPARY

São Carlos 

KARINA DE PAULA

\section{Estudos estruturais de novos ligantes sintéticos do receptor PPARY}

Tese apresentada ao Programa de PósGraduação em Física do Instituto de Física de São Carlos da Universidade de São Paulo, para obtenção do título de Doutora em Ciências.

Área de concentração: Física Aplicada Opção: Física Biomolecular Orientador: Prof. Dr. Alessandro Silva Nascimento.

\section{Versão Corrigida}

(Versão original disponível na Unidade que aloja o Programa)

São Carlos 
AUTORIZO A REPRODUÇÃO E DIVULGAÇÃO TOTAL OU PARCIAL DESTE TRABALHO, POR QUALQÜER MEIO CONVENCIONAL OU ELETRÔNICO PARA FINS DE ESTUDO E PESQUISA, DESDE QUE CITADA A FONTE.

Ficha catalográfica revisada pelo Serviço de Biblioteca e Informação do IFSC, com os dados fornecidos pelo(a) autor(a)

Paula, Karina de

Estudos estruturais de novos ligantes sintéticos do receptor PPAR gama / Karina de Paula; orientador Alessandro Silva Nascimento - versão corrigida -São Carlos, 2017.

$104 \mathrm{p}$.

Tese (Doutorado - Programa de Pós-Graduação em Física Biomolecular) -- Instituto de Física de São Carlos, Universidade de São Paulo, 2017.

1. Receptores nucleares. 2. Receptor ativador da proliferação de peroxissomos. 3. Agonista parcial. I. Nascimento, Alessandro Silva, orient. II. Título. 
Dedico esta Tese aos meus pais Donizetti e Janete por todo apoio e amor incondicional, por toda dedicação e por me ajudar a nunca desistir. Ao meu marido Rodrigo e minha filha Lorena por sempre estarem ao meu lado. 



\section{AGRADECIMENTOS}

À Deus por sempre me dar força e coragem para continuar.

Ao Prof.. Dr. Alessandro Silva Nascimento, pela orientação, confiança para a realização do meu trabalho, pela compreensão, pelo apoio e suporte.

Ao Instituto de Física de São Carlos da Universidade de São Paulo pela oportunidade.

Ao Grupo de Biotecnologia Molecular principalmente o pessoal da sala 9: Érika, Heloísa, Mariana, Érick, João Vitor, Stheffany e Vitor pela ajuda nos trabalhos e por todo o apoio e amizade, também pelo nosso cafezinho e saidinhas.

Aos meus pais Donizetti e Jane por sempre me mostrarem o certo e me apoiando em todas as coisas, em todos os momentos.

A toda a minha família: tios, primos, vós e aos meus amigos que sempre me deram coragem também para chegar até aqui.

Ao Rodrigo Romano pelo seu companheirismo, paciência e amor e minha filha Lorena por ter sido mais um resultado no meio do meu doutorado que me fez conhecer o amor verdadeiro.

A minha amiga Ana Carolina Mafud por toda a ajuda e amizade mesmo longe, durante as madrugadas sempre me acalmando e me dando apoio e um empurrãozinho.

Aos técnicos do Grupo de Biotecnologia Molecular Lívia, Josimar, João Possato e Maria.

Aos funcionários do serviço de pós-graduação e as funcionárias do serviço de biblioteca do IFSC-USP pela prestatividade em todos os momentos.

À Coordenação de Aperfeiçoamento de Pessoal de Nível superior CAPES pela bolsa concedida. 

Agradeço todas as dificuldades que enfrentei; Se não fosse por elas, eu não teria saído do lugar.

As facilidades nos impedem de caminhar.

Mesmo as críticas nos auxiliam muito.

(Chico Xavier) 



\section{RESUMO}

PAULA, K. de. Estudos estruturais de novos ligantes sintéticos do receptor PPARy. 2017. 104 p. Tese (Doutorado em Ciências) - Instituto de Física de São Carlos, Universidade de São Paulo, São Carlos, 2017.

Os receptores nucleares compreendem uma superfamília de proteínas intracelulares reguladas relacionados estruturalmente, capazes de reconhecer sequências específicas de DNA e regulam a transcrição de genes alvos respondendo a sinais metabólicos, hormônios e outras moléculas regulatórias integrando muitas vias de sinalização. Os receptores ativadores da proliferação de peroxissomos (PPARs) são receptores nucleares que regem a transcrição de vários genes envolvidos principalmente no metabolismo de ácidos graxos e energia. A ativação do PPARY possui um amplo aspecto de funções biológicas, regulando o metabolismo, reduzindo a inflamação, influenciando o equilíbrio das células imunes, inibindo a apoptose e o estresse oxidativo e melhorando a função endotelial. Estes efeitos parecem ser benéficos não apenas em diabetes e aterosclerose, mas também em várias outras condições. Os agonistas do PPARY são utilizados como sensibilizadores de insulina para o tratamento da diabetes II, sendo um alvo molecular dos fármacos tiazolidinadionas. Diversos efeitos colaterais severos associados ao uso dos fármacos desta classe e à importância do PPARy no metabolismo de glicose e na sensibilização da insulina, o presente trabalho justificase como um esforço para avançar na compreensão da interação entre ligantes sintéticos com o receptor PPARy e a proposição de moléculas mais seguras e mais eficazes para a manutenção de níveis euglicêmicos. Foi realizada a expressão, a purificação, seguida de estudos cristalográficos em cinco ligantes selecionados a partir de etapas de docking realizados anteriormente pelo nosso grupo de Biotecnologia Molecular do Instituto de Física de São Carlos. Os ensaios de cristalização do PPARY complexado a ligantes sintéticos resultaram em duas estruturas cristalográficas que apresentaram uma conformação em que os ligantes não interagiram diretamente na hélice 12 como descritos para agonistas totais do PPARy, adotando características de agonistas parciais. Esses ligantes apresentaram interações hidrofóbicas que estabilizam as fitas- $\beta$. Este conjunto de informações estruturais apresentados neste trabalho para o PPARY proporcionou um 
entendimento das interações que esse receptor é capaz de fazer na presença de um ligante, além de que poderão ser úteis no desenvolvimento de novos moduladores seletivos do PPARy semelhante ao que já se encontram no mercado, porém com efeitos colaterais reduzidos.

Palavras-chave: Receptores nucleares. Receptor ativador da proliferação de peroxissomos. Agonista parcial. 


\section{ABSTRACT}

PAULA, K. de. Structural studies of new synthetic ligands of the PPARY receptor. 2017. 104 p. Tese (Doutorado em Ciências) - Instituto de Física de São Carlos, Universidade de São Paulo, São Carlos, 2017.

Nuclear receptors comprise a superfamily of structurally-related regulated intracellular proteins capable of recognizing specific DNA sequences and regulating the transcription of target genes responding to metabolic signals, hormones and other regulatory molecules integrating many signaling pathways. Peroxisome proliferator-activating receptors (PPARs) are nuclear receptors that govern the transcription of several genes involved primarily in fatty acid and energy metabolism. Activation of PPARY has a broad aspect of biological functions, regulating metabolism, reducing inflammation, influencing immune cell balance, inhibiting apoptosis and oxidative stress, and improving endothelial function. These effects appear to be beneficial not only in diabetes and atherosclerosis, but also in several other conditions. PPARy agonists are used as insulin sensitizers for the treatment of diabetes II, being a molecular target of the thiazolidinediones drugs. A number of severe side effects associated with the use of drugs of this class and the importance of PPARY in glucose metabolism and insulin sensitization, the present work is justified as an effort to advance the understanding of the interaction between synthetic ligands with the PPARy receptor and proposing safer and more effective molecules for the maintenance of euglycemic levels. The expression, purification, followed by crystallographic studies in five ligands selected from docking steps previously performed by our Molecular Biotechnology group of the Physics Institute of São Carlos. The crystallization assays of PPARy complexed to synthetic ligands resulted in two crystallographic structures that exhibited a conformation in which the ligands did not interact directly in helix 12 as described for total PPARy agonists, adopting characteristics of partial agonists. These ligands showed hydrophobic interactions that stabilize the $\beta$-ribbons. This set of structural information presented in this work for the PPARy was of great value for the understanding of the interactions that this receptor is able to make in the presence of a ligand, besides that they could be useful in the development of new selective modulators of the PPARy similar to that are already on the market, but with reduced side effects. 
Keywords: Nuclear receptors. Receptor activator of peroxisome proliferation. Partial agonist. 


\section{LISTA DE FIGURAS}

Figura 1 - Organização estrutural de receptores nucleares. Incluindo o N-terminal, DBD em lilás, a hinge em verde, o LBD em vermelho. O modelo corresponde à estrutura do PPARy LBD. A estrutura representa o PDB 3DZY, que corresponde ao receptor PPARY complexado com o receptor ácido retinóico $(\mathrm{RXR})$ que está representado em branco e o coativador em amarelo

Figura 2 - Estados oligoméricos de receptores nucleares e a interação com os HREs. Receptor órfão monomérico que se liga a um sítio simples. Sequências palíndromicas e formação de heterodímeros do RXR.

Figura 3 - Enovelamento tridimensional do domínio de ligação ao ligante de PPARs. Representação em cartoon, com as 13 hélices do LBD em formato de cilindro, organizadas em camadas sobrepostas que formam o LBD. Essa nomenclatura da estrutura secundária foi baseada na estrutura do

PPARY

(PDB 2PRG)....

Figura 4 - Estados conformacionais do domínio de ligação ao ligante. A. Está representada a forma apo, com a H12 na conformação inativa. B. Está mostrando a H12 na conformação ativa na forma holo. Em ambas as estruturas a H12 está representada em lilás.

Figura 5 - $\quad$ Estrutura tridimensional do PPARY-LBD mostrando o volume do seu bolsão de ligação, região que na maioria das vezes ocorre à interação com os ligantes.

Figura 6 - $\quad$ Bolsão de ligação do PPARY-LBD em formato de "Y", composto por três braços. O braço I representado em magenta inclui a $\mathrm{H} 12$ e resíduos polares. O braço II está representado em ciano e o braço III em verde situados no interior da entrada o sítio ativo, são menos conservados e hidrofóbicos

Figura 7 - Regulação metabólica dos PPARs. As três isoformas regulam a homeostase de lipídios e glicose através de suas atividades coordenadas no fígado, músculo e tecido adiposo

Figura 8 - $\quad$ Ativação transcricional do PPARY. (1) Ligação dos ligantes de ativação do PPARy e do RXR; (2) após a ligação do ligante há uma mudança conformacional dos receptores, resultando em uma reorganização do complexo transcricional e alterações nos cofatores transcricionais associados; (3) resultante desta reorganização, o complexo transcricional é ativado e se inicia a mudança na expressão dos genes alvo do PPARY

Figura 9 - Estrutura química das tiazolidinadionas (TZDs)..................................... 
Figura 10 - Estrutura tridimensional do PPARy mostrando na região do bolsão de ligação agonistas totais e parciais. Em A está representado o agonista total do PPARy a TZD roziglitasona, nela pode-se notar que o ligante está próximo a $\mathrm{H} 12$, diferente do que está representado em b, c e d onde os agonistas parciais INT131, MRL24 e GQ16 não estão interagindo diretamente com a H12 através de interações hidrofóbicas. Em todas as estruturas a H12 está mostrada com linhas tracejadas em vermelho.

Figura 11 - Estrutura química dos ligantes selecionados a partir do docking.

Figura 12 - Esquema para cristalização de proteínas. Em A, está ilustrado o método de gota pendurada hanging drop. Nesse método a gota fica pendurada em uma lâmina siliconizada, quando o equilíbrio é atingido os cristais começam a crescer na gota. Em B, pode-se visualizar o diagrama de fases para uma condição de cristalização, o diagrama é dividido em quatro zonas: zona insaturada, zona metaestável, nucleação e precipitado.

Figura 13 - Gel de poliacrilamida 15\%indicando a expressão em larga escala e purificação do domínio LBD do receptor PPARY de origem humana. Poço 1- marcador de peso molecular; 2-meio induzido; 3-produto não ligado a matriz 1 (flow through), 4- flow through 2; 5-tampão de lavagem sem imidazol; 6-tampão de lavagem + 5mM de imidazol; 7tampão de lavagem + 10mM de imidazol; 8-tampão de lavagem + 20mM de imidazol; 9-tampão de lavagem + 40mM de imidazol e 10tampão de lavagem $+200 \mathrm{mM}$ de imidazol.

Figura 14 - Perfil cromatográfico do PPARy LBD após a purificação por afinidade, as frações referentes ao pico de PPARy foram coletadas, concentradas e analisadas por SDS-PAGE $15 \%$.

Figura 15 - Estrutura química do complexo 3, em vermelho evidenciando o grupo tetrazol.

Figura 16 - A. Cristais do complexo 3 crescido na condição de 0,9 M de citrato de sódio, $100 \mathrm{mM}$ de Tris- $\mathrm{HCl} \mathrm{pH}$ 7,0. B. Padrão de difração do PPARY em complexo com o ligante 3 com difração a $2,2 \AA$.

Figura 17 - $\quad$ Representação do dímero do PPARy-LBD complexada com o ligante 3. As hélices- $\alpha$ da cadeia $A$ estão representadas em lilás e as da cadeia $B$ em rosa, as $\mathrm{H} 12$ estão representadas em ciano, o ligante está representado em verde e sticks.

Figura 18 - Nesta figura está evidenciado o omit map do ligante 3 em $2 F o-F c$, o contorno mostrado para o ligante é de $1,0 \sigma$. Em linhas tracejadas está mostrando as ligações de hidrogênio com suas respectivas distâncias...

Figura 19 - Detalhes estruturais do complexo PPARY-LBD com o ligante 3 na conformação inativa (cadeia B), as linhas tracejadas em amarela indicam as ligações de hidrogênio.................................................................................... 70

Figura 20 - Padrão das interações da rosiglitazona (PDB:2PRG) ......................... 71 
Figura 21 - Sobreposição da estrutura do PPARY complexado com o ligante 3 (dourado) e do PPARy complexado com a rosiglitazona (pink) .....

Figura 22 - Sobreposição do complexo 3 em dourado com o agonista parcial MRL24 em azul (2Q5P).

Figura 23 - Distribuição dos fatores de temperatura da cadeia $A$ e da cadeia $B$ do complexo 3. A $\mathrm{H} 12$ está representada em linhas tracejadas em vermelho

Figura 24 - Distribuição dos fatores de temperatura do agonista total rosiglitazona, do complexo 3 e do agonista parcial MEKT76 que apresenta no seu refinamento uma resolução de 2,2 Å o mesmo que o complexo 3. Para todas as estruturas tridimensionais estão mostradas as cadeias $B$...

Figura 25 - Ensaio de diferenciação das células 3T3-LI com o complexo 3. A. mostra as células 3T3-LI antes da diferenciação na presença da solução de diferenciação (insulina, dexametasona e IBMX), os préadipócitos atingiram a morfologia de adipócitos maduros com características primárias, incluindo um grande número de gotículas lipídicas citoplasmáticas. A coloração com Oil Red O evidenciou as gotículas lipídicas com marcação vermelha. Em B as células com concentrações diferentes do complexo 3 e rosiglitazona.

Figura 26 - Cristais obtidos do PPARy com o complexo 4

Figura 27 - A. Estrutura do PPARy com o complexo 4. A cadeia A está representada em ciano e a cadeia $B$ em rosa, as $\mathrm{H} 12$ estão em destaque

Figura 28 - $\quad$ Figura 28 - Interações entre o ligante 4 e o receptor PPARy. As ligações de hidrogênio estão representadas em linhas tracejadas em preto

Figura 29 - Sobreposição do complexo 4 com o agonista total rosiglitazona. B. Sobreposição do complexo $4 \mathrm{com}$ agonistas parciais MRL24 (PDB 2Q5P), INT131 (PDB 3FUR), GQ16 em amarelo (PDB 3T03), amorfrutina I (PDB 4A4V) e amorfrutina II (PDB 4A4W)

Figura 30 - Sobreposição do complexo 3 em lilás e do complexo 4 em dourado, em ambos a H12 está representada em rosa. Ao lado está em evidência a conformação dos ligantes.

Figura 31 - Distribuição dos fatores de temperatura da cadeia $A$ e da cadeia $B$ do complexo 4. A H12 está representada em linhas tracejadas em vermelho.

Figura 32 - Estrutura química de compostos tetrazóis publicado na patente por Kenneth e colaboradores. 



\section{LISTA DE ABREVIATURAS E SIGLAS}

$\mathrm{AF}-1$

AR

CDK5

DMSO

DBD

DM

DTT

ER

FDA

GR

HRE

IPTG

LBD

LBP

MM

MR

PDB

PMSF

PPAR

PPRE

PR

RAR

RNs

$\mathrm{RXR}$

SM

APPARYMs

TR

$\mathrm{TN}-\alpha$

Tris- $\mathrm{HCl}$

TZD

VDR
Função de ativação (Activation Function)

Receptor de Andrógeno

Quinase dependente da ciclina 5

Dimetilsulfóxido

Domínio de Ligação ao DNA (DNA Ligand Domain)

Diabetes mellitus

Ditiotreitol

Receptor de Estrógeno

Food and Drug Administration

Receptor de Glicocorticóide

Elementos Responsivos (Hormone Responsive Elements)

Isopropil- $\beta$-D-1-tiogalactopiranosídeo

Domínio de Ligação ao Ligante (Ligand Binding Domain)

Bolso de Ligação do Ligante (Ligand Binding Pocket)

Marcador Molecular

Receptor Mineralocorticoide

Banco de Dados de Proteína (Protein Data Bank)

Fluoreto de Fenilmetilsulfonil

Receptor Ativador da Proliferação de Peroxissomos

Elementos Responsivos aos PPARs

Receptor da Progesterona

Receptor de Ácido Retinóico

Receptores Nucleares

Receptor X Retinóide

Síndrome Metabólica

Moduladores Seletivos do PPARY

Receptor do Hormônio Tireoidiano

Fator de Necrose Tumoral- $\alpha$

Hidroximetil aminometano (Tris-Hydrochloride)

Tiazolidinadionas

Receptor de Vitamina D 



\section{Sumário}

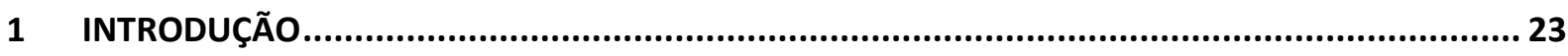

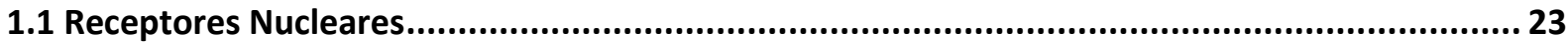

1.20 bolsão de ligação ......................................................................................................... 28

1.3 Receptores ativadores da proliferação de peroxissomos - PPARs ........................................ 31

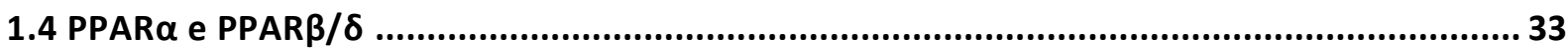

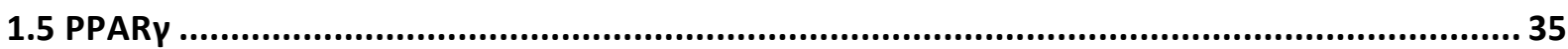

1.6 Ligantes naturais e sintéticos do PPAR

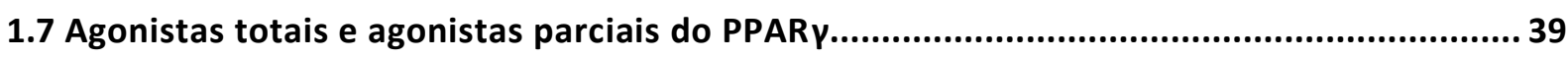

1.8 PPARY em doenças associadas ao risco cardiovascular ........................................................ 42

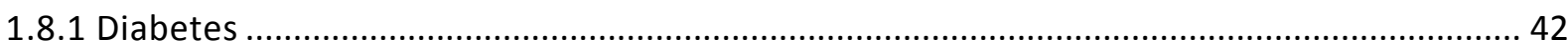

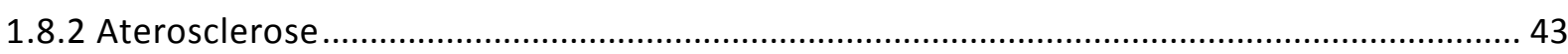

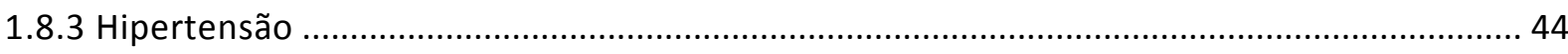

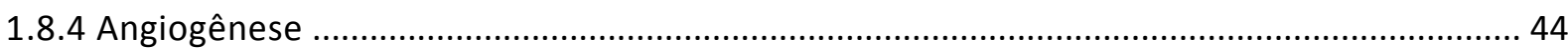

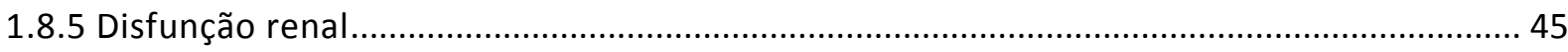

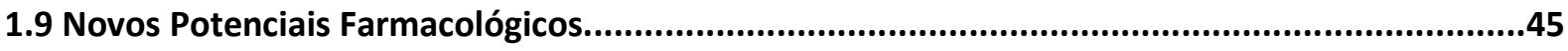

2 OBJETIVOS E JUSTIFICATIVA.......................................................................................... 49

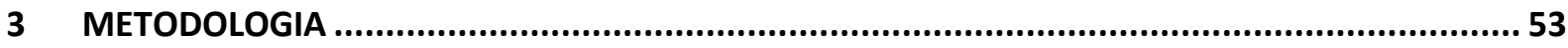

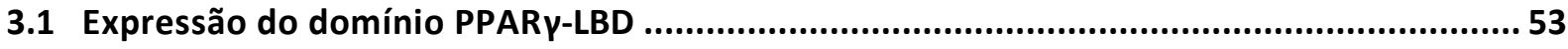

3.2 Purificação do PPARY-LBD por cromatografia de afinidade ................................................... 53

3.3 Purificação por cromatografia por exclusão de tamanho …………………………………..... 54

3.4 Seleção dos ligantes ..................................................................................................... 54

3.5 Ensaios de cristalização do PPARy com os ligantes sintéticos ................................................ 56

3.6 Coleta e processamento dos dados de difração de raios-x ………………………………....... 59

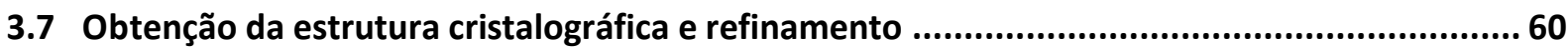

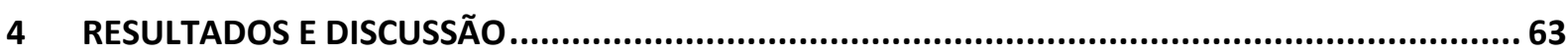

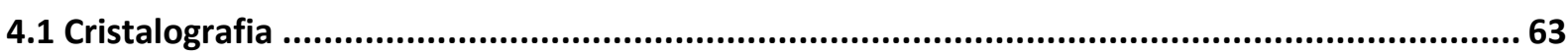

4.1.1 Expressão e purificação do domínio LBD do PPARY ……………………………………....... 63

4.2 Análises Estruturais do PPARY-LBD em Complexo com o ligante 3 .............................................. 64

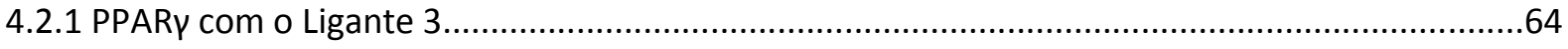

4.2.2 Testes de cristalização, coleta e processamento dos dados do PPARy com o Complexo 3.........65

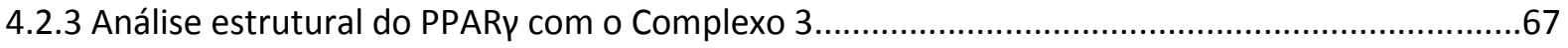

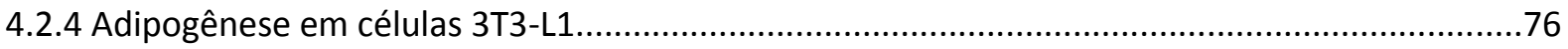

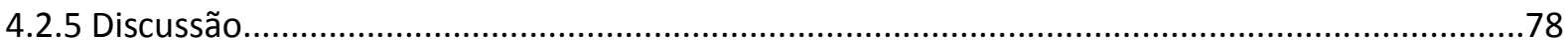




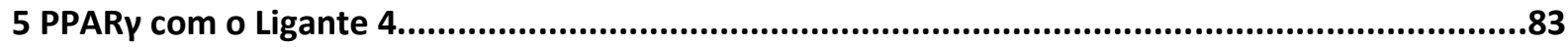

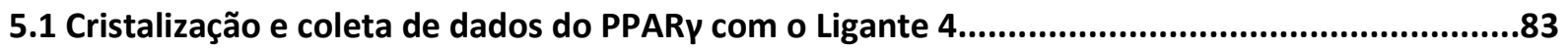

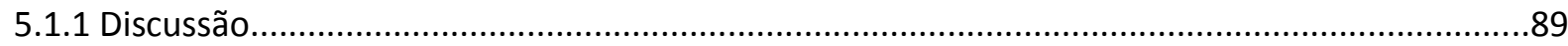

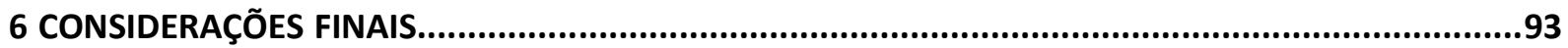

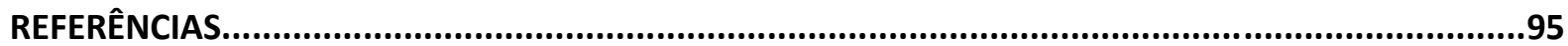




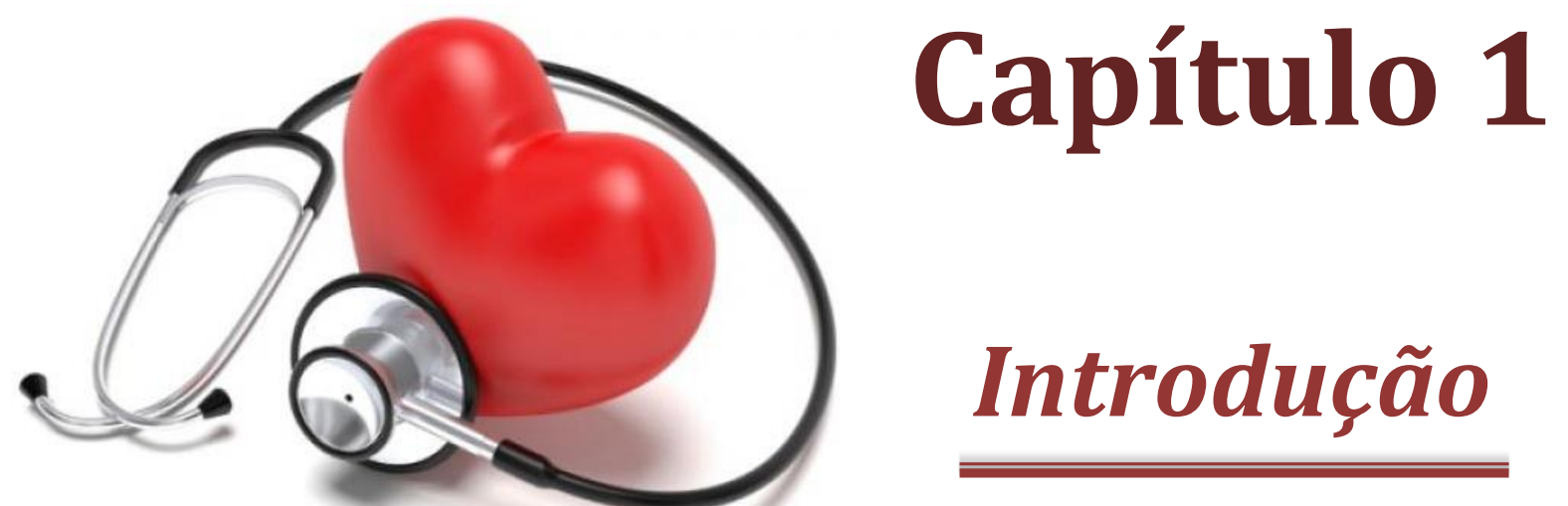





\section{INTRODUÇÃO}

\subsection{Receptores Nucleares}

Os Receptores Nucleares (RNs) representam uma das classes mais importantes de receptores envolvidos na sinalização intracelular, pois regulam a expressão gênica relacionada a processos metabólicos essenciais. Eles agem através da regulação da transcrição de genes-alvo respondendo a sinais metabólicos, hormônios e outras moléculas regulatórias integrando muitas vias de sinalização. ${ }^{1-2}$ Existem 48 genes que codificam os RNs no genoma humano, ${ }^{3,4}$ e as proteínas desta superfamília adotam estruturas modulares de 50-100 kDa e estão envolvidas em praticamente todas as funções fisiológicas do organismo, incluindo regulação do metabolismo, homeostase, divisão e diferenciação celular. ${ }^{4-7}$

Os RNs têm sido considerados alvos para novas terapias farmacológicas e têm atraído muita atenção devido à sua importância na regulação dos processos metabólicos, influenciando tanto o metabolismo de lipídios como o metabolismo de glicose..$^{8-11}$ Por esse motivo, os agonistas e antagonistas que atuam nesses receptores são objetos de estudo importantes para o desenvolvimento de novos medicamentos, devido ao fato dos receptores estarem relacionados diretamente em diversas doenças humanas dentre elas: obesidade, alguns tipos de câncer, diabetes, osteoporose, doenças metabólicas, doenças endócrinas, arteriosclerose, psoríase, acne, hipercolesterêmica e desordem lipídica. Sendo assim considerados alvos para novas alternativas de tratamento. ${ }^{3,5}$

Os RNs são formados por 5-6 regiões conservadas (Figura 1), que codificam funções específicas e apresentam quatro domínios típicos. Um domínio N-terminal que contém um de domínio de ativação AF-1 (Activation Function 1), com estrutura desconhecida, mas provavelmente desordenada. Essa região possui a função de ativação na ausência do ligante. .,5-6 $^{3}$

O domínio de ligação ao DNA (DNA binding domain, DBD), é constituído por aproximadamente 70 resíduos de aminoácidos, revelando um domínio estruturado na forma de dois dedos de zinco (Zn-I e Zn-II). O DBD é estruturalmente composto por hélices- $\alpha$, a primeira hélice se encaixa no sulco maior da sequência de DNA reconhecida, interagindo com bases específicas e começa na terceira cisteína 
conservada (hélice de reconhecimento). A segunda hélice forma um ângulo reto com a primeira hélice e fica próxima ao C-terminal do segundo dedo de zinco. ${ }^{1,4,6}$

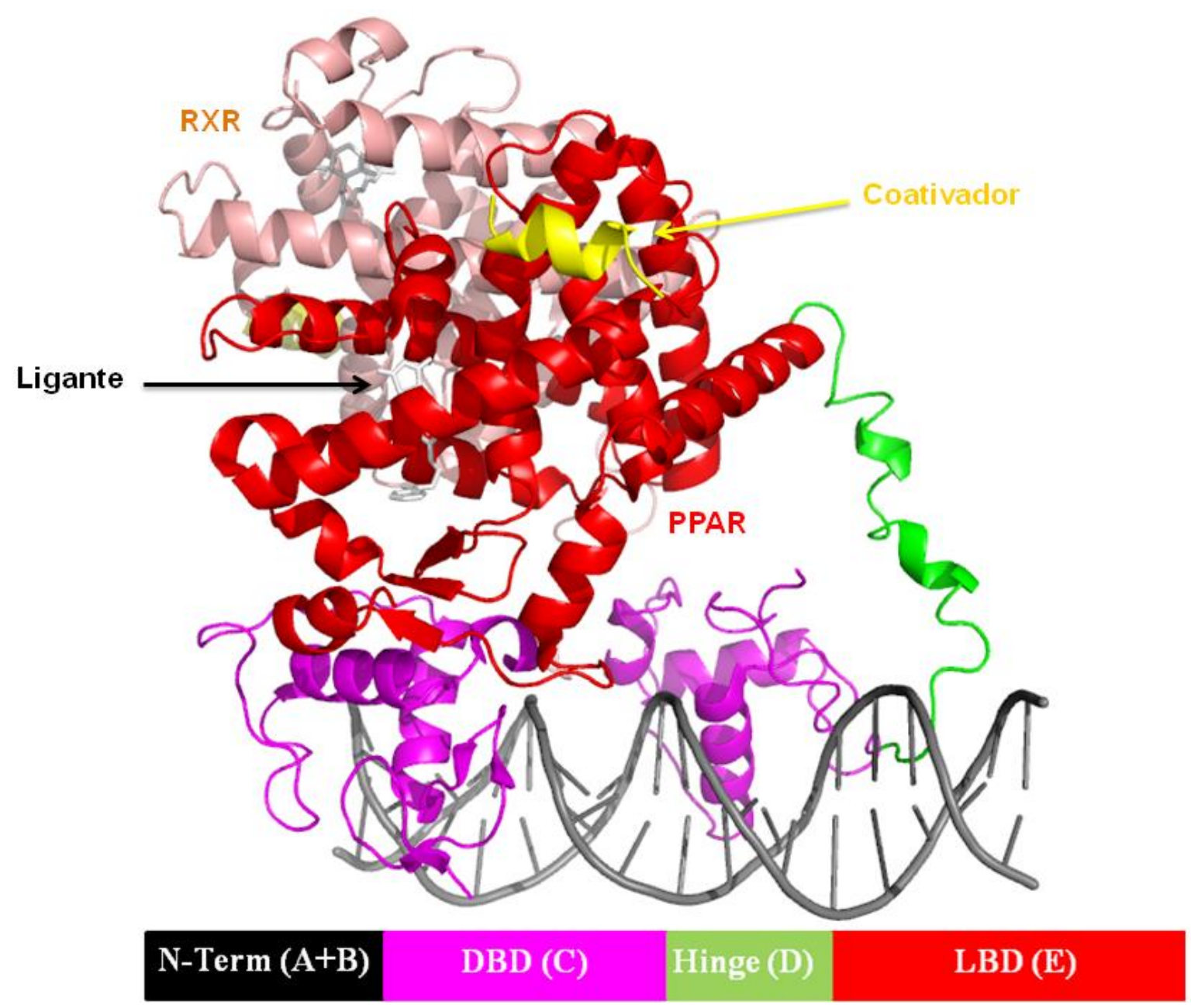

Figura 1 - Organização estrutural de receptores nucleares. Incluindo o N-terminal, DBD em lilás, a hinge em verde, o LBD em vermelho. O modelo corresponde à estrutura do PPARy LBD. A estrutura representa o PDB 3DZY, que corresponde ao receptor PPARy complexado com o receptor ácido retinóico $(\mathrm{RXR})$ que está representado em branco e o coativador em amarelo.

Fonte: Elaborada pela autora.

Os RNs se ligam via $\mathrm{DBD}$ aos elementos responsivos (hormone responsive elements, HRE), ${ }^{1}$ derivados do motivo AGGTCA, na maioria das vezes os RNs se ligam como dímeros à duas cópias desse motivo. Essa ligação pode ocorrer de três maneiras e a forma como estes receptores se ligam está relacionado ao seu estado de oligomerização (Figura 2), ${ }^{2,10}$ A primeira é caracterizada pela formação monomérica, quando se liga a um sítio simples. Ex: alguns receptores órfãos como o NGFI - Nerve Growth Factor-Induced. A segunda maneira é homodimérica, quando se liga a sítios duplicados com formato de palíndromo ou palíndromo invertido. Ex: 
receptores de estrógeno (ER), hormônio tiroidiano (TR), glicocorticóide (GR), progesterona (PR), receptor de andrógeno $(A R)$ e receptor $X$ retinóide (RXR). A terceira é heterodimérica, quando se liga a sítios duplicados com repetição direta. Ex: heterodímeros com RXR. ${ }^{7-11}$
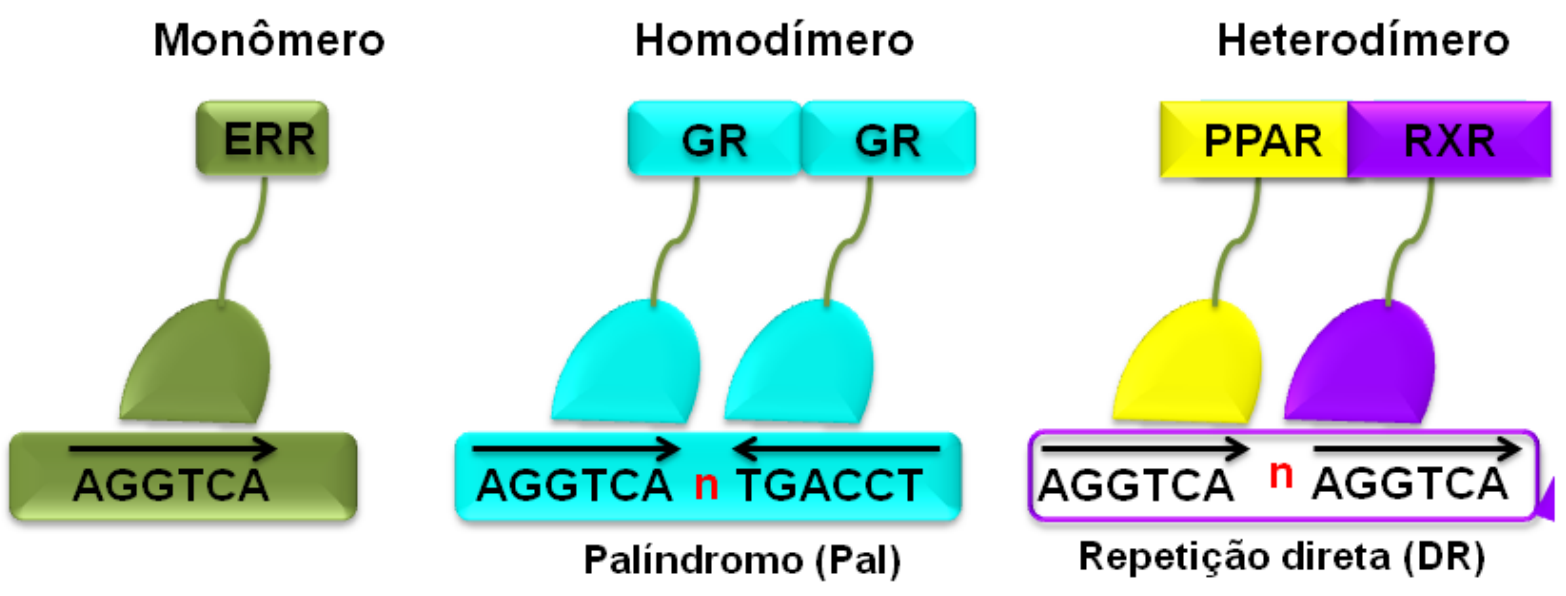

Figura 2 - Estados oligoméricos de receptores nucleares e a interação com os HREs. Receptor órfão monomérico que se liga a um sítio simples. Sequências palíndromicas e formação de heterodímeros do RXR.

Fonte: Elaborada pela autora.

O domínio de articulação (hinge) que liga o domínio de ligação de DNA central e o domínio C-terminal. Esta região é conhecida como dobradiça, pois permite que o DNA e os domínios de ligação aos ligantes adotem diferentes conformações sem impedimentos estéricos. ${ }^{2-6,8}$ A hinge também é capaz de promover a interação dos correpressores com o receptor. ${ }^{11}$

O domínio C-terminal também chamado domínio de ligação ao ligante (ligand binding domain, LBD), que é considerado a principal porção estrutural de um receptor nuclear. ${ }^{4}$ Essa região é responsável por uma variedade de funções reguladas pela ligação do hormônio, tais como: servir de interface de dimerização com outros receptores e ligação de antagonistas e agonistas promovendo ou bloqueando a transcrição. Este domínio possui a função de transativação 2 (activation function-2, AF-2), ou função de ativação dependente do ligante. O enovelamento geral para o LBD ( 280 aminoácidos) está estruturado como um sanduíche de três camadas de hélices- $\alpha$ e mais quatro pequenas fitas- $\beta$ formando um $\beta$-hairpin. ${ }^{10-13}$ 
Este domínio contém 12 hélices- $\alpha$ enumeradas de $\mathrm{H} 1$ a H12 e a organização terciária destas hélices forma uma cavidade hidrofóbica que acomoda o ligante, o bolsão de ligação (ligand binding pocket, LBP). Estas hélices podem ser visualizadas na Figura 3 e servem como âncoras para proteínas de ligação e também para o reconhecimento de ligantes. As hélices 3 e 12 formam uma superfície polar, que reconhece as proteínas coativadoras enquanto hélices $3,5,10$ e 12 formam 0 bolsão de ligação enterrado na estrutura. A hélice 10 também serve como superfície de dimerização. ${ }^{11}$

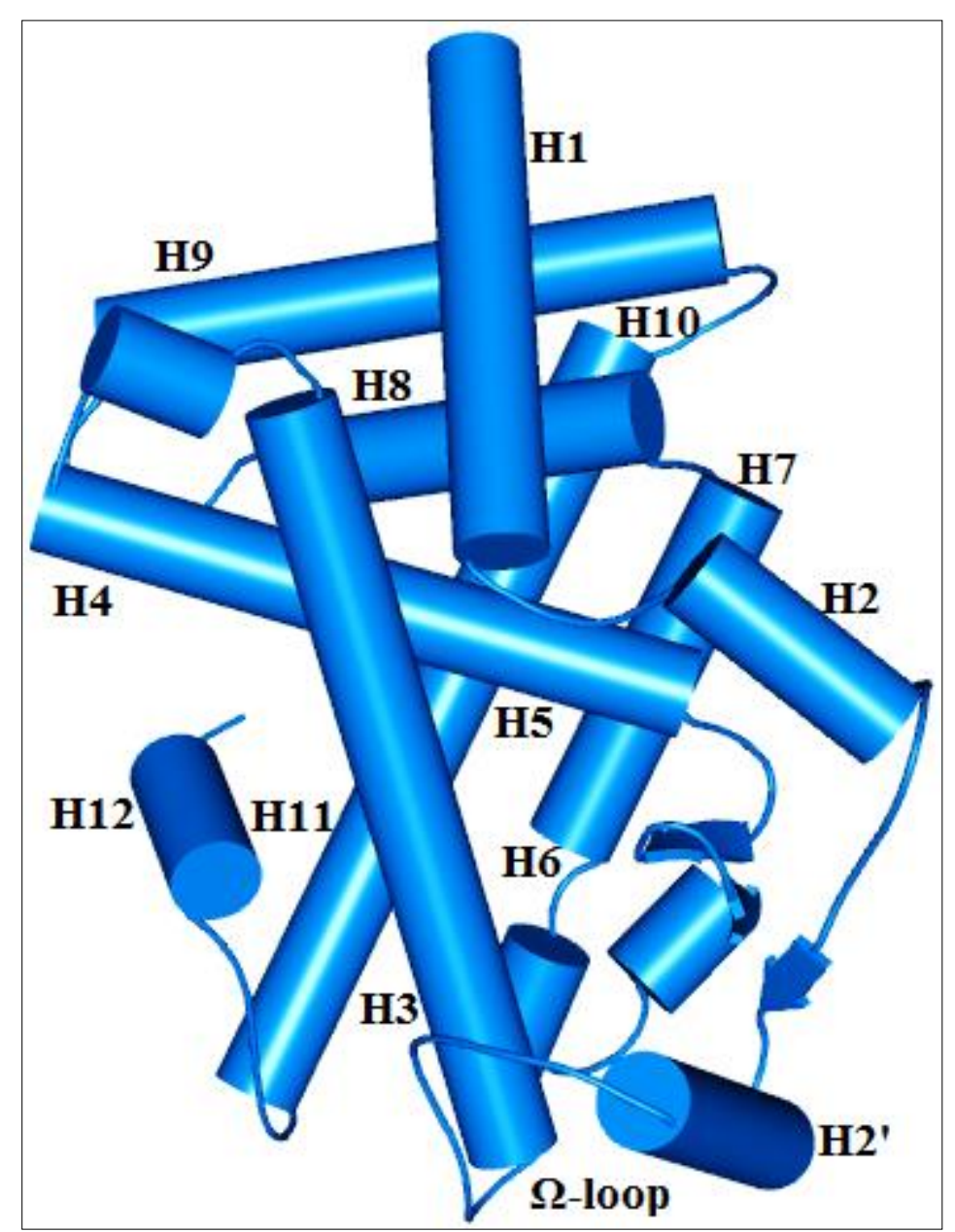

Figura 3 - Enovelamento tridimensional do domínio de ligação ao ligante de PPARs. Representação em cartoon, com as 13 hélices do LBD em formato de cilindro, organizadas em camadas sobrepostas que formam o LBD. Essa nomenclatura da estrutura secundária foi baseada na estrutura do PPARY (PDB 2PRG).

Fonte: Elaborada pela autora.

Classicamente descreve-se a hélice 12 como um componente estrutural de vital importância no mecanismo da ativação da transcrição. Após a interação com o ligante ocorre uma mudança conformacional da proteína provendo um novo padrão 
de ligações que proporcionam uma superfície adequada para a ligação dos coativadores. ${ }^{12}$ Esse mecanismo envolve basicamente a abertura e o fechamento da hélice C-terminal H12 para a entrada e posteriormente a acomodação do ligante, sendo chamado de "mecanismo ratoeira" (mouse trap), por lembrar o funcionamento de ratoeira. ${ }^{9}$

$\mathrm{Na}$ ausência de ligantes, ou seja, na forma livre os receptores são considerados na forma apo, nessa forma a $\mathrm{H} 12$ afasta-se do LBD, adotando uma conformação estendida (Figura 4A), chamada de conformação aberta, sendo considerada a conformação inativa dos RNs. As hélices $\mathrm{H} 11$ e $\mathrm{H} 10$ são descontínuas. Quando ocorre a presença de ligantes os receptores são referidos na forma holo, e as hélices $\mathrm{H} 10$ e $\mathrm{H} 11$ se tornam contínuas, estabilizando a $\mathrm{H} 12$ e fazendo com que a mesma mude sua conformação sendo dita como conformação fechada, representando o modelo ativo dos RNs (Figura 4B). ${ }^{3,12}$

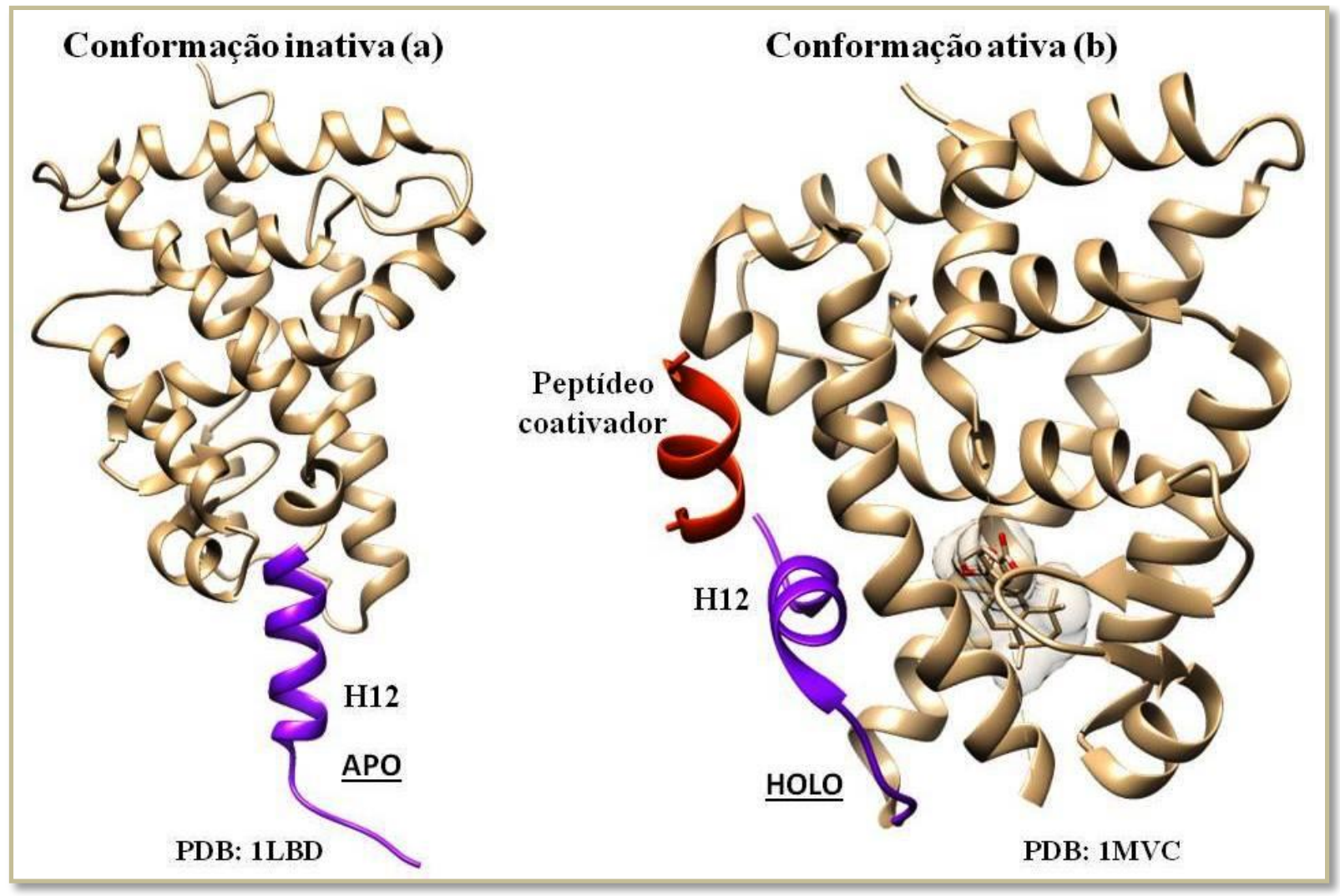

Figura 4 - Estados conformacionais do domínio de ligação ao ligante. A. Está representada a forma apo, com a H12 na conformação inativa. B. Está mostrando a H12 na conformação ativa na forma holo. Em ambas as estruturas a H12 está representada em lilás.

Fonte: Elaborada pela autora. 
No caso do PPAR (Receptores ativadores da proliferação de peroxissomos) há uma hélice 2' adicional, e a região entre ela e a H3 corresponde ao $\Omega$ loop, que é uma porção bastante móvel do receptor que participa de mudanças conformacionais que ocorrem durante a ligação do ligante, e possuem também 2 fitas- $\beta$. Estas hélices estão organizadas como três camadas empilhadas, que caracteriza um enovelamento tipo sanduíche de hélices $\alpha$ (Figura 3$).{ }^{13}$

\subsection{0 bolsão de ligação}

Na família dos receptores nucleares, o domínio LDB é conservado entre seus membros, entretanto, apesar da semelhança estrutural, existem diferenças funcionais quanto à interação dos ligantes, sendo estes específicos. ${ }^{10-11} \mathrm{O}$ volume dos bolsões de ligação pode mudar de um membro da família para outro, sendo este volume uma característica inerente de cada um dos membros. O receptor de ácido retinóico RXR possui um bolsão com $420 \AA^{3}$, enquanto os PPARs têm os bolsões maiores, com volume de $1,300 \AA \AA^{3,12}$ e é uma cavidade hidrofóbica, quando comparado a outros RNs e o volume é de quase duas vezes maior (Figura 5). É importante salientar que alguns receptores podem adaptar o volume de bolsão de ligação ao ligante, tal como no caso do receptor da vitamina D (VDR). Este receptor pode reduzir o seu volume quando ligado ao seu ligante natural e expandir-se aguardando o agonista. ${ }^{14}$

Nos PPARs, o LBD é formado por resíduos hidrofóbicos e alguns resíduos carregados na região interna perto das fitas- $\beta$, que atuam como pontos de ancoragem para a região polar dos ligantes, o que confere a seletividade destes. $O$ LBD tem a capacidade de se adaptar ao ligante, reorganizando-se para a acepção de mais de um tipo de ligante, através da flexibilização das hélices $\mathrm{H} 3, \mathrm{H} 11, \mathrm{H} 12$ e do loop entre as hélices $\mathrm{H} 11$ e H12, que permite uma reorganização dos resíduos para a acepção dos ligantes. ${ }^{5,10-15}$ 


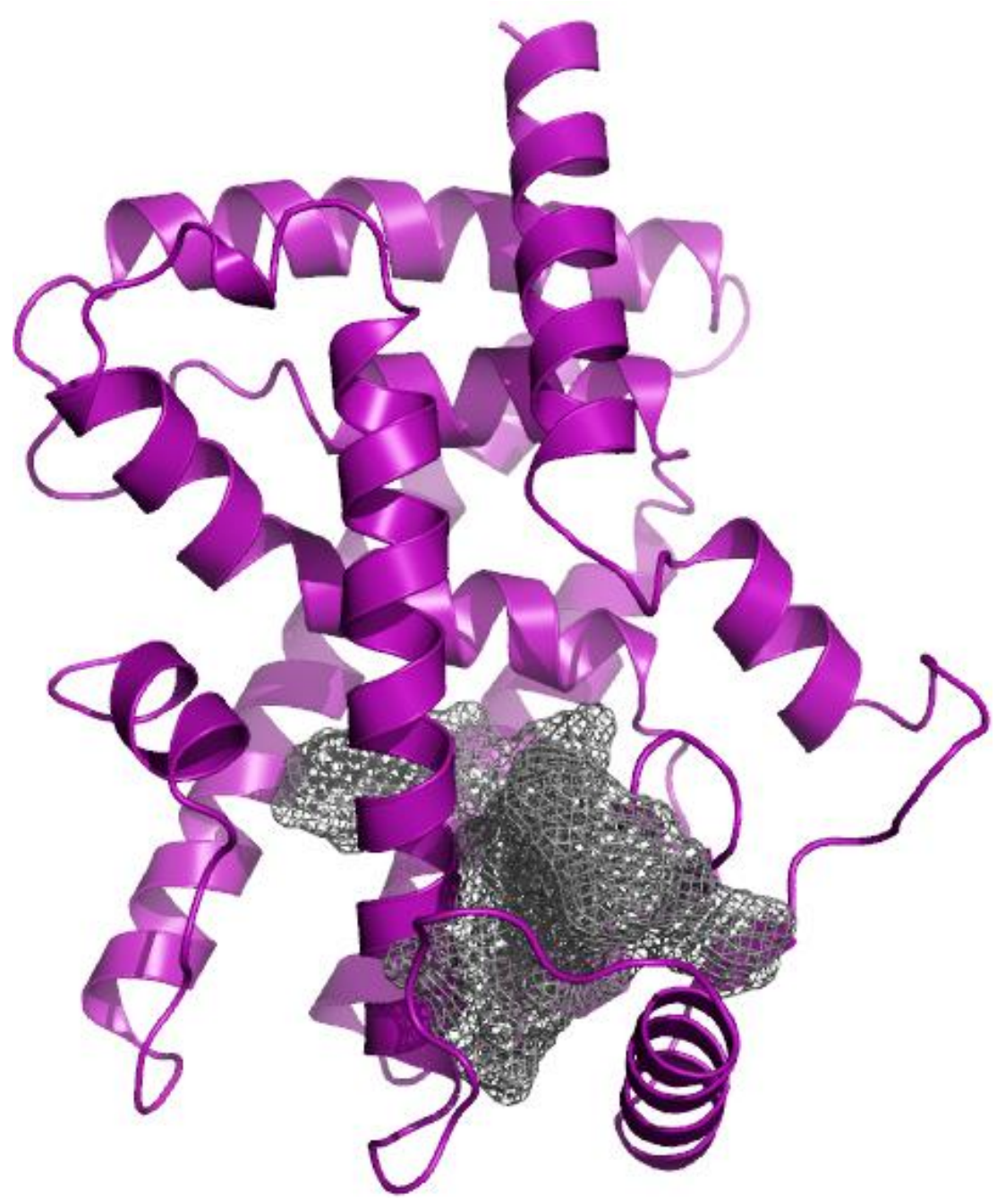

Figura 5 - Estrutura tridimensional do PPARY-LBD mostrando o volume do seu bolsão de ligação, região que na maioria das vezes ocorre à interação com os ligantes.

Fonte: Elaborada pela autora.

A ocupação dos ligantes dentro do bolsão de ligação pode ocasionar diferentes respostas transcricionais. A região do bolsão de ligação pode ser considerada como um bolsão em formato de "Y", composto por três sub-braços (Figura 6). Cada braço tem aproximadamente $12 \AA$ de comprimento.

O braço I é a única cavidade do PPARy substancialmente polar e inclui os resíduos próximos a $\mathrm{H} 12$. O braço II e III situados no interior da entrada do sítio ativo e entre as fitas- $\beta$ e a $H 3$, são predominantemente menos conservados e hidrofóbicos. ${ }^{15-17}$ É na $\mathrm{H} 12$ que os resíduos considerados cruciais para a função do AF-2 estão presentes. ${ }^{16-17} \mathrm{O}$ loop entre as hélices $\mathrm{H} 2$ 'e H3, situado na entrada do sítio de ligação, é muito flexível em todas as estruturas do PPAR e é desordenado em algumas estruturas. Isso sugere que a entrada do sítio de ligação pode se adaptar, permitindo que grandes ligantes entrem no bolsão de ligação sem alterar 
significativamente a estrutura geral do LBD. ${ }^{18,19}$ Trinta e quatro resíduos definem a parede da cavidade de ligação (Figura 5 ), cerca de $80 \%$ desses resíduos são conservados nos três isotipos. É interessante observar a conservação de quatro resíduos polares no braço I de cada isoforma do PPAR, sendo eles: serina 289 , histidina 323, histidina 449 e tirosina 473 para o PPARy, tirosina 289, histidina 323 e 449 e tirosina 473 do PPARß, e serina 280, tirosina 314, histidina 440 e tirosina 464 para o PPARa. Estes resíduos são parte de uma rede de ligações de hidrogênio que envolve o grupo carboxilato de ácidos graxos e ácidos eicosanóicos. ${ }^{20}$

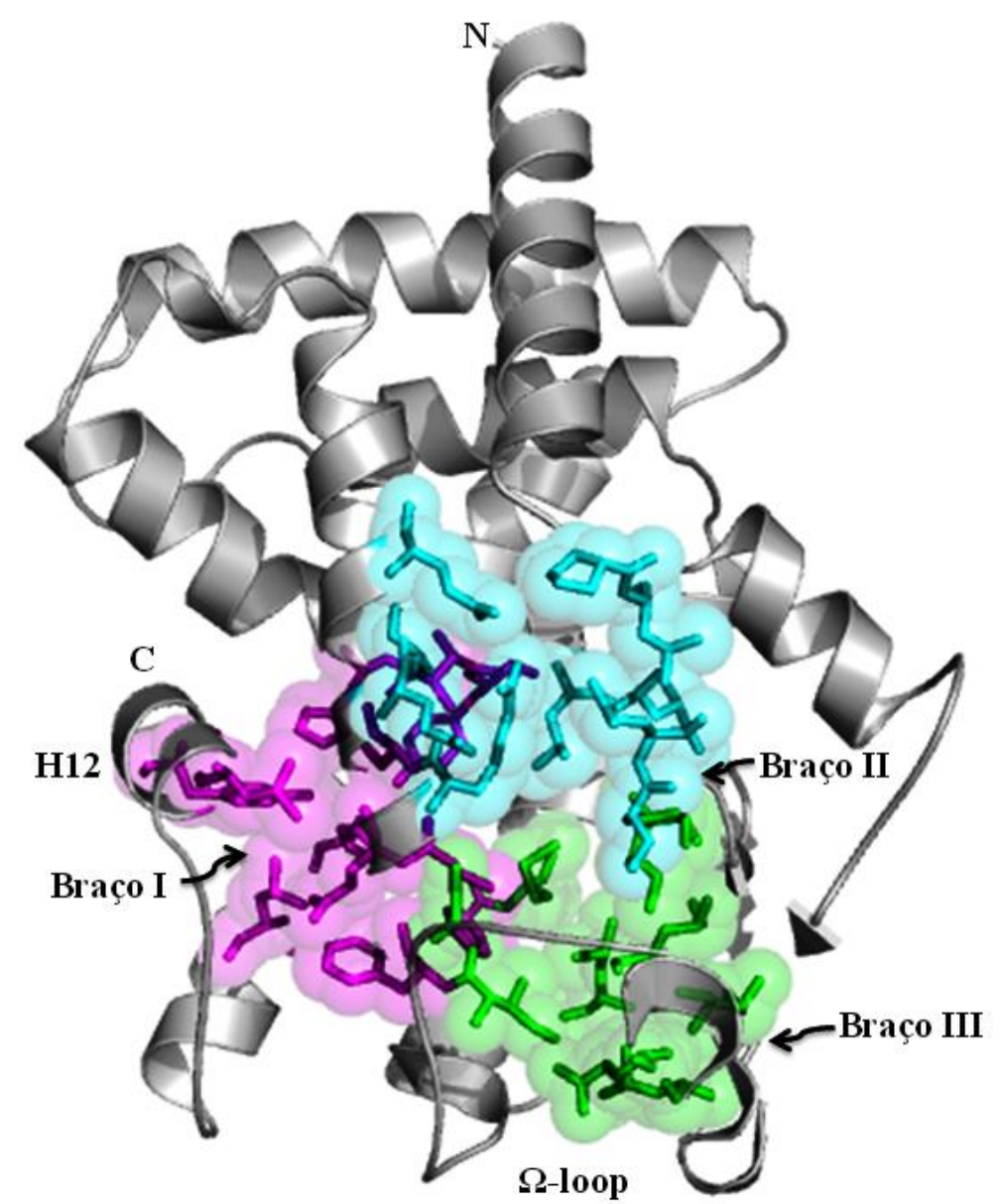

Figura 6 - Bolsão de ligação do PPARY-LBD em formato de "Y", composto por três braços. O braço I representado em magenta inclui a $\mathrm{H} 12$ e resíduos polares. O braço II está representado em ciano e o braço III em verde situados no interior da entrada o sítio ativo, são menos conservados e hidrofóbicos.

Fonte: Elaborada pela autora. 


\subsection{Receptores ativadores da proliferação de peroxissomos - PPARs}

Os PPARs são fatores de transcrição regulados por ligantes lipofílicos. Pertencentes à superfamília dos receptores nucleares, regulam a transcrição de genes relacionados ao metabolismo de lipídeos, controle de inflamação e produção de insulina. Além disso, esses receptores estão envolvidos em outros processos biológicos como o crescimento, desenvolvimento e apoptose celular em uma variedade de células. ${ }^{21}$

Foram descobertos em 1990 através da clonagem de um receptor órfão murino, onde causavam a proliferação de peroxissomos nesses roedores, por isso o nome. ${ }^{22}$ Seus ligantes, ácidos graxos, eicosanoides e prostaglandinas têm sido muito estudados no tratamento de diabetes e dislipidemias, sendo de grande importância para a indústria farmacêutica. ${ }^{15} \mathrm{O}$ potencial farmacológico dos RNs consiste, em parte, na habilidade de moléculas reproduzirem ou inibirem a atividade dos ligantes naturais. De fato, agonistas e antagonistas sintéticos de muitos receptores nucleares são constantemente usados no combate ao câncer em quimioterapias e em fármacos imunossupressores ou anti-inflamatórios. ${ }^{23-25}$

Em 1992 Dreyer e seus colaboradores clonaram e identificaram isotipos do PPAR, cada um codificado por um gene diferente, o PPARa (NR1C1), PPARß/ס (NR1C2) e o PPARy (NR1C3). ${ }^{26-27}$ Cada uma dessas isoformas são expressas em diferentes tecidos e em diferentes períodos de desenvolvimento celular de acordo com suas funções, no entanto a especificidade da ativação dos PPARs são dependentes do tipo celular. ${ }^{28}$ De acordo com seus perfis de expressão, os PPARs desempenham funções únicas na regulação do metabolismo energético (Figura 7). 


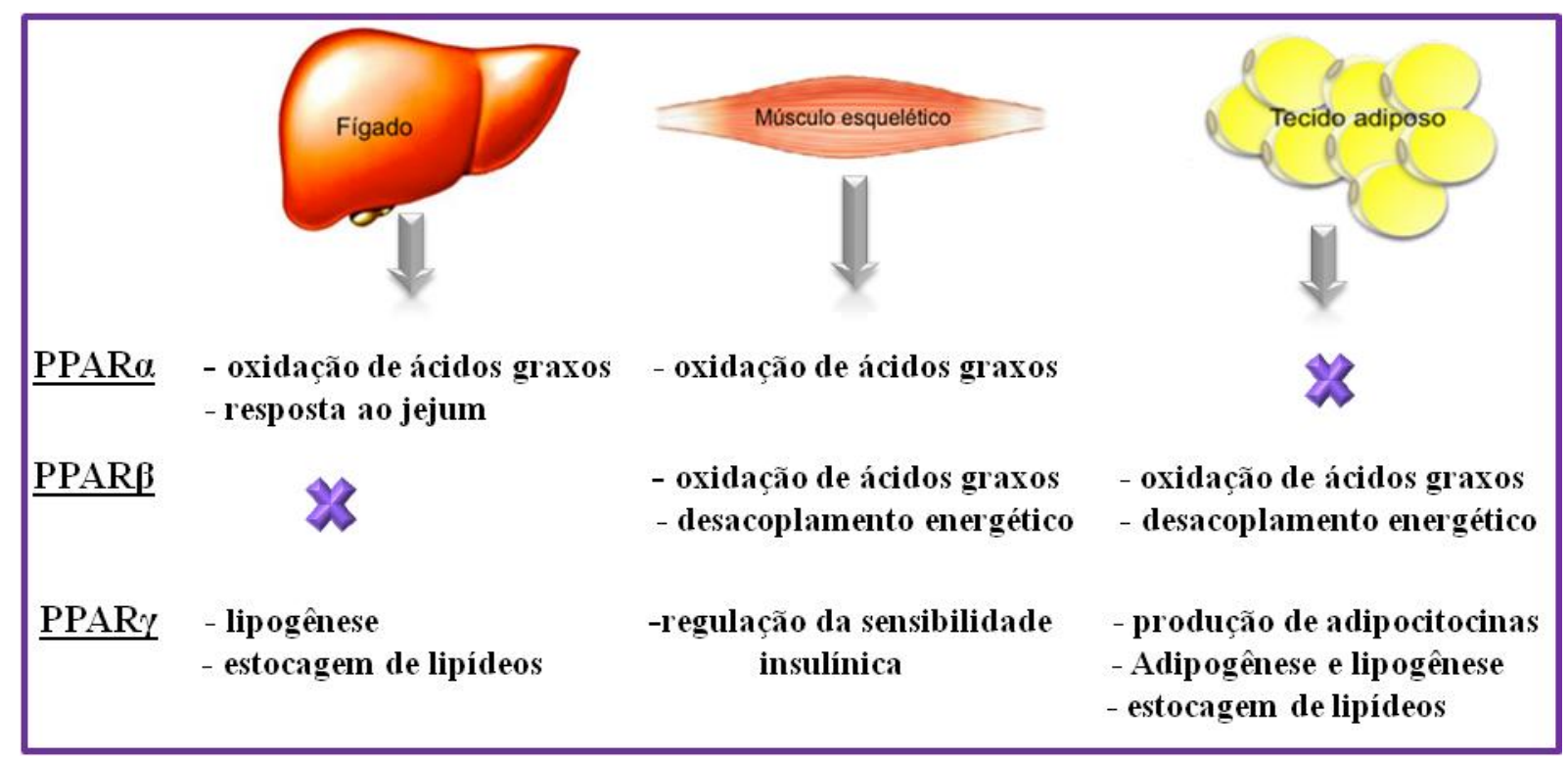

Figura 7 - Regulação metabólica dos PPARs. As três isoformas regulam a homeostase de lipídios e glicose através de suas atividades coordenadas no fígado, músculo e tecido adiposo.

Fonte: Adaptada de EVANS ${ }^{29}$

O processo de transcrição do gene é idêntico nos três subtipos. No interior do núcleo celular os PPARs na ausência de moléculas ativadoras, se encontram ligados aos correpressores. Quando ocorre a ligação com um ligante, os PPAR sofrem mudanças conformacionais que ocasionam 0 desligamento dos correpressores, e a formação do heterodímero funcional com o receptor RXR. O heterodímero reconhece sequências especificas no DNA (HRE), recrutando os coativadores e todo complexo proteico envolvido na maquinaria transcricional, que são capazes de modificar a estrutura da cromatina e iniciar o processo da transcrição de genes alvos (Figura 8)..$^{30-34}$ 


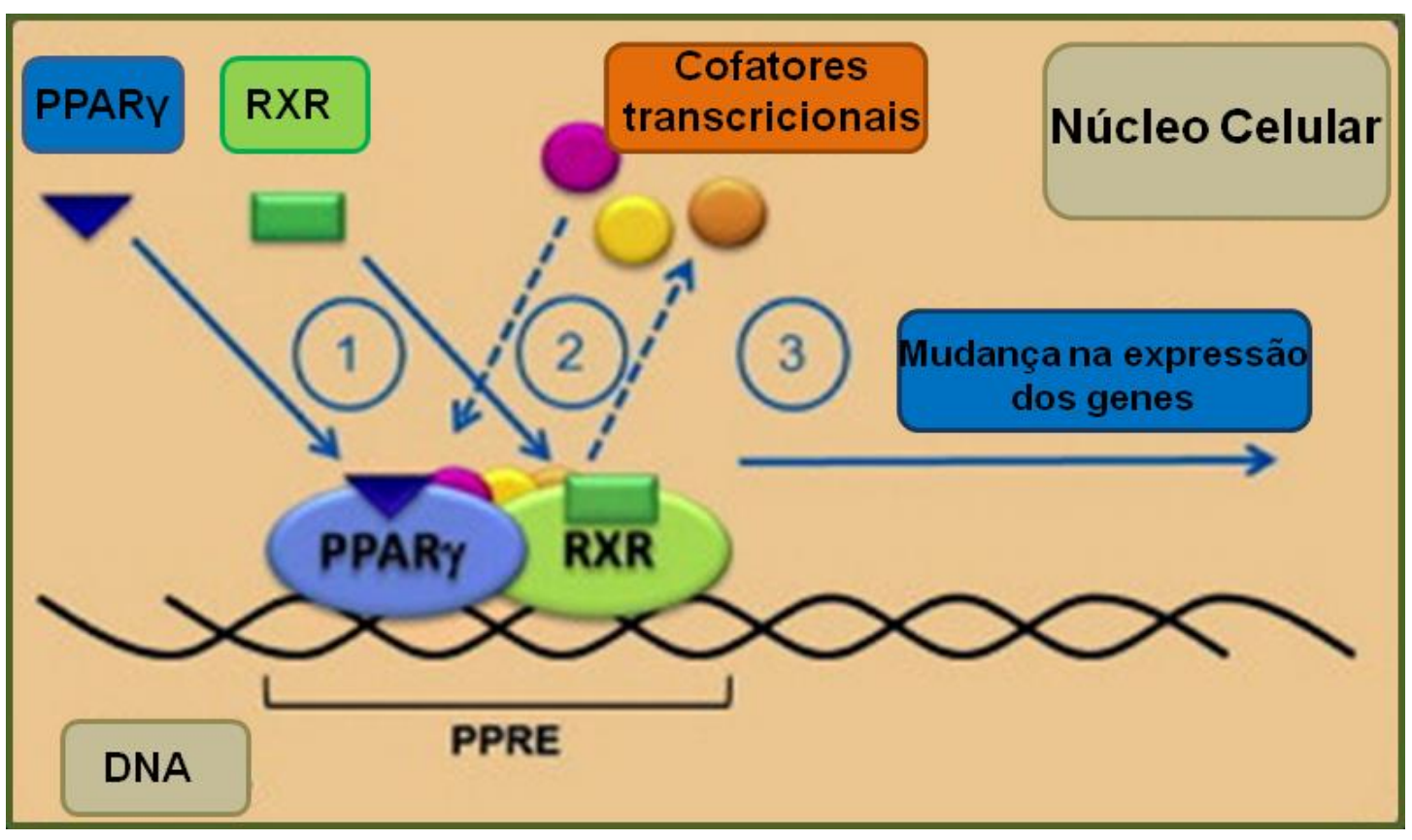

Figura 8 - Ativação transcricional do PPARy. (1) Ligação dos ligantes de ativação do PPARy e do RXR; (2) após a ligação do ligante há uma mudança conformacional dos receptores, resultando em uma reorganização do complexo transcricional e alterações nos cofatores transcricionais associados; (3) resultante desta reorganização, o complexo transcricional é ativado e se inicia a mudança na expressão dos genes alvo do PPARY

Fonte: Adaptada de WANG ${ }^{34}$

A primeira estrutura cristalina completa de um receptor foi resolvida em 2008 para o PPARy em complexo com RXR. ${ }^{35}$ Esta estrutura revelou, pela primeira vez, o arranjo dos DBDs em relação aos LBDs. Primeiro, os domínios DBD de RXRa e PPARy estão ligados em lados opostos da dupla hélice de DNA, usando o eixo helicoidal como referência. Apesar desta organização dos DBDs, os LBDs formam uma interface de dimerização clássica usando suas hélices H10. Para permitir este arranjo, o domínio hinge do RXRa forma uma estrutura longa, flexível e desordenada com várias interações com o elemento responsivo. Essa estrutura também mostrou interações de interdomínio envolvendo RXRa DBD e PPARY LBD. Essa interação ocorre através da região das fitas- $\beta$ do LDB, o que pode explicar seu papel na ativação do receptor. ${ }^{35-36}$

\subsection{PPAR a PPAR $\beta / \delta$}

Nos seres humanos, o PPARa é expresso predominantemente no fígado, tecido adiposo e coração, esse receptor foi o primeiro a ser clonado a partir do cDNA de fígado de rato, controla a expressão de genes envolvidos na oxidação de ácidos 
graxos, transporte de lipídios, inflamação e gliconeogênese. ${ }^{37-39}$ PPARa é o alvo molecular para os fibratos, uma classe de medicamentos utilizados no tratamento da dislipidemia.

A ativação do PPARa por fibratos pode diminuir os níveis de triglicerídeos e aumentar as lipoproteínas de alta densidade (HDL), presumivelmente através do metabolismo de ácidos graxos e lipoproteínas. ${ }^{40}$ Os ligantes endógenos também são capazes de ativar esse receptor. Alguns ligantes endógenos incluem ácidos graxos insaturados e eicosanoides. Acredita-se que a ativação por ligantes endógenos ocorre principalmente durante os períodos de jejum, quando há uma grande quantidade de ácidos graxos livres no plasma sanguíneo. A ingestão dietética de ácidos graxos específicos também pode ser uma alternativa para a ativação de PPARa. ${ }^{41}$ Em suma, o PPARa é um importante sensor lipídico e regulador do metabolismo da energia celular e também pode melhorar a resistência à insulina em modelos genéticos e de alta qualidade de diabetes através de alterações na expressão gênica que evitam o ganho de peso e a adiposidade. ${ }^{37,42}$

O PPAR $\beta$, também conhecido como PPARס, foi originalmente clonado por Wahli e colegas em Xenopus laevis. ${ }^{43} \mathrm{~A}$ expressão ocorre em uma ampla gama de tecidos e células, mas em níveis elevados em tecidos relacionados à atividade metabólica, como tecido adiposo, fígado, pele, intestino, placenta, esqueleto, coração, e cérebro. ${ }^{44}$ É expresso de forma ambígua, e a falta de um ligante conhecido faz com que o PPAR $\beta$ seja menos estudado do que as outras isoformas do PPAR. No entanto, avanços importantes foram feitos em estudos genéticos e na síntese de agonistas seletivos para PPARß. É a isoforma mais abundante entre os três PPARs no músculo esquelético. Uma vez que o músculo esquelético representa cerca de $50 \%$ da massa corporal total, e mais de $50 \%$ do metabolismo ocorre nela. Portanto, as atividades envolvidas na contração muscular podem aumentar significativamente o gasto de energia e resultar no uso de glicose ou degradação de gordura como combustível. ${ }^{43-44}$

O PPARß, estimula o músculo esquelético para a quebra de gorduras armazenadas como combustível. Pode ser muito benéfico porque diminui os níveis de triglicerídeos e LDL-colesterol (colesterol ruim) e aumenta a sensibilidade à insulina e os níveis de colesterol HDL (colesterol bom). Uma vez que a síndrome metabólica é um problema causado pelo acúmulo de gordura armazenada no corpo, o PPARß foi reconhecido como uma possível solução. ${ }^{45}$ 
Esses avanços revelaram o papel desse receptor como um regulador do catabolismo de ácidos graxos e da homeostase de energia. ${ }^{46}$ Embora nenhum medicamento aprovado atuando unicamente ou principalmente no PPAR $\beta$ existe até o momento, os processos metabólicos regulados pelo PPAR $\beta$, como o metabolismo lipídico, a aterosclerose, o metabolismo da glicose e a sensibilidade à insulina, tornam este receptor potencial candidato para desenvolvimento de fármacos. ${ }^{47}$ Alguns processos inflamatórios também são atribuídos ao PPAR $\beta$, embora os mecanismos moleculares envolvidos não sejam completamente compreendidos. ${ }^{48-49}$

\subsection{PPARY}

O PPARy é expresso em uma ampla variedade de tecidos, incluindo coração, cólon, intestino delgado e grosso, rins, pâncreas e baço, sendo um promissor alvo terapêutico no tratamento de arteriosclerose e diabetes mellitus tipo II. ${ }^{22}$

Embora o PPARy seja transcrito por um único gene, apresenta quatro isoformas que se diferem na região 5' por splicing alternativo: $\mathrm{y} 1$ resulta em proteínas idênticas, é expressa praticamente em todos os tecidos, incluindo coração, rim, músculo, cólon e pâncreas; y2 contém uma região N-terminal composta por 28 aminoácidos, é expressa principalmente no tecido adiposo, $\mathrm{\gamma} 3$ parece ser a isoforma predominante nos macrófagos e 44 não é muito conhecida, porém foi demonstrada a presença de seu mRNA no tecido adiposo. ${ }^{2,5}$

A maior expressão do PPARy ocorre no tecido adiposo, onde ele é considerado a chave para a cascata de transcrição, que leva à diferenciação de adipócitos. A ativação do PPARy favorece a formação de pequenos adipócitos que tendem a substituir os grandes adipócitos que normalmente constituem o tecido adiposo branco. ${ }^{50-51}$ Foi demonstrado que a maior expressão do PPARy ocorre após as refeições e a sua ativação leva à expressão de genes que promovem a captação, armazenamento e metabolismo de ácidos graxos como a lipoproteína lípase, acetil coenzima A (acetil-CoA), proteínas transportadoras de ácidos graxos e fosfoenol piruvato carboquinase. Ele também reprime genes que induzem a lipólise e a liberação de ácidos graxos livres em adipócitos. Além disso, o PPARy diminui a expressão de leptina, uma molécula sinalizadora produzida pelo adipócito, o que causa um aumento na ingestão e otimização do uso de energia, contribuindo para os efeitos adipogênicos do PPARy. ${ }^{11,52-53}$ 
O PPARy possui um papel central na integração do controle energético, do metabolismo de glicose e lipídeos, também está envolvido na inibição da produção de citocinas inflamatórias (interleucina-6 (IL-6) e o fator de necrose tumoral a (TNF$\alpha$ ), pelos monócitos e também atua na repressão de genes pró-inflamatórios. ${ }^{10,22} \mathrm{~A}$ inibição dessas citocinas inflamatórias como a IL-6 e TNF- $\alpha$, acontece devido a ativação do PPARy. ${ }^{54}$ Por este motivo, o TNF- $\alpha$ é um dos responsáveis pela resistência à insulina, já que as citocinas estão relacionadas ao processo de inflamação, a sensibilização à insulina e obesidade. No entanto, a compreensão deste mecanismo ainda é obscura. ${ }^{2}$

$A$ atividade transcricional de PPARy também é regulada pelo seu estado de fosforilação. A fosforilação de PPARy na posição da Serina 273 (Ser) pela quinase 5 dependente da ciclina (Cdk5), e foi recentemente ligada à obesidade e aos ligantes anti-diabéticos do PPARy (por exemplo, a tiazolidinediona e rosiglitazona), que demonstraram inibir a fosforilação mediada por Cdk5 de PPARY no tecido adiposo. ${ }^{34,55-56}$ Além disso, vários ligantes do PPARy com pouca atividade agonística mas potentes efeitos anti-diabéticos in vivo revelaram ser fortes inibidores da fosforilação de PPARy por Cdk5. Consequentemente, a inibição direcionada da fosforilação de PPARy na Ser273 foi sugerida como uma abordagem promissora para o desenvolvimento de uma nova geração de agentes antidiabéticos. ${ }^{29,55}$

\subsection{Ligantes naturais e sintéticos do PPARY}

Devido ao papel fundamental que o PPAR desempenha no metabolismo dos lipídios, a procura de ligantes naturais começou com ácidos graxos e de eicosanoides. $\mathrm{Na}$ verdade, tais metabólitos foram identificados como ligantes naturais genuínos dos PPARs. Os ensaios de transativação baseados em células e, mais recentemente, estudos de ligação direta foram utilizados para caracterizar estes efeitos endógenos do receptor. ${ }^{57}$

Ácidos graxos e derivados eicosanoides ligam-se e ativam o PPAR em concentrações de micromolares. O PPARY prefere claramente ácidos graxos poliinsaturados, incluindo os ácidos graxos essenciais, ácido linoleico, ácido linolênico, ácido araquidônico e ácido eicosapentaenoico. ${ }^{57-61} \mathrm{~A}$ afinidade em micromolar destes metabolitos está de acordo com seus níveis séricos. No entanto, as suas gamas de concentrações intracelulares são desconhecidas. Do ponto de vista 
patológico, esses receptores estão relacionados a doenças metabólicas (principalmente, diabetes mellitus tipo 2, síndrome metabólica e dislipidemia), ${ }^{62-65}$ processo inflamatório, ${ }^{66-67}$ neurodegeneração ${ }^{68}$ e alguns tipos de câncer. ${ }^{69-71}$

O tratamento de diabetes mellitus tipo 2 (DM2) e síndrome metabólica (MS) traz um foco importante para o desenvolvimento de novos agonistas de PPAR. Existem pelo menos duas classes de agentes farmacológicos direcionados aos PPARs. Os fibratos que são conhecidos como ligantes do PPARa utilizados para o controle da hipercolesterolemia, enquanto as tiazolidinedionas (TZDs), como a troglitazona, a rosiglitazona e a pioglitazona, que são agonistas totais do PPARY, são utilizados como sensibilizadores de insulina na terapia da DM2 e possuem alta afinidade e seletividade ao PPARy (Figura 9) e foram identificadas como ligantes sintéticos do PPARy. ${ }^{72-73}$

A troglitazona foi retirada do mercado em 2000 , devido à hepatotoxicidade. ${ }^{74}$ Apesar da eficácia clara para restaurar os níveis de glicose no sangue, a rosiglitazona causou efeitos colaterais importantes, como retenção de líquidos, aumento de peso e aumento da chance de um evento cardiovascular. Esses efeitos levaram algumas agências reguladoras ao redor do mundo a restringir ou suspender o uso de rosiglitazona. Curiosamente, a pioglitazona mostrou ser um fármaco mais seguro que a rosiglitazona, levantando duas considerações interessantes sobre as interações entre PPARY e seus agonistas, e ainda é usado como um agente hipoglicemiante oral. ${ }^{33}$ Conforme observado por Bruning e colaboradores, ${ }^{75}$ pequenas mudanças no modo de ligação, observadas entre rosiglitazona e pioglitazona, podem levar a mudanças importantes no perfil farmacológico, incluindo os efeitos colaterais. ${ }^{74-75}$

Outras classes de fármacos que também são utilizadas no tratamento de diabetes tipo 2 são: biguanidas que agem através da diminuição da quantidade de glicose liberada pelo fígado; sulfonilureias que estimula o pâncreas para liberar mais insulina; meglitinidas que age através da estimulação do pâncreas para liberar mais insulina logo após uma refeição; inibidores da alfa alfaglicosidase no qual ocorre um retardo da absorção de carboidratos; gliptinas em que ocorre um aumento da síntese e secreção da insulina e inibidores da SGL T2 que inibe a reabsorção de glicose nos rins, aumentando assim, a liberação do excesso de glicose na urina. ${ }^{70-75}$

As vantagens de se utilizar os hipoglicemiantes orais é que eles melhoram a liberação ou a ação da insulina. E os TZDs apresentam bons resultados na 
manutenção de controle glicêmico em longo prazo em comparação com outros hipoglicemiantes orais como a metformina e as sulfonilureias. Tais resultados justificam os TZDs como uma das opções terapêuticas mais utilizadas no tratamento de diabetes tipo $2 .^{75}$

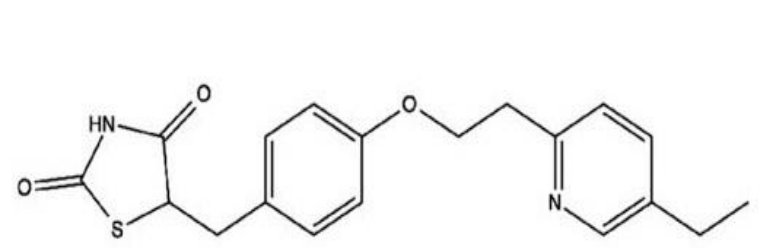

Pioglitazona

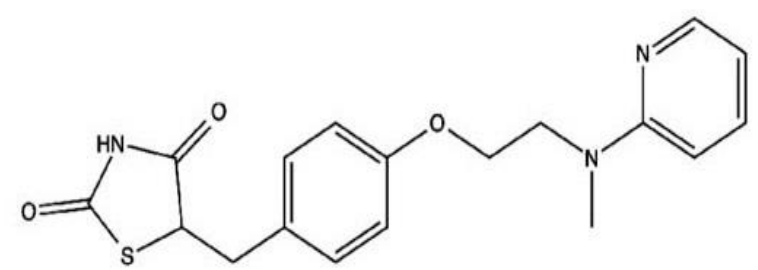

Rosiglitazona

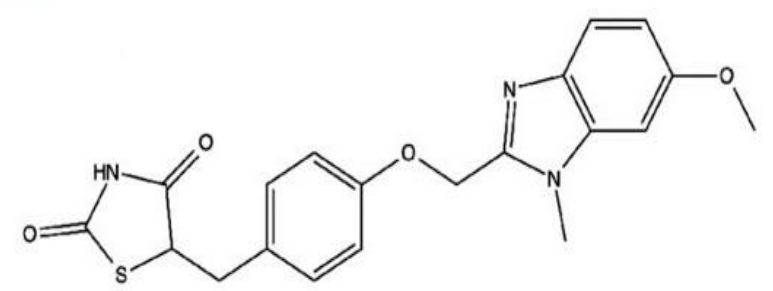

Rivoglitazona

Figura 9 - Estrutura química das tiazolidinadionas (TZDs).

Fonte: Elaborada pela autora.

A habilidade única dos ligantes do PPARy para melhorar a resistência à insulina é claramente relacionada por efeitos colaterais que limitam seu uso clínico. No caso de outro receptor nuclear, o receptor de estrogênio (ER), considerações semelhantes, levou ao desenvolvimento dos moduladores seletivos do receptor estrógeno (SERM), que têm melhorado o índice terapêutico no cancro da mama e osteoporose porque eles regulam a atividade de ER.

As propriedades do PPARy nos adipócitos sugere que pode ser um possível modulador de forma seletiva a atividade do PPARY de maneira análoga. Por exemplo, o PPARy é necessário para a expressão da proteína de ligação de ácido graxo específico de adipócitos aP2. ${ }^{76}$ Em adipócitos maduros, mesmo na ausência de um ligante sintético, o PPARy se liga ao promotor aP2 (proteína adipócita 2), juntamente com proteínas coativadoras. ${ }^{77}$ Isso ainda não é claro se é devido à atividade constitutiva de PPARy ou à presença de um ligante endógeno. No entanto, nas mesmas células, outros genes alvo de PPARy, como glicerol quinase e OLR-1 (Receptor da lipoproteína de baixa densidade oxidado 1), requerem um ligante exógeno para ativação. ${ }^{76-77} \mathrm{Na}$ ausência do TZD ou outro potente ligante sintético, o 
PPARy recruta correpressores para esses genes, que pode estar relacionado com a sensibilidade à insulina. ${ }^{77}$

\subsection{Agonistas totais e agonistas parciais do PPARy}

Os ligantes podem ser classificados como agonistas totais ou agonistas parciais dependendo do grau de ativação do receptor observado in vitro, sendo que são considerados agonistas totais os ligantes que provocam a ativação máxima do receptor. ${ }^{78}$ Os melhores exemplos de agonistas totais do PPARY são os TZDs. ${ }^{10}$ Já os ligantes que não causam ativação máxima do receptor, mesmo em altas concentrações, são chamados agonistas parciais.

Os agonistas parciais são definidos como ativadores fracos de PPARY que provocam o mesmo padrão de ativação e mostram curvas dose-resposta vinculadas com menor potencial de transativação em comparação com agonistas totais. Eles podem induzir conformações de receptores alternativos, e, assim, recrutar diferentes co-ativadores, resultando em efeitos de transcrição distintos. ${ }^{77-}$ ${ }^{79}$ Em particular, eles formam interações eletrostáticas com a arginina $(R)$ 288, bem como interações extensas de van der Waals com a interleucina (I) 341 da folha $\beta$ e $\mathrm{C} 285$ da $\mathrm{H} 3^{75,80}$

Nos últimos anos, um novo mecanismo antidiabético foi proposto dependendo da inibição da fosforilação da Ser 273 do PPARy pela Cdk5. ${ }^{55}$ Esta inibição mantém a transcrição de vários genes sensíveis à insulina, como adiponectina e adipina. ${ }^{55}$ Curiosamente, a obesidade e outros sinais próinflamatórios induzem a fosforilação da Ser 273 do PPARY, explicando por que as pessoas obesas também desenvolvem resistência à insulina. Dado que o sítio de reconhecimento Cdk5 se estende para a primeira vertente $\beta$ de PPARY, estabilização estrutural da região da folha $\beta$, provocada por agonistas parciais, presumivelmente torna o resíduo da Ser 273 menos acessível à quinase, protegendo o receptor da fosforilação, ${ }^{55}$ Um evento que se correlaciona bem com os efeitos de redução da glicose. Isso pode explicar como os agonistas parciais PPARy podem exibir efeitos antidiabéticos semelhantes ou superiores aos dos TZDs e outros agonistas totais. ${ }^{79}$

Três agonistas parciais têm sido descritos mais recentemente, e os seus perfis in vitro/in vivo comparados com os agonistas totais, que são o MRL24, o GQ- 
16 e o INT131 (Figura 10). O MRL-24 se liga ao PPARy com uma afinidade de $3 \mathrm{nM}$, entretanto a ativação do receptor é somente de $20 \%$ comparado a ativação pela rosiglitazona um agonista total do PPARy, ${ }^{81}$ que é suficiente para regular os níveis de glicose num modelo de ratos diabéticos, e reduzindo o ganho de peso quando comparado com rosiglitazona. Acton e colaboradores ${ }^{81}$ mostraram que a rosiglitazona (10 mg/ kg/dia) resultou num aumento de peso de $10 \%$ em um modelo de rato, enquanto MRL24 usado com a mesma dose causou apenas um ganho de peso de $3 \%$. $^{10,81}$

GQ-16 é outro ligante TZD, e seu efeito de ativação é de somente 30\% quando comparado à rosiglitazona, sendo que um de seus anéis não interage com a hélice H12. Ele é menos eficaz em causar a diferenciação de adipócitos que rosiglitazona, resultando num menor ganho de peso. ${ }^{82}$ Ambos GQ-16 e MRL24 podem interagir com a Ser 273 no LBD. A fosforilação deste resíduo de serina é associada com um efeito adipogênico. ${ }^{10,82}$ Os ligantes GQ-16 e MLR-24 usam uma região diferente do bolsão de ligação do PPARY para interação molecular, uma região localizada entre a hélice $\mathrm{H} 3$ e a folha $\beta$, o que está longe da hélice $H 12$, sem qualquer interação com esta. A posição ocupada por estes ligantes tem sido explicada como a razão para as suas propriedades funcionais distintas. Em ambos os casos, a espectrometria de massa e experiências de troca de hidrogênio-deutério mostrou que os ligantes que estabilizam as folhas- $\beta$, em um perfil de interação diferente do que é observada para o ligante TZD.

Este local de ligação utilizado pelo MRL24 e GQ-16 também está perto da Ser 273, bloqueando a fosforilação deste resíduo por Cdk5. Geralmente quando ocorre essa ativação da fosforilação, desencadeia uma expressão gênica levando a obesidade na maioria dos casos. ${ }^{55,83}$

Estruturalmente, os agonistas totais interagem diretamente com a $\mathrm{H} 12$ e estabilizam a conformação agonista através de uma ligação direta com a hidroxila da Tirosina (Tyr) 473, permitindo que a H12 se encaixe com a H3 e H10/H11. Já a interação dos agonistas parciais durante a ativação do PPARY acontece sem uma interação direta com o H12. ${ }^{75}$ Devido ao grande volume do LBD, estes agonistas parciais podem ocupar uma região diferente do local de ligação. Interações indiretas com a $\mathrm{H} 12$ podem ser consideradas características de agonistas parciais. Um exemplo deste tipo de interação é visto para o INT131 agonista parcial, um ligante não TZD em fase III de ensaios clínicos. INT131 é um ligante muito seletivo que 
pode ativar parcialmente o PPARy e tem pouco efeito sobre o acúmulo de lipídios nos adipócitos 3T3-L1. Semelhante a outros ligantes do PPARY, INT131 não faz uma interação com a $\mathrm{H} 12$ e necessita de uma molécula de água para mediar o contato com a Try473. ${ }^{75,82-83}$

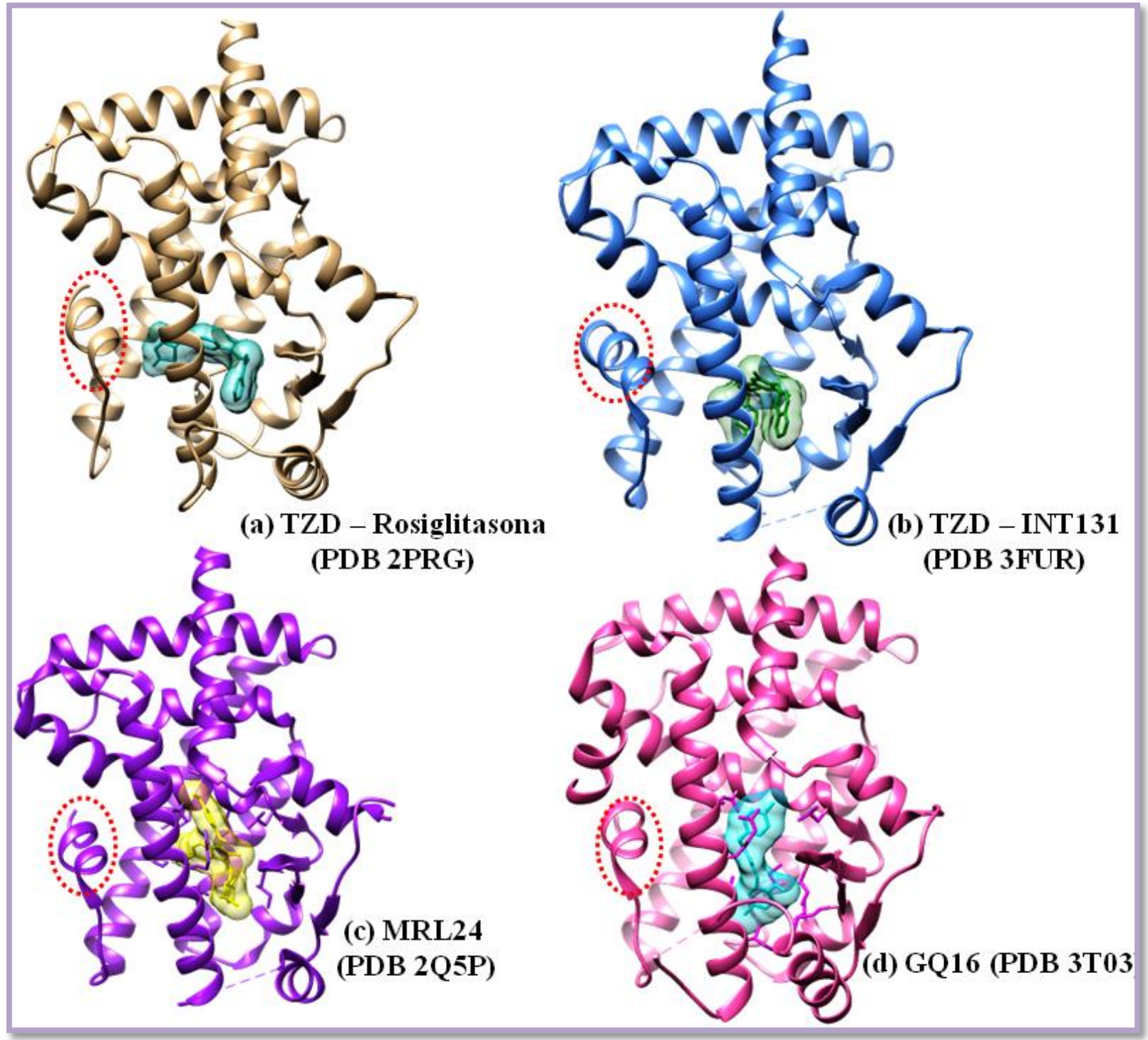

Figura 10 - Estrutura tridimensional do PPARy mostrando na região do bolsão de ligação agonistas totais e parciais. Em A está representado o agonista total do PPARY a TZD roziglitasona, nela pode-se notar que o ligante está próximo a $\mathrm{H} 12$, diferente do que está representado em b, c e d onde os agonistas parciais INT131, MRL24 e GQ16 não estão interagindo diretamente com a $\mathrm{H} 12$ através de interações hidrofóbicas. Em todas as estruturas a H12 está mostrada com linhas tracejadas em vermelho.

Fonte: Elaborada pela autora. 


\subsection{PPARY em doenças associadas ao risco cardiovascular}

\subsubsection{Diabetes}

O tratamento atual da diabetes com medicamentos que reduzem a glicose permite controlar as complicações microvasculares, como retinopatia e melhorar a qualidade de vida do paciente. No entanto, tem pouco efeito sobre a patologia macrovascular que explica o aumento do risco de eventos cardiovasculares fatais. Além disso, o controle glicêmico agressivo parece proporcionar pouco benefício nos estágios avançados da doença, e pode até ser prejudicial. ${ }^{85,86}$ Numerosos estudos clínicos objetivaram melhorar a terapia antidiabética com novos medicamentos que têm potenciais benefícios para os pacientes. Os agonistas de PPARy normalizam o perfil de glicose aumentando indiretamente a absorção de glicose estimulada pela insulina por tecidos periféricos e diminuindo a gliconeogênese hepática. ${ }^{87-88}$ Eles também têm efeitos moderados na redução do colesterol LDL, embora os mecanismos desse efeito ainda são pouco estudados.

A atividade anti-inflamatória dos agonistas do PPARy também pode contribuir para o seu efeito anti-aterosclerótico. Estudos em modelos de ratos demonstraram que a ativação de PPARy reduziu a inflamação e melhorou a sensibilidade à insulina através da ativação de células reguladoras na gordura visceral. ${ }^{89}$ Outro estudo demonstrou que os efeitos anti-diabéticos da ativação de PPARY também são mediados pela inibição da expressão de progranulina induzida por TN- $\alpha$, que tem um efeito pró-inflamatório no tecido adiposo. Como já foi abordado na seção 1.6 três TZDs foram aprovados para o tratamento de diabetes tipo 2: rosiglitazona, pioglitazona e troglitazona, sendo que esta última foi retirada logo após a aprovação devido a problemas de hepatoxicidade. ${ }^{88-89}$ Os efeitos da pioglitazona nos resultados macrovasculares em diabetes foram realizados em pacientes com diabetes tipo 2 e doença cardiovascular. ${ }^{90-91} \mathrm{~A}$ pioglitazona foi utilizada como adição à terapia antidiabética estabelecida que incluiu medicamentos para reduzir a glicose e lipídios, anti-hipertensivos e antitrombóticos, e reduziu a mortalidade por todas as causas, infarto do miocárdio não fatal e acidente vascular cerebral em pacientes com alto risco cardiovascular em comparação com o placebo. Outros resultados macrovasculares, como a intervenção endovascular ou cirúrgica nas artérias 
coronárias ou nas pernas, também foram reduzidas, embora a significância estatística para elas não tenha sido alcançada. ${ }^{55,91}$

O outro agonista do PPARy, a rosiglitazona, foi, pelo contrário, associado a uma taxa significativamente aumentada de infarto do miocárdio e eventos cardiovasculares fatais. ${ }^{92,93}$ Outros estudos comparativos confirmaram os elevados riscos associados à droga. Para explicar esta discrepância, diferentes autores apontaram os efeitos benéficos da pioglitazona no perfil de lipoproteínas que não são compartilhados pela rosiglitazona. De fato, a pioglitazona não só aumentou o HDL, mas também diminuiu os triglicerídeos em jejum, enquanto que a rosiglitazona teve apenas efeitos sobre HDL. ${ }^{94}$ Além disso, a rosiglitazona aumentou os níveis de colesterol total e LDL que não foram afetados pela pioglitazona. ${ }^{93,95} \mathrm{Em}$ conjunto, os resultados de vários ensaios clínicos demonstram que a pioglitazona possui uma forte vantagem em relação à rosiglitazona na normalização do perfil de lipoproteínas plasmáticas e colesterol. Por causa das questões de segurança, a aprovação da rosiglitazona foi retirada pela Agência Europeia de Medicamentos. ${ }^{96}$

\subsubsection{Aterosclerose}

Evidências demonstram que os agonistas do PPARy têm potencial para o tratamento da aterosclerose para melhorar a função endotelial, diminuir a progressão das placas ateroscleróticas e reduzir a inflamação crônica e a trombose, resultando na redução do risco de eventos cardiovasculares. ${ }^{97} \mathrm{O}$ desenvolvimento e o progresso da aterosclerose estão estreitamente associados à inflamação. Uma das alterações patológicas do sistema imune observado na aterosclerose é a polarização de macrófagos alterados para fenótipos pró ou anti-inflamatórios (M1 ou M2) ${ }^{98}$ PPARY parece ser um potente regulador desse processo. ${ }^{99}$ Seus agonistas mostraram suprimir o fenótipo M1, inibindo a expressão do fator de necrose tumoral$\alpha$, interleucina (IL) $-1 \beta$, citocinas pró-inflamatórias, E IL-6. ${ }^{100}$ Por outro lado, a diferenciação M2 de macrófagos resultou no aumento da expressão de PPARY. Essa regulação da polarização de macrófagos é um dos mecanismos subjacentes à atividade anti-inflamatória e anti-aterosclerótica do PPARy. ${ }^{101}$ 


\subsubsection{Hipertensão}

Os PPARs têm sido ativamente estudados como potentes reguladores da hipertensão. $O$ efeito de redução da pressão arterial de agonistas de PPARY foi relatado em vários estudos clínicos, incluindo um grande estudo realizado em pacientes com diabetes tipo $11 .{ }^{90}$ Estudos em animais demonstraram que as TZDs diminuíram a expressão de um dos componentes do sistema renina-angiotensinaaldosterona, receptor da angiotensina II tipo 1 (AT1R), nas células musculares lisas vasculares de uma maneira dose-dependente. ${ }^{102}$ Além disso, estudos in vitro demonstraram que os agonistas de PPARy tiveram um efeito inibitório sobre a indicação de aldosterona sintase induzida pela angiotensina II e a secreção de aldosterona. ${ }^{101}$ Outros autores demonstraram que os agonistas do PPARy suprimem a fosfatidilinositol 3-quinase induzida por angiotensina II e MAP quinase in vivo. ${ }^{102}$ Juntas, essas observações indicam que a ativação de PPARy desempenha um papel importante no controle da hipertensão arterial, interferindo nas vias mediadas pela angiotensina II. ${ }^{103-104}$

Estudos em modelos animais demonstraram que as mutações negativas dominantes de PPARy foram associadas à hipertensão sem afetar os componentes do sistema renina-angiotensina-aldosterona. ${ }^{103}$ Portanto, é provável que o PPARY exerça sua atividade hipotensora através de vários mecanismos diferentes.

\subsubsection{Angiogênese}

A angiogênese desempenha um papel importante nas doenças cardiovasculares, incluindo a doença isquêmica do coração e a isquemia dos membros, proporcionando um meio para salvar os tecidos hipoperfundidos. $O$ processo também é importante no câncer, onde contribui para o crescimento do tumor. $O$ regulamento da angiogênese é realizado por uma série de fatores de crescimento e citocinas, que são produzidos em resposta a sinais hipóxicos e inflamatórios. O fator de crescimento endotelial vascular (VEGF) é um desses fatores, que estimula a proliferação e diferenciação endotelial. ${ }^{104}$ Os PPARs estão envolvidos na angiogênese em várias condições, embora seu papel permaneça contraditório, uma vez que tanto os efeitos pró e anti-angiogênicos foram 
observados. ${ }^{105}$ Também foi demonstrado que o efeito de agonistas de PPARy em células endoteliais dependia da dose, com efeito angiogênico presente apenas em baixas concentrações. ${ }^{106} \mathrm{O}$ PPARY demonstrou regular positivamente a angiogênese aumentando a expressão do receptor-2 do VEGF. Os autores relatam que a atividade anti-angiogênica da aldosterona foi mediada pela inibição da expressão de PPARy e subsequentemente pelo receptor VEGF-2 em células endoteliais vasculares. ${ }^{107}$ Outro estudo demonstrou que a supressão da sinalização PPARy nas células endoteliais da artéria pulmonar pela angiogênese reduzida de endotelina-1 na hipertensão pulmonar persistente. ${ }^{108} \mathrm{Em}$ células estelares hepáticas, no entanto, A ativação de PPARY inibiu a transdução de sinal angiogênico através da transrepressão do receptor beta de fator de crescimento derivado de plaquetas (PDGF), levando a uma expressão reduzida de VEGF. ${ }^{109}$ Portanto, é provável que as propriedades pró e anti-angiogênicas de PPARY dependam dos antecedentes locais e dos processos de sinalização. No entanto, o estudo posterior do PPARY pode ser interessante para a compreensão e possível regulação da angiogênese em várias condições patológicas.

\subsubsection{Disfunção renal}

A ativação de PPARY demonstrou ter efeitos protetores na disfunção renal, incluindo nefropatia diabética e condições não-diabéticas, tanto em modelos animais como em estudos clínicos. ${ }^{110-111}$ Os TZDs pareciam ser agentes potentes para reduzir a proteinúria em pacientes diabéticos. Eles também tiveram efeitos benéficos em pacientes com insuficiência renal crônica e hemodiálise. ${ }^{112-113}$ Numerosos modelos animais demonstraram o potencial de agonistas de PPARY para proteção renal em diversas condições, incluindo lesão renal induzida, doença renal policística e síndrome nefrítica. ${ }^{114}$ A redução da pressão arterial e a melhoria da função endotelial contribuem para a atividade renal dos agonistas do PPARy. No entanto, os mecanismos exatos desta atividade continuam a ser esclarecidos. ${ }^{112-114}$

\subsection{Novos Potenciais Farmacológicos}

Atualmente há um aumento notável na prevalência de pessoas que sofrem de distúrbios metabólicos como obesidade, diabetes tipo 2, doenças inflamatórias, 
câncer, aterosclerose e hipertensão dentre outras doenças cardiovasculares. Os PPARs têm sido considerados alvos terapêuticos no tratamento dessas doenças por ser um receptor nuclear de extrema importância farmacológica, envolvidos em vários processos metabólicos no organismo. ${ }^{16}$

Embora certo número de fármacos esteja disponível para um grande número dessas doenças metabólicas, como por exemplo, para o tratamento de diabetes tipo II com ação direta no PPARy. Os efeitos colaterais relacionados aos agonistas totais desse receptor como fármacos da classe das TZDs, que são fármacos caracterizados por diminuir a resistência à insulina, como a Rosiglitazona (comercializado como Avandia $\AA$ ) e Pioglitazona (comercializado como Actos $®$ ), os quais agem através da estimulação da máxima resposta transcricional do PPARy, porém apresentam diversos efeitos colaterais. ${ }^{16}$ Com isso a crescente epidemia dessas doenças metabólicas fortalece a relevância clínica desses receptores e indica que a descoberta de novos agonistas do PPARy é de grande valia para a indústria farmacêutica, já que essas novas estruturas poderão ser úteis no desenvolvimento de novos fármacos, principalmente na busca do melhoramento dos ligantes já existentes para este receptor ou na descoberta de novos ligantes mais promissores. 


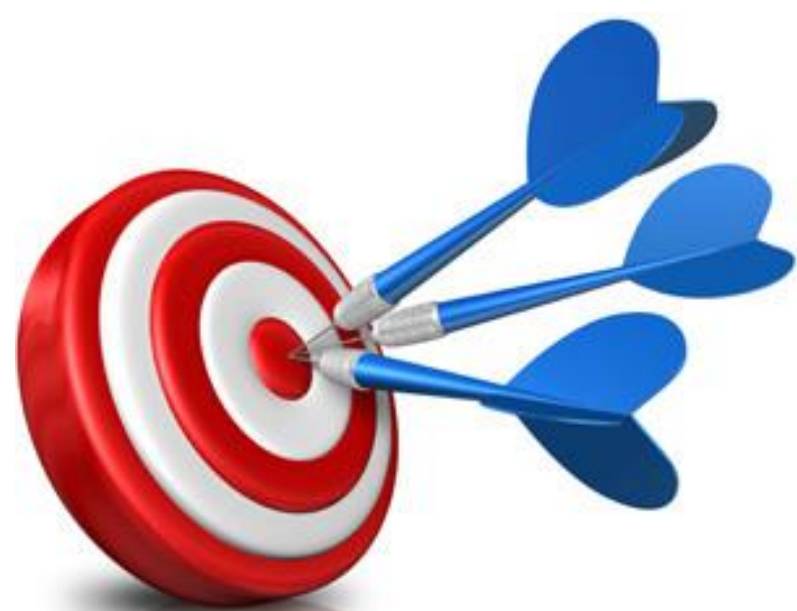

Capítulo 2

Objetivos e Justificativas 


\section{OBJETIVOS E JUSTIFICATIVA}

Devido à importância do PPARy no metabolismo de glicose e na sensibilização da insulina, o presente trabalho justifica-se como um esforço para avançar na compreensão da interação entre ligantes sintéticos com o receptor PPARY (bases estruturais) e a proposição de moléculas mais seguras e mais eficazes para a manutenção de níveis euglicêmicos. Em outros trabalhos realizados por pesquisadores do nosso grupo na busca por novos agonistas do PPARy a partir de uma abordagem baseada na estrutura. De forma simplificada estes ligantes foram identificados por docking molecular. Desses ligantes selecionados 5 foram abordados neste trabalho. Foram analisados ligantes que contém moléculas com um grupo carboxilato, geralmente em um sistema de três anéis com uma ligação rotacionável entre os anéis. Estes sistemas de três anéis são grandes o suficiente para encher a cavidade do receptor e a rotação da ligação é necessária para um ajuste perfeito no bolsão em forma de Y. Outros ligantes também contêm moléculas com grupos carboxilato, mas também possuem um grupo tetrazol. Ligantes que tenham este grupo tetrazol são de grande importância para a busca de novos agonistas do PPARy com efeitos colaterais reduzidos pois em uma patente publicada em 1989, foram feitos testes em ratos onde agentes hipoglicemiantes que apresentavam este grupo tetrazol tiveram como resultado a redução dos níveis de glicose no sangue desses ratos que sofriam de hiperglicemia e também diabetes.

Com base na importância do entendimento do mecanismo de interação entre os receptores PPAR e seus ligantes, o principal objetivo deste trabalho é ampliar as informações estruturais dos ligantes bioativos dos PPARs, a fim de propiciar subsídios para a análise dessas interações.

Os objetivos específicos incluem:

$>$ Expressão da proteína do LBD do PPARy humano em E. coli em larga escala com a técnica de DNA recombinante e purificação dessa proteína por cromatografia de afinidade e por exclusão molecular.

A cristalização do PPARy-LBD em complexo com ligantes sintéticos identificados em etapas de docking baseados na estrutura tridimensional da proteína. 
$>$ Determinação de estruturas cristalográficas por difração de raios-X e comparação com as estruturas já determinadas para a compreensão das bases moleculares da interação receptor-ligante. 


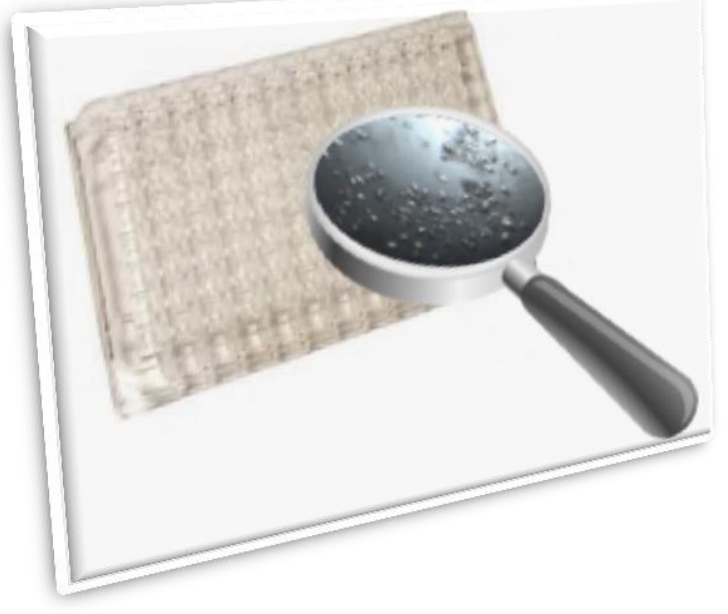

Capítulo 3 Metodologia 


\section{METODOLOGIA}

\subsection{Expressão do domínio PPARY-LBD}

O domínio LBD do PPARy humano foi clonado em vetor pET 28a(+) (Novagen) (aminoácidos L204 a Y477) e expressos em células de Escherichia coli BL21 (DE3). O vetor foi gentilmente cedido pelo Doutor André Ambrósio que fez a sub-clonagem no Instituto de Física de São Carlos - USP no seu doutoramento. Essas células foram crescidas em pré-inóculos $(5 \mathrm{~mL})$ por $16 \mathrm{~h}$ a $37^{\circ} \mathrm{C}$ em meio Luria-Bertani (LB) ( $10 \mathrm{~g}$ de triptona, $5,0 \mathrm{~g}$ de levedura, $10 \mathrm{~g}$ de $\mathrm{NaCl}, \mathrm{pH} 7,5$ para cada litro de cultura) com $50 \mu \mathrm{g} / \mathrm{mL}$ de canamicina. Logo após, estes pré-inóculos foram colocados em $1 \mathrm{~L}$ do meio LB onde cresceram a $37^{\circ} \mathrm{C}$ sob agitação de $120 \mathrm{rpm}$ até atingir uma D.O $\mathrm{O}_{600}$ entre 0,7 - 1,0 (densidade ótica medida à $600 \mathrm{~nm}$ ), em seguida, a expressão proteica na cultura foi induzida com $1 \mathrm{mM}$ de isopropil- $\beta-D-1$ tiogalactopiranosideo (IPTG) por $16 \mathrm{~h}$ à $19^{\circ} \mathrm{C}$.

Após esse período, o meio foi centrifugado a $4200 \mathrm{~g}$ em rotor SLC-6000 por 20 minutos a $4^{\circ} \mathrm{C}$, e o sobrenadante descartado e o sedimento foi ressuspendido no tampão 1 (50mM Tris- $\mathrm{HCl}$ pH 8,0,100mM NaCl, 10\% de glicerol, 5mM de imidazol e $1 \mathrm{mM}$ de Ditiotreitol (DTT)). A lise das bactérias foi feita com a adição de $0,1 \mathrm{mg} / \mathrm{mL}$ de lisozima e $1 \mathrm{mM}$ de fluoreto de fluoreto fenilmetilsulfônico (PMSF) e mantendo em banho de gelo por uma hora, para a prevenção de ocorrência de lise enzimática e da ação de proteases, respectivamente. Posteriormente, as células foram rompidas por sonicação com pulsos de 30 segundos por 5 ciclos com intervalos de 30 segundos em banho de gelo, para garantir que a parede celular fosse rompida completamente. A fração solúvel foi separada por centrifugação a $17000 \mathrm{~g}$ em rotor SS34 por 20 minutos a $4^{\circ} \mathrm{C}$.

\subsection{Purificação do PPARY-LBD por cromatografia de afinidade}

O protocolo de purificação utilizado para a proteína expressa emprega como primeiro passo uma coluna de afinidade, já que a mesma possui uma cauda com 6 histidinas na sua porção N-terminal, uma vez que esses aminoácidos possuem uma alta afinidade para ligação em resinas de cromatografia que contém íons metálicos 
$\left(\mathrm{Ni}^{2+}\right.$ e $\left.\mathrm{Co}^{2+}\right)$, esta técnica é conhecida como IMAC (Imobilized Metal ion Affinity Chromatografy). Os sobrenadantes, que contém a proteína de interesse, resultantes do processo de lise celular foi purificado utilizando $4 \mathrm{~mL}$ de resina de níquel $(\mathrm{Ni}$ Superflow, Clontech) pré-equilibrada com o tampão 1 (50mM Tris- $\mathrm{HCl}$ pH 8,0, $100 \mathrm{mM} \mathrm{NaCl}, 10 \%$ de glicerol, $5 \mathrm{mM}$ de imidazol). A eluição da proteína da resina de afinidade foi realizada com um gradiente de 5 a $300 \mathrm{mM}$ de imidazol. As amostras obtidas foram analisadas em técnca SDS-PAGE 15\% (dodecil sulfato de sódio, gel de policrilamida para eletroforese), as bandas foram visualizadas através das colorações Coomassie Blue $(0,25 \%$ de Coomassie briliant blue, $90 \%$ de etanol absoluto e $10 \%$ de ácido acético glacial).

\subsection{Purificação por cromatografia por exclusão de tamanho}

Para obtenção de um maior grau de pureza, as amostras obtidas após a purificação por cromatografia de afinidade foram submetidas a um segundo passo de purificação, por cromatografia por exclusão de tamanho. Para isto, foi utilizada uma coluna Hi-load 16/60 Superdex 75 PG de $120 \mathrm{~mL}$ acoplada a um cromatógrafo do tipo ÄKTA Purifier (GE Life Sciences, EUA). A coluna foi previamente lavada e equilibrada com tampão contendo $50 \mathrm{mM}$ de Tris- $\mathrm{HCl}$ pH 8,0, $100 \mathrm{mM}$ de $\mathrm{NaCl}, 1$ $\mathrm{mM}$ de DTT e $5 \%$ de glicerol. Em cada corrida, foram injetados $5 \mathrm{~mL}$ da amostra concentrada de proteína. As amostras foram eluídas da coluna de gel filtração com um fluxo de $1 \mathrm{~mL} / \mathrm{min}$. As amostras obtidas foram analisadas em SDS-PAGE 15\%.

\subsection{Seleção dos ligantes}

Cinco ligantes foram inicialmente selecionados para caracterização in vitro e estrutural. Todos estes ligantes foram identificados como ligantes do receptor PPARy em projetos anteriores desenvolvidos no grupo de Biotecnologia molecular do Instituto de Física de São Carlos, através de simulações de docking molecular e/ou através de inferências baseadas na similaridade tridimensional dos ligantes. Essa técnica tem sido utilizada na identificação de moduladores do receptor PPARy, sendo uma estratégia bastante utilizada na indústria farmacêutica na busca desses novos moduladores e é baseada na estrutura tridimensional do receptor. 
De forma simplificada os ligantes foram identificados utilizando o programa UCSF DOCK 3.5.54 por docking molecular. Foi utilizado um subset para a busca na base de dados ZINC, que contém mais de 21 milhões de compostos disponíveis comercialmente para a descoberta de novos fármacos, baseados em docking molecular. ${ }^{114}$ A estrutura cristalina utilizada para a docagem no LBP do PPARy foi PDB 1FM6. Foi utilizado o campo de força AMBER na atribuição das cargas para os átomos da proteína.

Quatro ligantes sintéticos são oriundos de campanhas baseadas na estrutura do receptor e um fármaco já aprovado é oriundo de campanha baseada na estrutura do ligante rosiglitazona. Na maioria das estruturas o grupo polar ácido carboxílico está presente possivelmente interagindo com os aminoácidos da região polar do sítio ativo, próxima à hélice $\mathrm{H} 12$. Adicionalmente, dois ligantes com anel tetrazol foram selecionados, uma vez que o grupo tetrazol é um grupo bioisóstero do grupo carboxilato e que as simulações de docking indicavam interações viáveis destes compostos com o receptor. As estruturas dos ligantes selecionados estão demonstradas na Figura 11. Os 5 compostos foram adquiridos de diferentes empresas e seus respectivos códigos na base de dados ZINC (1) são: ligante 1ZINC1529323, 2- ZINC18456289, 3- ZINC4999773, 4- ZINC4999766 e 5ZINC980559.

Estes compostos foram identificados através de uma busca previamente realizada por compostos similares à rosiglitazona em uma base de dados de compostos com uso aprovado pelo FDA (Food and Drug Administration). A similaridade foi avaliada através da comparação da distribuição do volume molecular e da distribuição de cargas no espaço usando o programa MolShaCS ${ }^{115}$ desenvolvido no grupo de Biotecnologia Molecular. 
<smiles>CC(C)C(=O)OCc1ccccc1</smiles><smiles>[4H]OC(=O)[C@H](CCOc1ccccc1)NC(=O)c1ccc(NCc2cnc3[nH]c(N)nc(=O)c3n2)cc1</smiles><smiles>[PH3+]c1ccc(COc2cccc(CNc3nn[n-]n3)c2)cc1</smiles>

$\mathrm{N}-[[$ 3-(p-tolylmethoxy)pheny 1$]$ methyl $]-2 \mathrm{H}-$<smiles>Cc1ccc(COc2ccccc2CNc2nn[n-]n2)cc1</smiles>

2H-1,2,3,4-tetraazol-5-yl(\{2-[(4methylphenyl)methoxy]phenyl $\}$ me thyl)amine

(4)

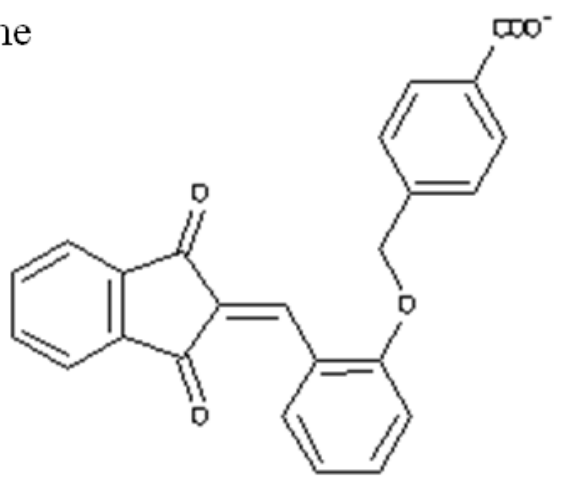

4-( \{2-[(1,3-dioxo-1,3-dihydro-2H-inden-2ylidene)methyl]phenoxy ; methyl)benzoic acid

Figura 11 - Estrutura química dos ligantes selecionados a partir do docking.

Fonte: Elaborada pela autora.

\subsection{Ensaios de cristalização do PPARY com os ligantes sintéticos}

A cristalização de macromoléculas é um processo pelo qual essas proteínas se juntam em arranjos periódicos e organizados, formando cristais. Uma das técnicas mais utilizadas para a cristalização de macromoléculas biológicas é a técnica de difusão de vapor, que tem como objetivo levar a solução contendo a 
proteína de interesse para um estado de supersaturação, para que ocorra a diminuição da solubilidade. Esta técnica pode ser ainda dividida na técnica de gota pendurada (hanging drop) ou da gota sentada (sitting drop). Na figura 12a mostra o processo de difusão de vapor (hanging drop), onde a gota contém a proteína purificada, solução tampão e agente precipitante. Com o tempo essa gota alcança um equilíbrio entre as duas soluções. Após a evaporação da água, a concentração do agente precipitante na gota aumenta e levará a condição de supersaturação propícia para a formação de cristais. ${ }^{116}$

Para a formação de um cristal de qualidade adequado para o experimento de difração de raios-X depende de vários parâmetros como: $\mathrm{pH}$, temperatura, solubilidade, agente precipitante, aditivos, agentes orgânicos, o que justifica a complexidade envolvida na obtenção de cristais de macromoléculas. A condição de cristalização pode ser predita pelo diagrama de fases (Figura 12b), e o objetivo principal da cristalização é a determinação da zona de metaestabilidade associada a nucleação e crescimento de cristais. ${ }^{117}$

$\mathrm{Na}$ cristalização a amostra inicialmente se encontra em uma solução aquosa saturada, estabilizada por um tampão contendo agente redutor, sal, ligante ou outro reagente como, por exemplo, detergentes, impossibilitando o crescimento de cristais. É necessário que ocorra a saturação para que haja a formação de cristais, provocando um desequilíbrio na amostra havendo uma perturbação no sistema. A solubilidade é diminuída com a adição de um agente precipitante e concomitantemente a saturação nas três diferentes zonas ou fases aumenta. A zona metaestável é uma fase em que os núcleos dos cristais não crescem, porém os cristais de seeding crescem nessa zona. A segunda fase é a zona de nucleação, onde os cristais e os núcleos podem ocorrer espontaneamente, porém se formam muitos microcristais semelhantes a um pó cristalino. Na zona de precipitação ocorre a precipitação da amostra, ou seja, quando o excesso da macromolécula se separa da solução sob a forma de um precipitado amorfo. ${ }^{118}$

Apesar desta técnica de cristalização apresentar uma grande evolução, principalmente devido à inserção da robotização, a cristalização de proteínas de interesse ainda tem sido um desafio para projetos que envolvam esta técnica. 


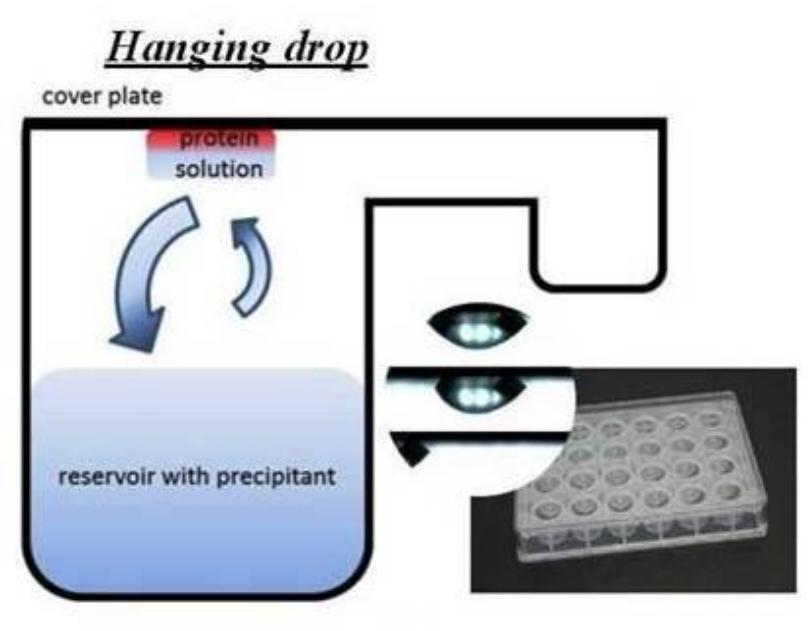

(A)

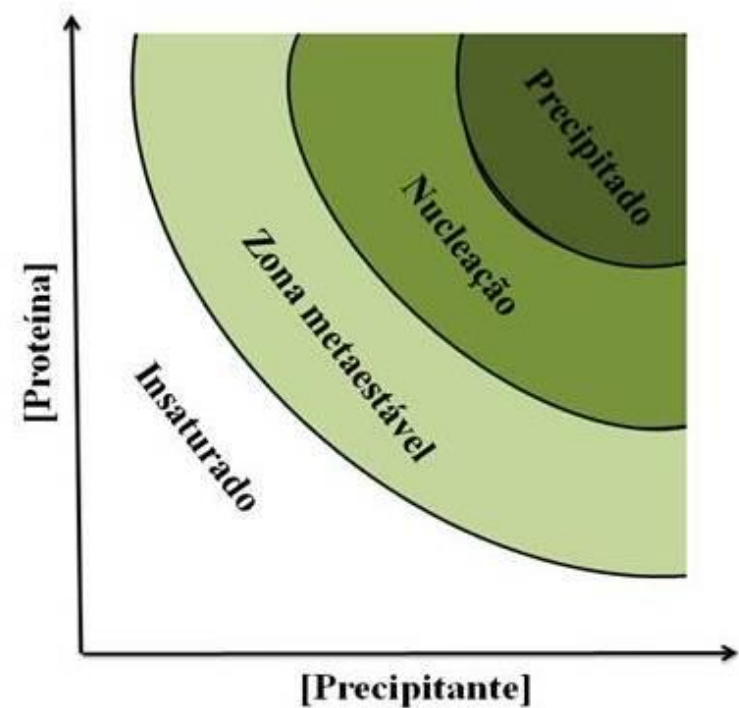

(B)

Figura 12 - Esquema para cristalização de proteínas. Em A, está ilustrado o método de gota pendurada hanging drop. Nesse método a gota fica pendurada em uma lâmina siliconizada, quando o equilíbrio é atingido os cristais começam a crescer na gota. Em B, pode-se visualizar o diagrama de fases para uma condição de cristalização, o diagrama é dividido em quatro zonas: zona insaturada, zona metaestável, nucleação e precipitado.

Fonte: Elaborada pela autora.

Os ensaios de cristalização foram realizados com o PPARy LBD, em sua forma apo e previamente incubado com os cinco ligantes selecionados. Para isto, foram utilizadas alíquotas de proteína na concentração de $10 \mathrm{mg} / \mathrm{mL}$. Os ligantes utilizados foram diluídos em DMSO e incubados com a proteína em um excesso de aproximadamente três vezes molar do ligante, mantendo o cuidado de não exceder uma concentração final de DMSO de 5 a $6 \%$. A técnica utilizada foi de gota pendurada (hanging drop). A gota era formada por $1 \mu \mathrm{l}$ da solução da proteína e $1 \mu \mathrm{l}$ da solução de cristalização. Foram utilizados kits de cristalização Crystal Screen I e II, PEG I e I/ da Hampton Research, para a montagem com estes kits utilizou-se o robô de cristalização Honeybee (Genomic solutions).

$\mathrm{Na}$ busca de melhores condições de cristalização foram feitos refinamentos em tornos das condições, variando-se a concentração de citrato de sódio de $0,8 \mathrm{M} \mathrm{a}$ 1,5M, concentração de Tris- $\mathrm{HCl}$ entre $25 \mathrm{mM}$ e $100 \mathrm{mM}$, HEPES $100 \mathrm{mM}$ e pH 7,08,0 . Todos os experimentos foram mantidos na temperatura de $18^{\circ} \mathrm{C}$. 


\subsection{Coleta e processamento dos dados de difração de raios-x}

Previamente à coleta de dados, os cristais de PPARy LBD, foram crioprotegidos com $15 \%$ de etileno glicol e coletados a temperaturas criogênicas (100 K), em fluxo de vapor de nitrogênio. Os dados de difração de raios-X foram coletados na linha de luz de cristalografia de proteínas MX-2, Laboratório Nacional de Luz Sincrotron em Campinas (LNLS), com detector Marmosaic-225 CCD (MarUSA), usando um comprimento de onda típico de 1,45866 $\AA$, respectivamente. Diversos testes preliminares também foram realizados na fonte caseira Rigaku UltraX-18 equipada com detector Mar 345 image plate, localizado no Instituto de Física de São Carlos.

Os conjuntos de dados foram obtidos através do método de rotação $(\Delta \varphi)$. A indexação das primeiras imagens e as estratégias de coleta, para determinar a orientação do cristal, os parâmetros de cela (as dimensões da cela unitária a, b e c e os ângulos $\alpha, \beta, \gamma$ ), além de determinar o grupo pontual, que designa a simetria do cristal, e estimar a mosaicidade foram realizadas pelo programa XDS. ${ }^{119}$ Esse passo é necessário para que se planeje uma estratégia eficiente de coleta de dados, minimizando o tempo de exposição do cristal ao feixe de raios- $X$, ângulo de oscilação, distância da placa ao detector, fazendo com que se maximize a qualidade dos resultados.

A integração dos dados, as reflexões observadas e eventualmente, o refinamento dos parâmetros cristalinos também foram processadas e reduzidas utilizando o programa XDS. ${ }^{119}$ Para o processamento do conjunto foram realizados o refinamento da cela unitária e a integração das imagens de difração, que consiste em quantificar a intensidade de cada ponto de difração resultando em uma lista de índices de Miller (hkl), com a intensidade de cada reflexão individual que foi medida. Para o escalonamento das intensidades e o agrupamento de todos os dados foi utilizado o programa AIMLESS ${ }^{120}$ do pacote $\mathrm{CCP}^{121}$ que consiste em escalonar e agrupar as intensidades das reflexões equivalentes relacionadas por simetria, buscando corrigir diferenças nas intensidades devido por exemplo a absorção de raios difratados e à variação da radiação incidente. O número de moléculas presentes na unidade assimétrica foi estimado utilizando o programa Matthews_coeff. ${ }^{122}$ 


\subsection{Obtenção da estrutura cristalográfica e refinamento}

As estruturas cristalográficas foram resolvidas pelo método de substituição molecular utilizando o programa PHASER. ${ }^{123}$ Foi utilizado como molde estrutural as coordenadas da estrutura depositada no PDB ${ }^{124}$ com código de acesso $3 S Z 1 .{ }^{125}$ Comumente esse método baseia-se na utilização de um modelo estrutural de uma proteína com identidade sequencial geralmente de $30 \%$ ou maior, que é transladado e rotacionado na cela unitária, para que a partir do modelo inicial e os dados da estrutura desconhecida observados se encontre em uma solução com o melhor ajuste entre os dados de difração calculados. Nesse processo se busca encontrar a melhor concordância entre a estrutura real e o modelo proposto. Essa concordância deve-se refletir numa igualdade entre os fatores de estruturas observados $\left(F_{o b s}\right)$ e os fatores de estrutura calculados $\left(F_{\text {calc }}\right)$.

Os programas PHENIX e $\mathrm{COOT}^{126-128}$ foram utilizados alternadamente para a realização de ciclos de refinamento e para a construção do modelo. Para o acompanhamento da qualidade do refinamento os parâmetros mais comuns

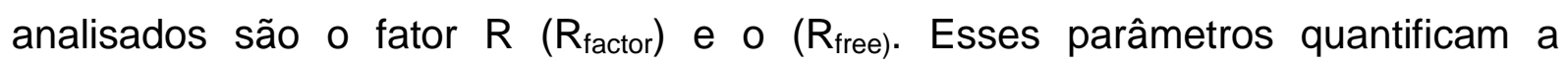
concordância entre o modelo estrutural que está sendo refinado e os dados de difração de raios- $X .{ }^{129} A$ validação da estrutura cristalográfica foi feita utilizando o programa MolProbity. ${ }^{130}$ Após a obtenção da estrutura com modelo estrutural satisfatório para os dados cristalográficos os contatos interatômicos da proteínaligante, a análise e produção das figuras com as interações no sítio ativo foram realizadas pelo programa PyMOL (The PyMOL Molecular Graphics System, Version 1.5.0.4 Schrödinger, LLC). 


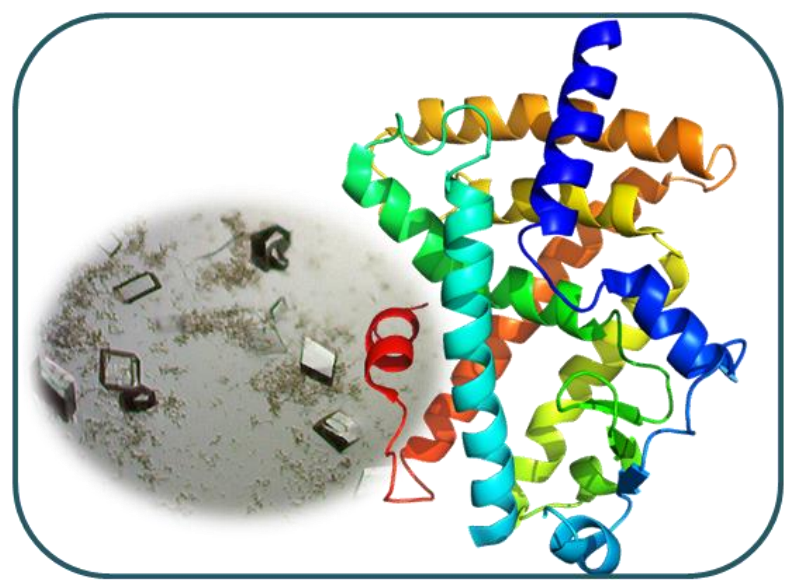

Capítulo 4

\author{
Resultados $\boldsymbol{e}$ \\ Discussão
}

Cristalografia - Análises estruturais do PPAR $\gamma$-LBD em complexo com o Ligante 3 


\section{RESULTADOS E DISCUSSÃO}

\subsection{Cristalografia}

\subsubsection{Expressão e purificação do domínio LBD do PPARy}

O PPARY LBD foi expresso em bactérias E. coli conforme descrito no item 4.1 , os procedimentos empregados para os testes iniciais de expressão foram adaptados de protocolos já utilizados para receptores nucleares, porém com algumas modificações. A purificação da proteína foi realizada em duas etapas: i) cromatografia de afinidade utilizando um gradiente de imidazol, a Figura 13 corresponde ao gel SDS-PAGE 15\% do PPARy LBD. Utilizou-se a segunda etapa, pois esta não foi suficiente para a remoção dos contaminantes. ii) cromatografia por exclusão de tamanho, no qual garantiu uma melhor separação entre as proteínas contaminantes e a proteína de interesse, onde são separadas por tamanho (massa molecular).

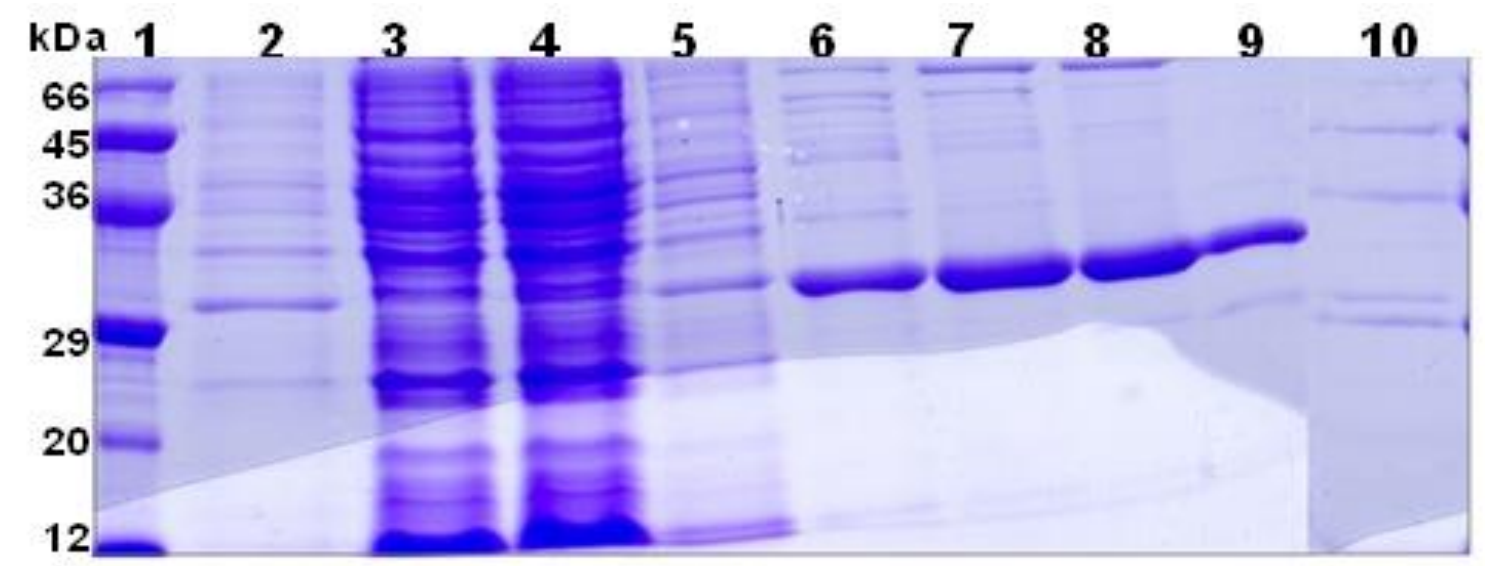

Figura 13 - Gel de poliacrilamida 15\%indicando a expressão em larga escala e purificação do domínio LBD do receptor PPARY de origem humana. Poço 1- marcador de peso molecular; 2-meio induzido; 3-produto não ligado a matriz 1 (flow through), 4- flow through 2; 5-tampão de lavagem sem imidazol; 6-tampão de lavagem $+5 \mathrm{mM}$ de imidazol; 7-tampão de lavagem + 10mM de imidazol; 8-tampão de lavagem $+20 \mathrm{mM}$ de imidazol; 9-tampão de lavagem + 40mM de imidazol e 10-tampão de lavagem + 200mM de imidazol.

Fonte: Elaborada pela autora.

A Figura 14 mostra o perfil cromatográfico da purificação por exclusão de tamanho, a proteína de interesse apresentou um pico predominante, no qual o PPARy eluiu na coluna em um volume de $70 \mathrm{~mL}$ que corresponde às proteínas de 
massa de aproximadamente $30 \mathrm{kDa}$ segundo a calibração da coluna com proteínas de massa molecular conhecidas (dados não demonstrados). A pureza da amostra foi confirmada por SDS-PAGE 15\% (Figura 14 inserto). O rendimento da purificação foi cerca de $30 \mathrm{mg} / \mathrm{L}$ de cultivo e as proteínas foram concentradas até $10 \mathrm{mg} / \mathrm{mL}$ e armazenadas a $-80^{\circ} \mathrm{C}$ para posterior ensaios de cristalização.

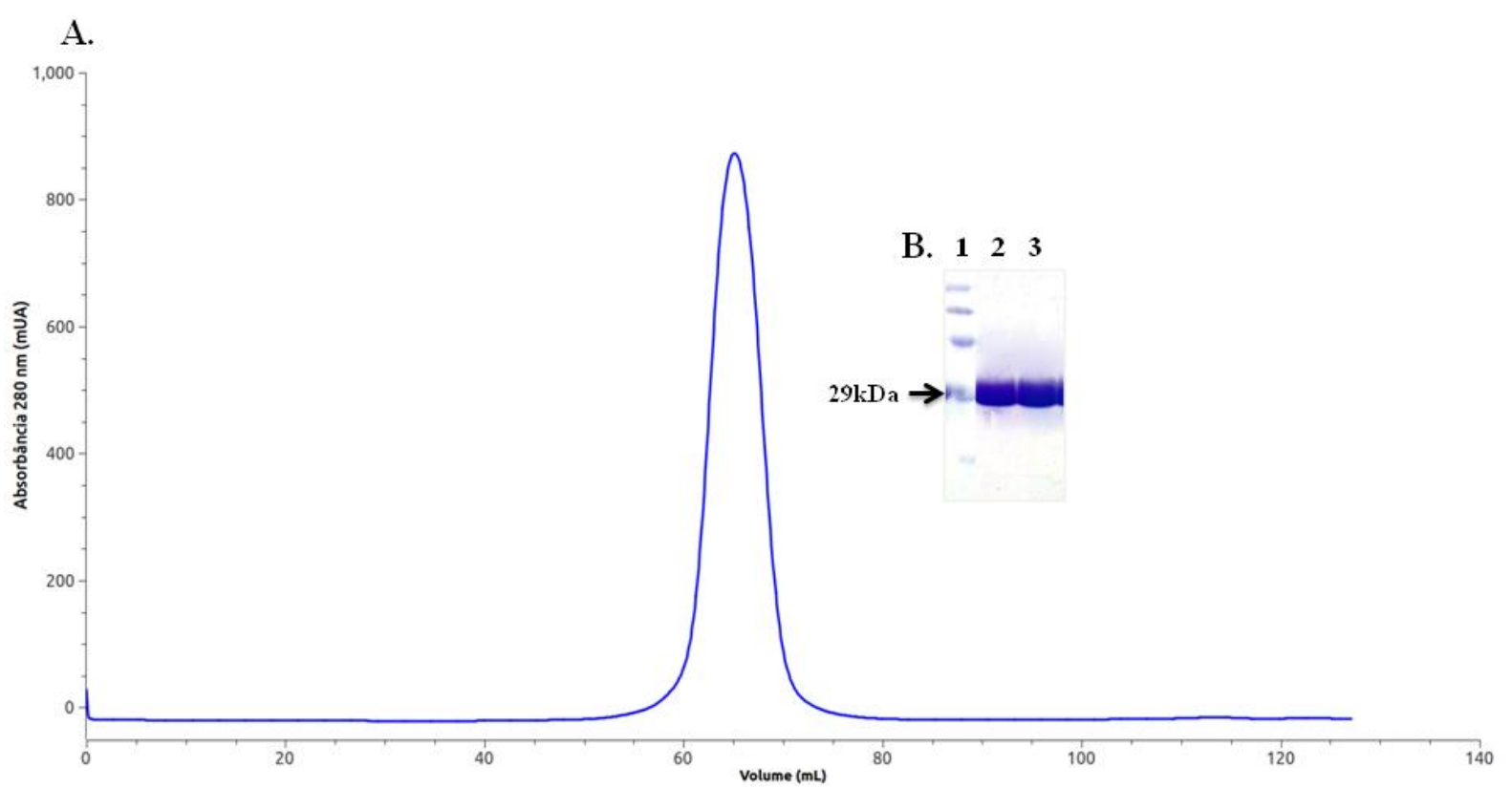

Figura 14 - Perfil cromatográfico do PPARY LBD após a purificação por afinidade, as frações referentes ao pico de PPARY foram coletadas, concentradas e analisadas por SDSPAGE $15 \%$.

Fonte: Elaborada pela autora.

Foi realizado um screening de cristalização para os 5 ligantes selecionados previamente neste trabalho, utilizou-se para todos estes ligantes diferentes concentrações de agentes tamponantes e diferentes pHs, porém não obtivemos cristais de boa qualidade e que apresentassem um padrão de difração adequado para a realização da técnica de difração de Raios- $X$ para o ligante 1,2 e 5. A seguir serão apresentados os dados obtidos para o ligante 3 e 4.

\subsection{Análises Estruturais do PPARy-LBD em Complexo com o ligante 3}

\subsubsection{PPARY com o Ligante 3}

O ligante 3 possui em sua estrutura o grupo tetrazol, no qual é formado por um anel de quatro átomos de nitrogênio e um átomo de carbono (Figura 15). 
Este complexo e os 4 demais como já foi mencionado foram caracterizados como ligantes do PPARy em um trabalho de docking realizado pelo nosso grupo. Casimiro-Garcia e colaboradores ${ }^{65}$ identificou este grupo funcional como ligante do PPARy e presente nos agonistas do PPARy. Com isso a busca por estruturas do PPARY complexados com ligantes tetrazóis foi realizada.

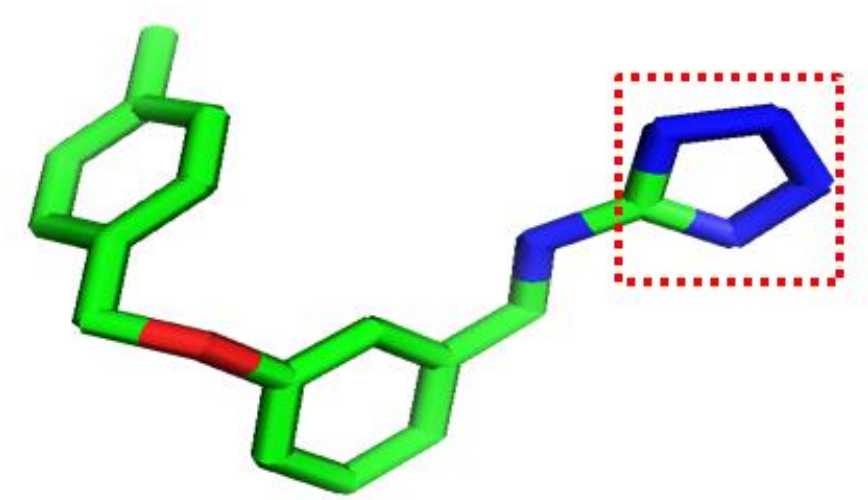

Figura 15 - Estrutura química do ligante 3, em vermelho evidenciando o grupo tetrazol.

Fonte: Elaborada pela autora.

\subsubsection{Testes de cristalização, coleta e processamento dos dados do PPARY com o Ligante 3}

Diversas condições de cristalização foram realizadas para o complexo $3 \mathrm{com}$ PPARY-LBD, como descrito na seção 3.5. As condições que mais apresentavam indícios de formação de cristais era aquelas que continham Tris- $\mathrm{HCl}$ como tampão e pHs que variavam de 7,0 a 8,0. A otimização dessas condições resultou na formação de cristais mais morfologicamente regulares e cristais maiores. $\mathrm{O}$ cristal selecionado para a coleta de difração de raios- $X$ cresceu na condição de $0,9 \mathrm{M}$ de citrato de sódio, 100 mM de Tris-HCl pH7,0 Figura 16A.

Para a coleta de dados, os cristais foram imersos em solução crioprotetora contendo etileno glicol a $15 \%(\mathrm{v} / \mathrm{v})$. Logo após, os mesmo foram resfriados diretamente no vapor de nitrogênio líquido a $100 \mathrm{~K}$ e mantidos durante toda a coleta nessa temperatura. Foram obtidos imagens bem definidas resultante do espalhamento de raios- $X$ e padrões de difração que apresentavam rede cristalina única para o cristal de PPARY-LBD com o ligante 3. 


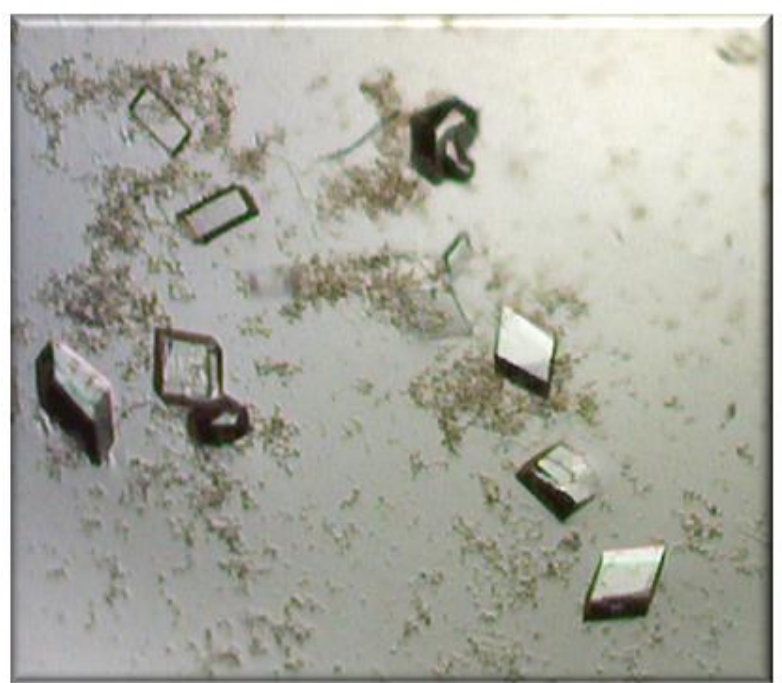

(A)

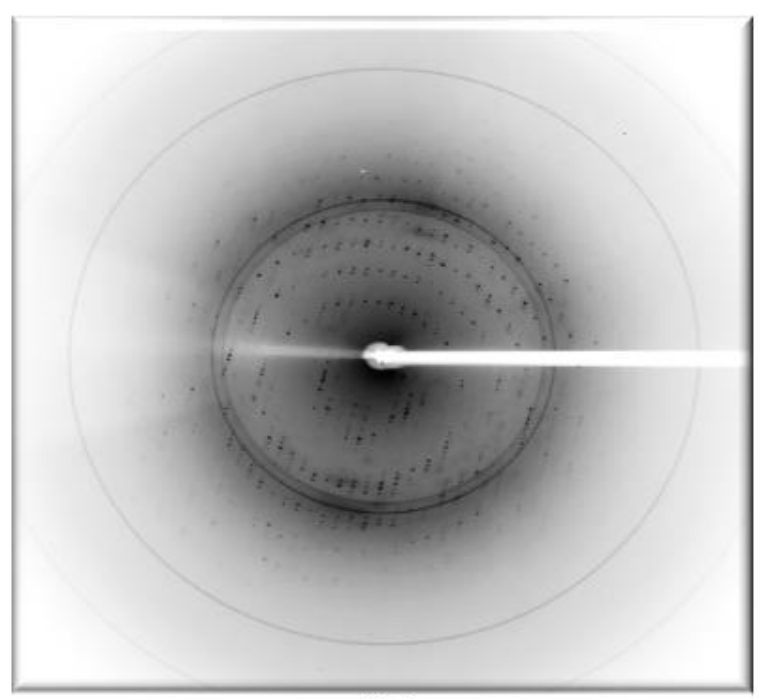

(B)

Figura 16 - A. Cristais do complexo 3 crescido na condição de $0,9 \mathrm{M}$ de citrato de sódio, $100 \mathrm{mM}$ de Tris- $\mathrm{HCl}$ pH 7,0. B. Padrão de difração do PPARy em complexo com o ligante $3 \mathrm{com}$ difração a $2,2 \AA$.

Fonte: Elaborada pela autora.

Na Figura 16B mostra a imagem do padrão de difração para o conjunto coletado. O conjunto não apresentou anel de gelo que prejudicassem um processamento inicial simples e as reflexões vistas são características da difração por uma rede cristalina de proteína. Após a coleta, indexação, integração e escalonamento das imagens foram obtidos as estatísticas de coleta e dados do refinamento que estão resumidas na Tabela 1.

O cristal do PPARY-LBD com o ligante 3 teve os dados processados no grupo espacial C2 e coletado a uma resolução máxima de $2.2 \AA$. Duas moléculas foram observadas na unidade assimétrica, denominadas cadeia $A$ e $B$, o que foi confirmado após a substituição molecular feita no programa PHASER utilizando como modelo a estrutura 3DZY do PDB como molde. 
Tabela 1 - Estatísticas cristalográficas de coleta e refinamento do PPARy-LBD com o complexo 3.

\begin{tabular}{|c|c|}
\hline Parâmetros & PPARy-complexo 3 \\
\hline Comprimento de onda/Linha & $1,459 /$ LNLS-MX2 \\
\hline Resolução $(\AA)$ & $45,3-2,2(2,2-2,2)$ \\
\hline Grupo espacial & C2 \\
\hline Cela unitária & $\begin{array}{c}92,7 ; 62,1 ; 118,2 \AA \\
B 101.9^{\circ}\end{array}$ \\
\hline Número de reflexões únicas & $31871(2805)$ \\
\hline Multiplicidade & $3,5(3,0)$ \\
\hline Completeza (\%) & $94,7(84,1)$ \\
\hline$<\mathrm{l} / \sigma(\mathrm{l})\rangle$ & $16,2(2,5)$ \\
\hline B-factor médio & $35 \pm 30$ \\
\hline R-merge* & $0,08686(0,406)$ \\
\hline $\mathrm{CC} 1 / 2$ & $0,978(0,775)$ \\
\hline CC $^{*}$ & $0,995(0,934)$ \\
\hline R-factor / R-free & $0,2598(0,7311) / 0,3085(0,7649)$ \\
\hline Macromoléculas & 3860 \\
\hline Ligante & 22 \\
\hline Água & 74 \\
\hline Proteínas & 513 \\
\hline RMSD (ligação) Å & 0,008 \\
\hline RMSD (ângulo)ํำ & 1,13 \\
\hline Ramachandran plot (\%) & 0 \\
\hline Região favorável & 97 \\
\hline Região permitida & - \\
\hline Regiăo nã́o permitida & 0,2 \\
\hline Clashscore & 10,24 \\
\hline B-factor médio & 60,90 \\
\hline Macromoléculas & 60,90 \\
\hline Ligante & 74,40 \\
\hline Solvente & 54,90 \\
\hline
\end{tabular}

${ }^{*}$ Rmerge $=\sum \mathrm{hkl} \sum \mathrm{i}|l(\mathrm{hkl})-</(\mathrm{hkl})>| l \sum \mathrm{hkl} \sum \mathrm{i}</(\mathrm{hkl})>$, onde $l(\mathrm{hkl})$ é a intensidade observada para $l(h k l)$ e $<l(h k l)>$ é a média das intensidades

Fonte: Elaborada pela autora.

\subsubsection{Análise estrutural do PPARy com o Ligante 3}

A estrutura tridimensional do PPARY-LBD complexado com o ligante 3 como já foi descrito anteriormente para outras estruturas do PPARY, consiste de $13 \alpha$ hélices que formam um sanduíche de três camadas antiparalelas de $\alpha$-hélices com três pequenas fitas- $\beta .{ }^{131,132}$ Foi observado que o complexo 3 se liga ao bolsão de ligação da cadeia $B$ do PPARY (Figura 17). A hélice 12 apresenta uma conformação ativa (H12 fechada) na cadeia $A$ e a cadeia $B$ mantém-se numa conformação inativa 
(H12 aberta). Esta conformação inativa é devido aos contatos cristalinos com os resíduos vizinhos da molécula simétrica da cadeia $A$, provavelmente estas interações impedem uma mudança para a conformação ativa.
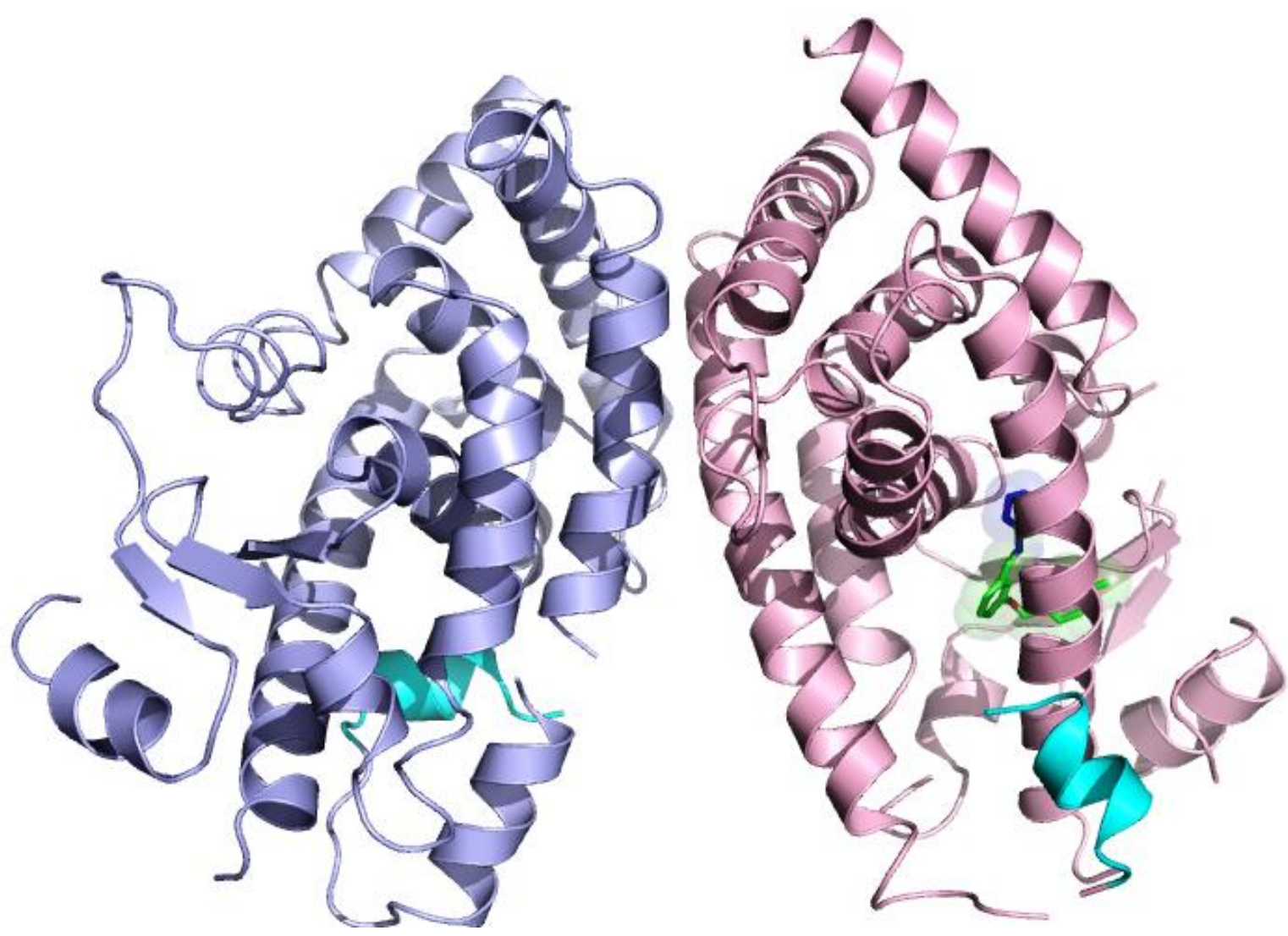

Figura 17 - Representação do dímero do PPARY-LBD complexada com o ligante 3. As hélices- $\alpha$ da cadeia A estão representadas em lilás e as da cadeia B em rosa, as $\mathrm{H} 12$ estão representadas em ciano, o ligante está representado em verde e sticks.

Fonte: Elaborada pela autora.

O ligante 3 interage com o PPARy por meio de interações hidrofóbicas e estabiliza a folha- $\beta$ através de uma ligação de hidrogênio entre o grupo tetrazol do ligante e a molécula de água. Esta molécula de água estabiliza o ligante em todas as demais ligações de hidrogênio. $O$ anel tetrazol do ligante está rotacionado para a direção da $H 3$. Essa ocupação do ligante faz com que ele faça duas ligações de hidrogênio com o NH1 e NH2 da R 288, sendo esta uma forte interação polar. Essa ligação faz com que a $\mathrm{H} 12$ não faça importantes interações, alterando visivelmente o modo de ligação do complexo 3. A distância entre a molécula de água e o átomo $\mathrm{NH} 1$ do anel tetrazol do ligante é de $3,2 \AA$, a outra ligação de hidrogênio com a água e a L228 tem uma distância de 2,8 $\AA$. Na Figura 18 pode ser visto o mapa de 
densidade eletrônica em torno do ligante 3 e dos aminoácidos que estão fazendo as interações e na Figura 19 as ligações de hidrogênio em destaque.

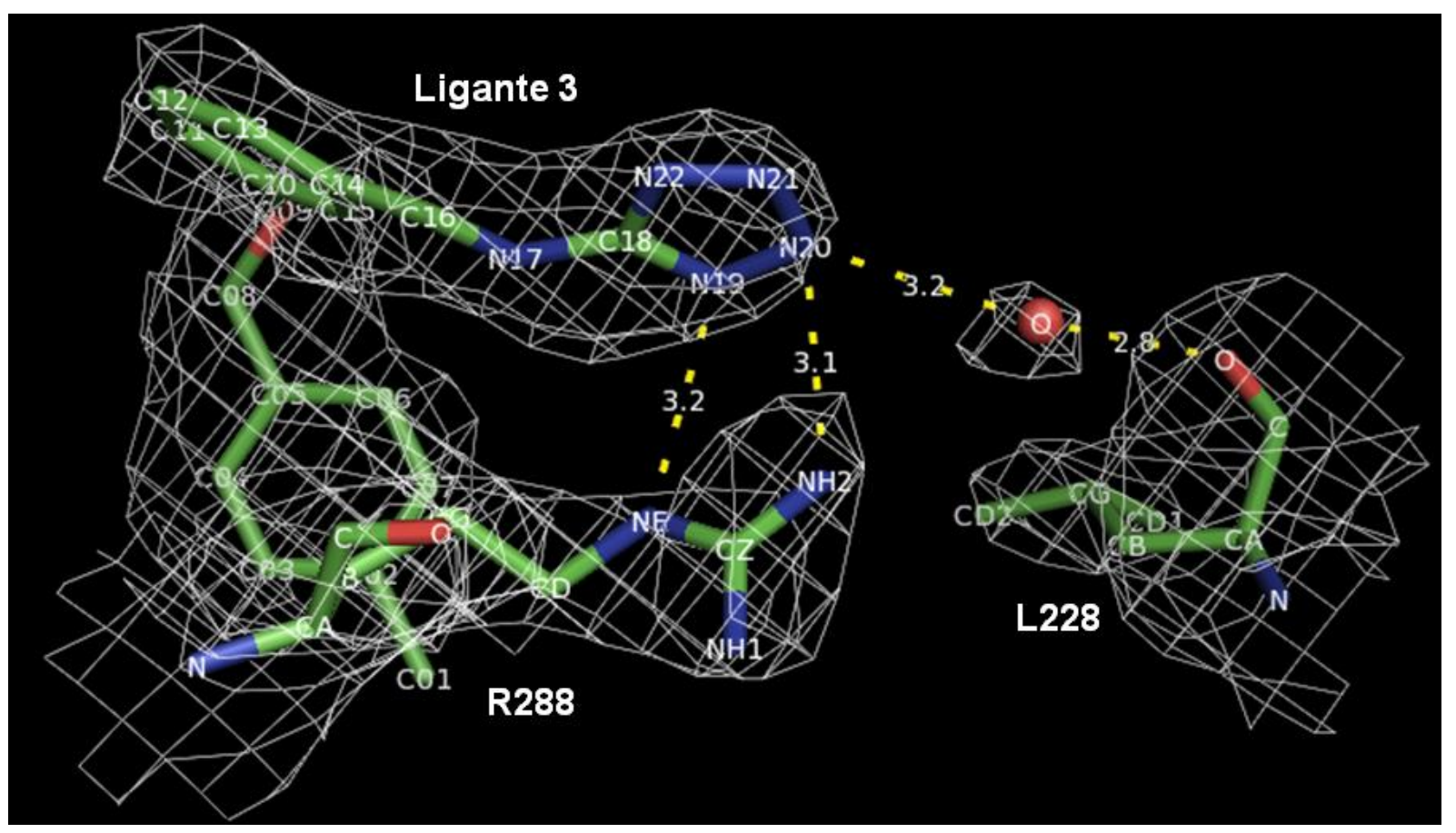

Figura 18 - Nesta figura está evidenciado o omit map do ligante 3 em $2 F o-F c$, o contorno mostrado para o ligante é de 1,0б. Em linhas tracejadas está mostrando as ligações de hidrogênio com suas respectivas distâncias.

Fonte: Elaborada pela autora. 


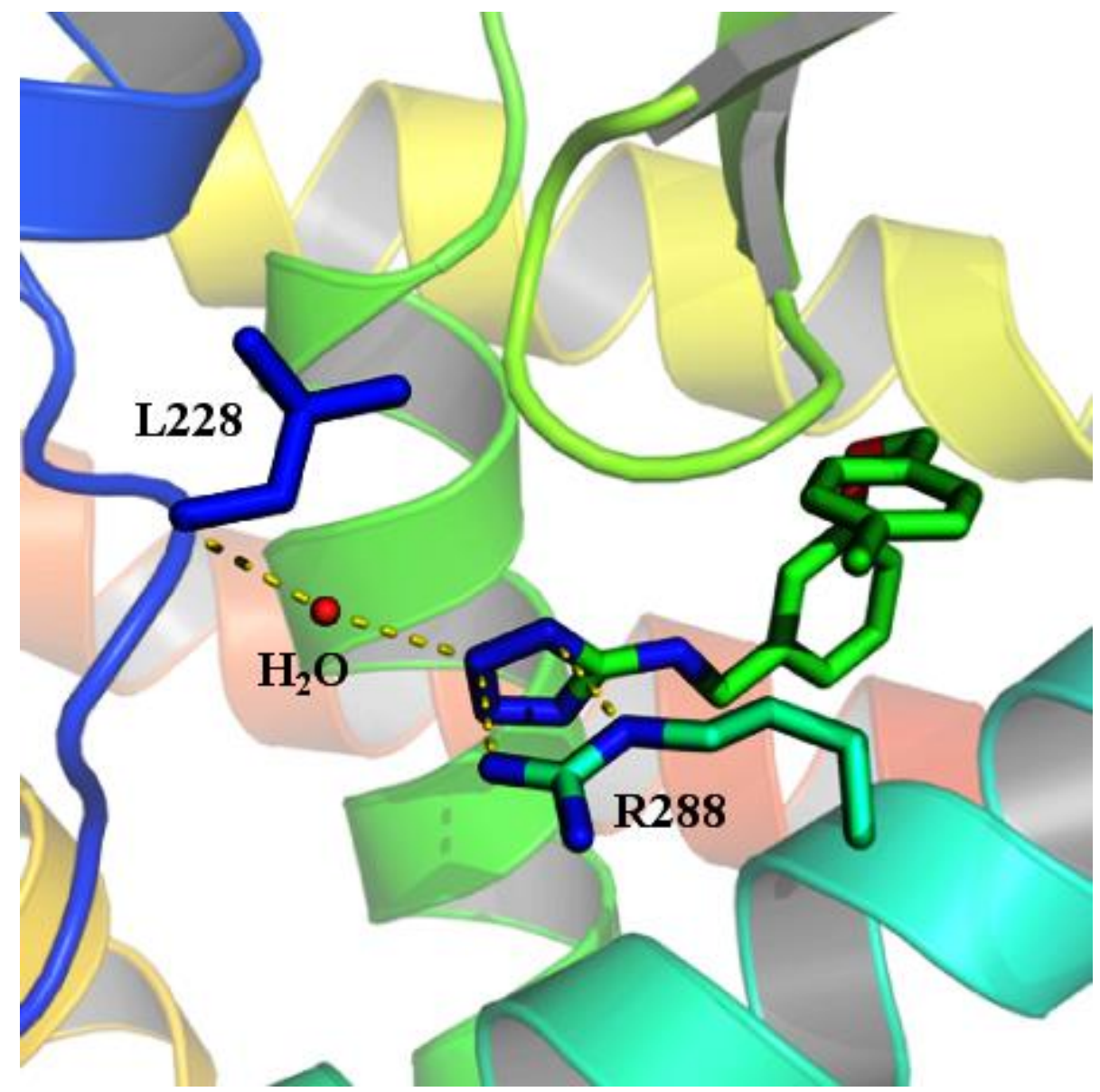

Figura 19 - Detalhes estruturais do complexo PPARY-LBD com o ligante 3 na conformação inativa (cadeia B), as linhas tracejadas em amarela indicam as ligações de hidrogênio.

Fonte: Elaborada pela autora.

Quando se faz uma análise das interações entre o PPARy e o complexo 3 nota-se que o ligante não interage diretamente com a Tyr 473, (como descrito na seção 1.7 para agonistas totais), ou seja o complexo 3 está localizado entre a hélice $\mathrm{H} 3$ e as fitas $\beta$ e tem sido demonstrado que essa região é ocupada por agonistas parciais sintéticos. ${ }^{30,58}$ Os agonistas totais como a rosiglitazona se ligam em uma conformação em forma de $U$ com a cabeça polar se estendendo em direção a hélice AF-2 para formar uma ligação de hidrogênio com o grupo hidroxila da cadeia lateral da Tyr 473 e dessa forma fechar a $\mathrm{H} 12$ em uma conformação ativa. Além da Tyr 473, duas histidinas H323 e H449 participam na fixação da TZD ${ }^{59}$ (Figura 20).

O complexo 3 se liga ao PPARY de maneira diferente da rosiglitazona, pois ela ocupa uma região delimitada pela $\mathrm{H} 3$ e fitas $\beta$ e está localizada a uma distância considerável da $\mathrm{H} 12$, não interagindo com os resíduos da $\mathrm{H} 12$ que na forma ativa estabiliza o receptor, o que é característico dos agonistas como as TZDs. Quando a 
estrutura cristalográfica com o complexo 3 é sobreposto com a estrutura com a rosiglitazona 2PRG (Figura 21), demonstra que não é possível a acomodação dos ligantes simultaneamente.

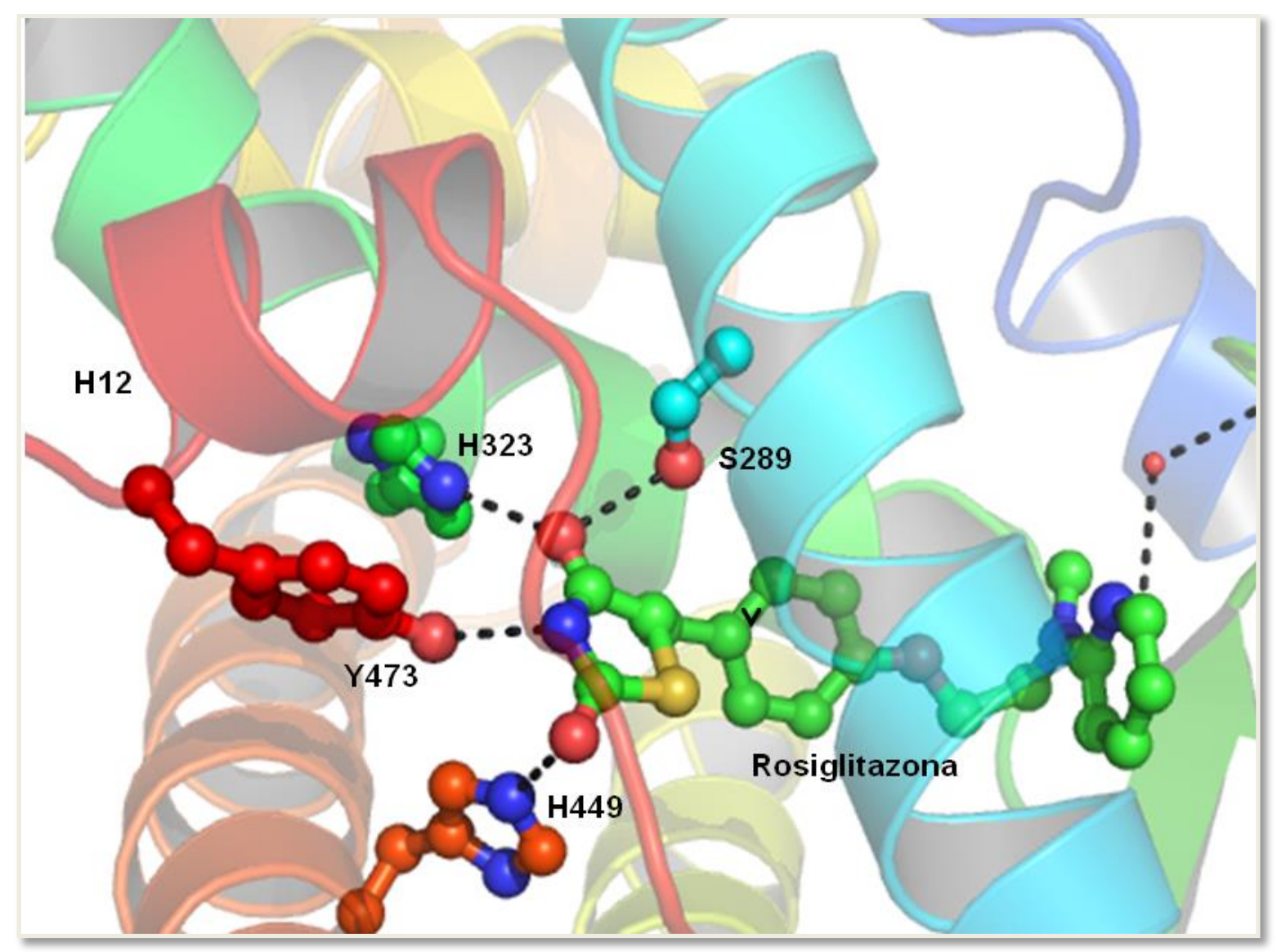

Figura 20 - Padrão das interações da rosiglitazona (PDB:2PRG).

Fonte: Elaborada pela autora.

O modo de ligação descrito para o ligante 3 permite classificá-lo no grupo de ligantes que não interagem diretamente com a H12, descritos como agonistas parciais na seção 1.7, estabilizando as fitas- $\beta$ por meio de interações hidrofóbicas. ${ }^{84}$ Este padrão de ligação também é visto para agonistas parciais como INT131 ${ }^{132}$ que necessita de uma molécula de água para mediar o contato com Tyr 473 da H12. O agonismo parcial do INT131 resulta em uma redução dos efeitos colaterais característicos dos agonistas totais TZD e redução nos níveis de glicose sem causar edemas. ${ }^{132}$ Além dos agonistas parciais MRL-24 e o GQ-16 ${ }^{55}$ que bloqueiam a fosforilação da S273 pela CdK5. Quando se faz uma sobreposição entre o complexo 3 e um dos agonistas parciais, o MRL24, podemos notar a semelhança na estrutura tridimensional entre eles, incluindo a $\mathrm{H} 12$ e a acomodação dos ligantes por meio das 
interações hidrofóbicas semelhantes entre estes agonistas (Figura 22). Além das semelhanças nas regiões das ligações de hidrogênio hidrofóbicas.

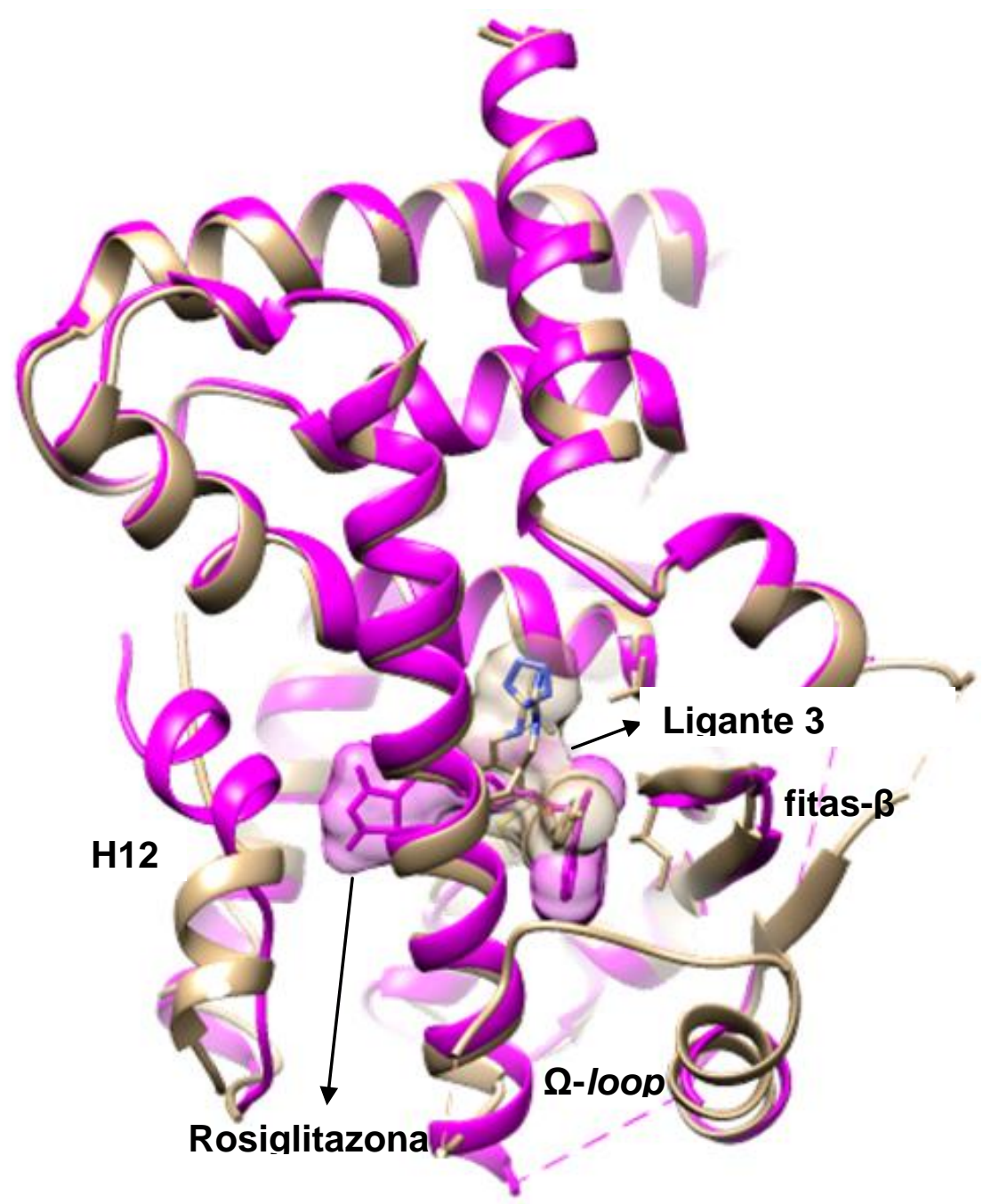

Figura 21 - Sobreposição da estrutura do PPARY complexado com o ligante 3 (dourado) e do PPARY complexado com a rosiglitazona (pink).

Fonte: Elaborada pela autora. 


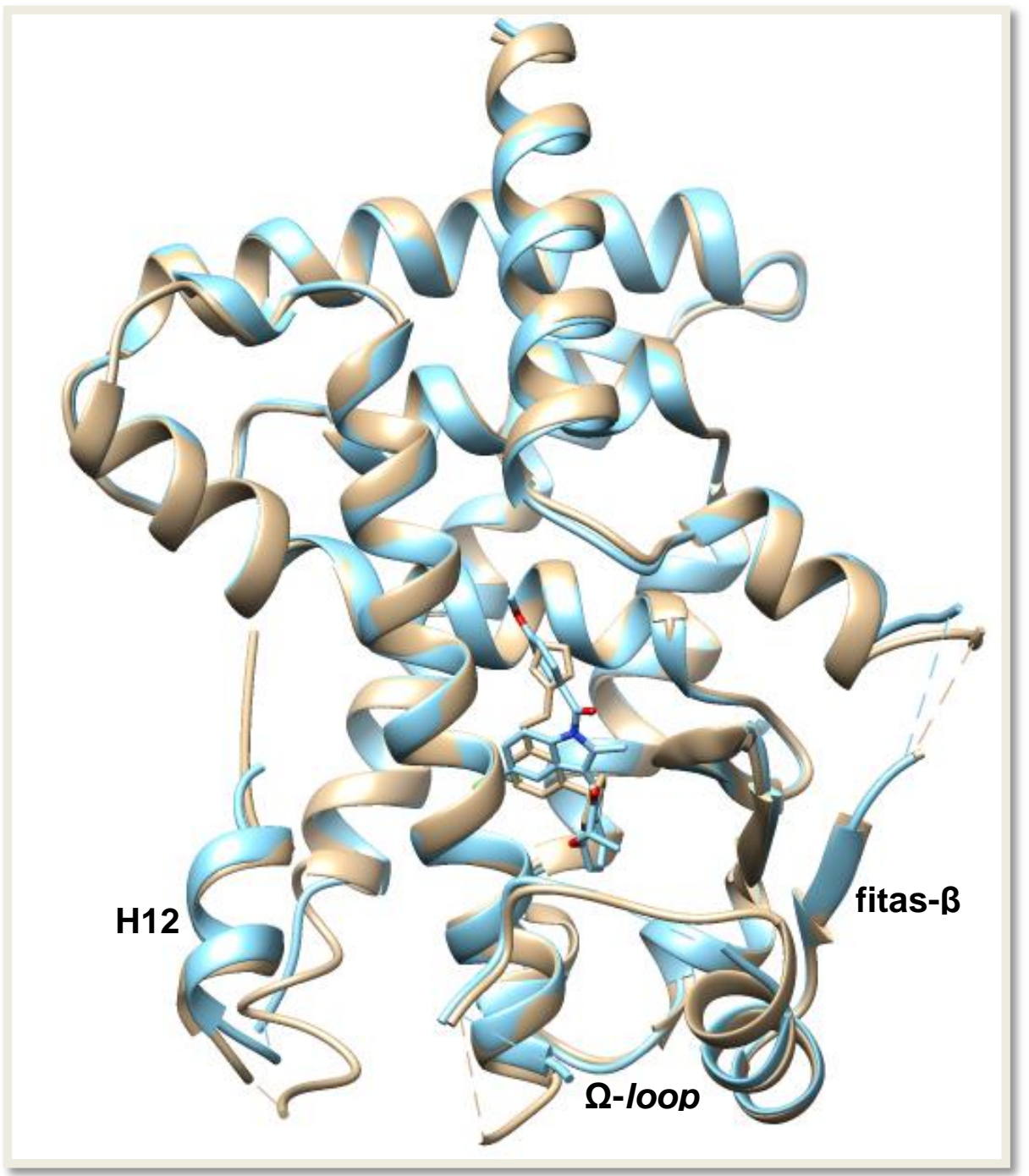

Figura 22 - Sobreposição do complexo 3 em dourado com o agonista parcial MRL-24 em azul (2Q5P).

Fonte: Elaborada pela autora.

A ocupação do complexo 3 pode levar diferenças na estabilização das cadeias $\mathrm{A}$ e $\mathrm{B}$, como podemos observar na Figura 23 do fator de temperatura ( $B$ factor), onde mostra regiões mais dinâmicas e/ou menos ordenadas. A determinação dos fatores de temperatura das estruturas cristalográficas serve como uma indicação direta da mobilidade da proteína e prevê a informação sobre a distribuição da densidade eletrônica. A espessura da linha é proporcional ao grau de movimentação da região correspondente.

Fazendo uma análise da distribuição dos fatores de temperatura do complexo 3 , mostrou que ocorre uma estabilização um pouco diferenciada entre a cadeia $\mathrm{A}$ e a cadeia B. A cadeia A apresenta uma maior estabilidade próximo a $\mathrm{H} 11$ e $\mathrm{H} 12$ se comparado com a cadeia $B$ (região que se encontra o ligante). A cadeia $B$ possui 
uma estabilização maior na região do loop entre a H2 e H2' entre a região das fitas- $\beta$ que pode ser explicado devido às interações hidrofóbicas que o ligante faz nessa região e exerce um papel na estabilização de regiões específicas da estrutura da proteína. Pode-se dizer que a atividade transcricional para um ligante não se restringe pela presença ou ausência de interações diretas com a H12, mas sim pelo modo de ligação ao receptor.

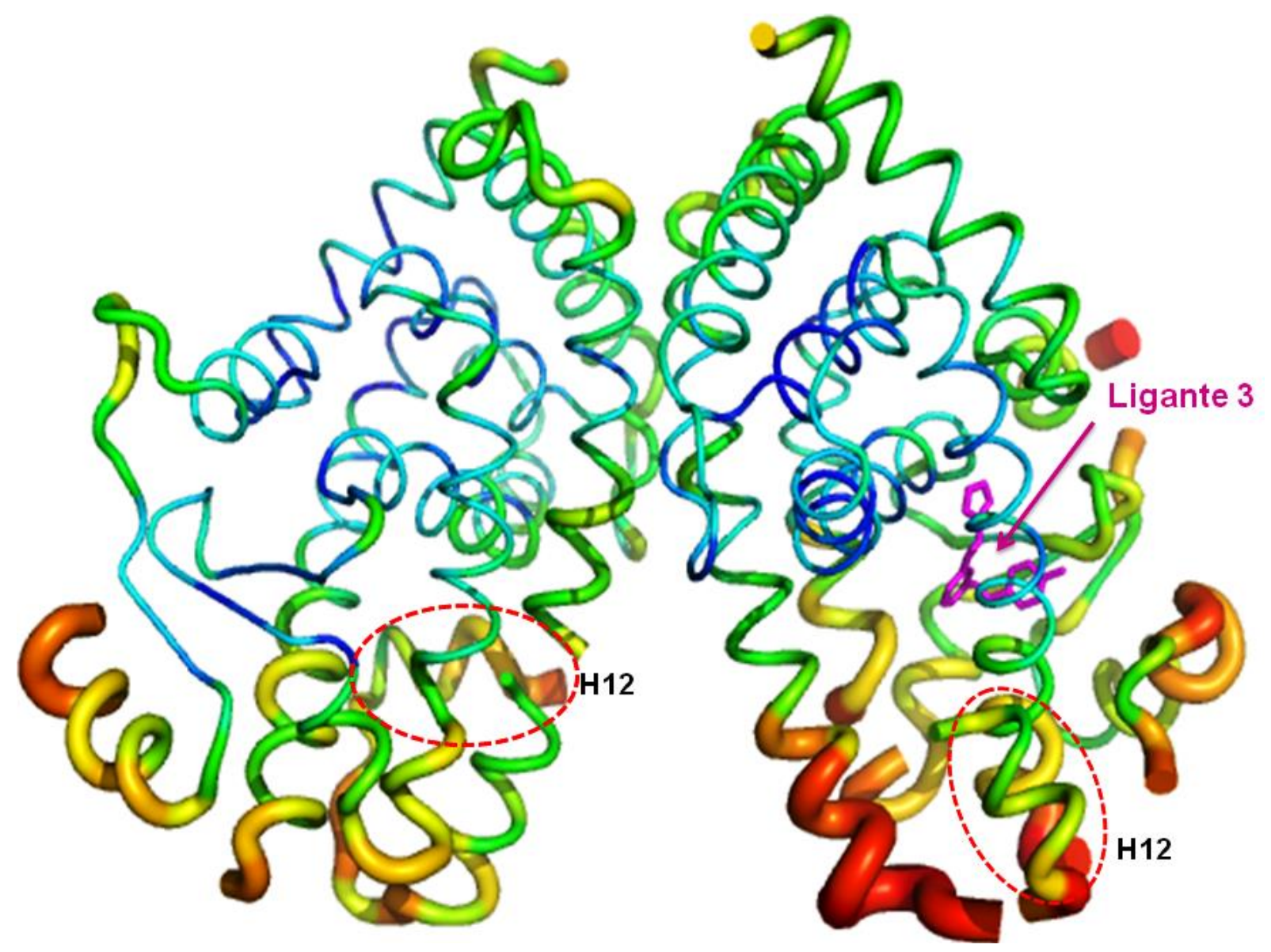

Figura 23 - Distribuição dos fatores de temperatura da cadeia A e da cadeia B do complexo 3. A H12 está representada em linhas tracejadas em vermelho.

Fonte: Elaborada pela autora 


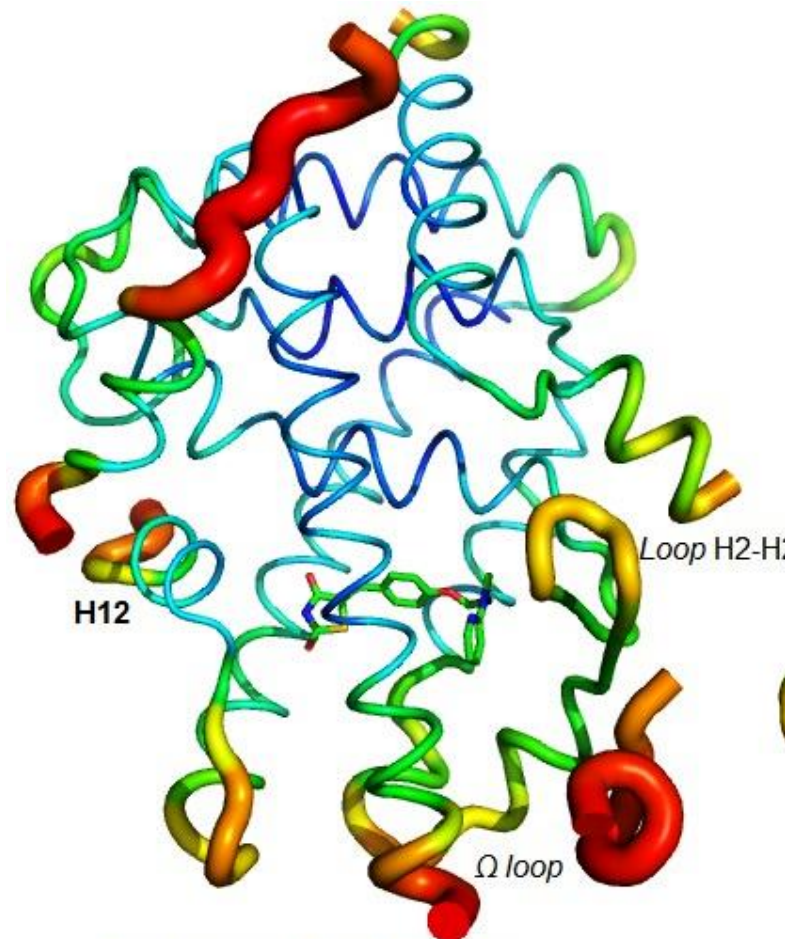

Rosiglitazona (PDB 2PRG)

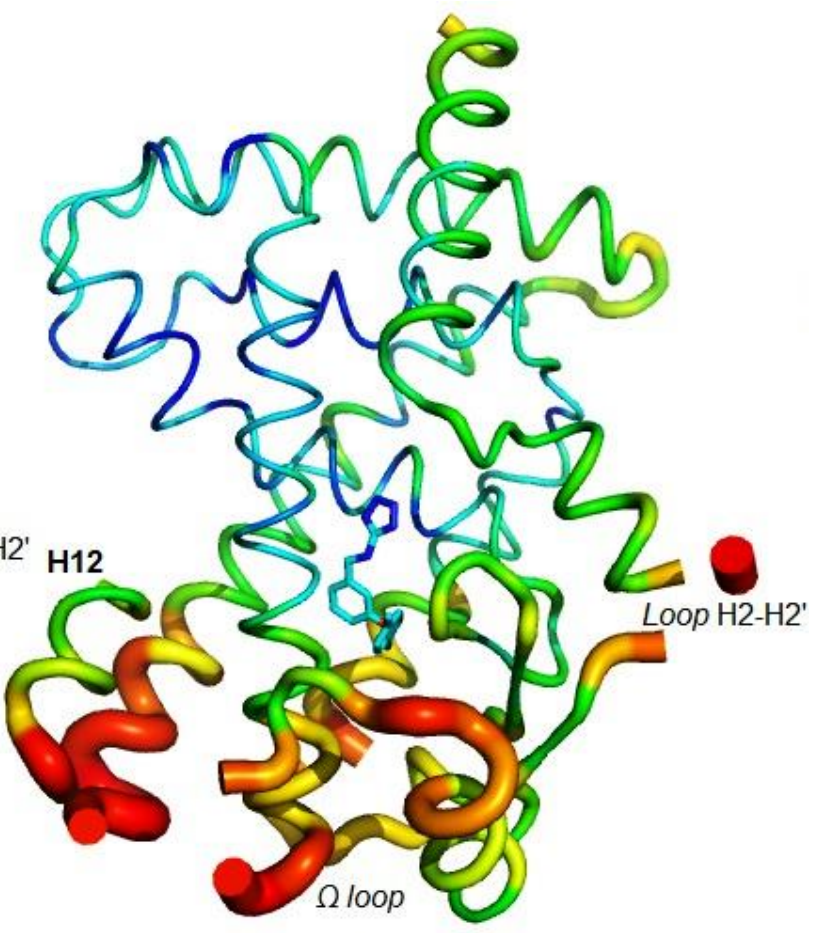

Complexo 3

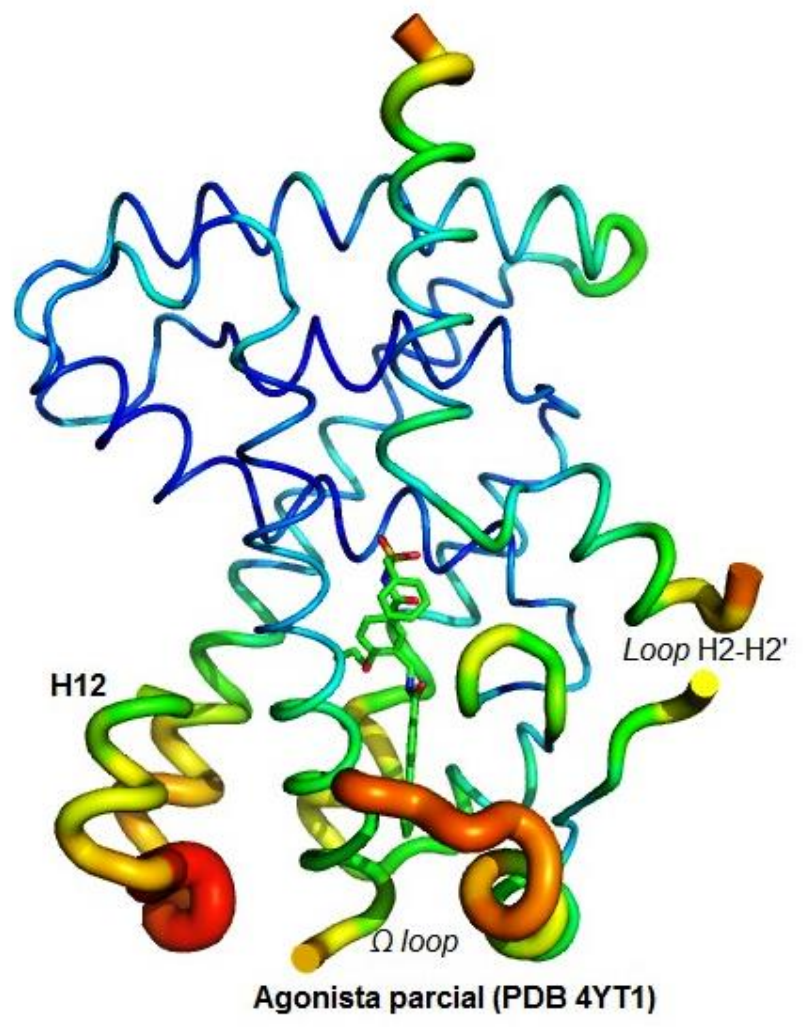

Figura 24 - Distribuição dos fatores de temperatura do agonista total rosiglitazona, do complexo 3 e do agonista parcial MEKT76 que apresenta no seu refinamento uma resolução de $2,2 \AA$ o mesmo que o complexo 3. Para todas as estruturas tridimensionais estão mostradas as cadeias $B$. 
$\mathrm{Na}$ análise da distribuição dos fatores de temperatura comparando o agonista total rosiglitazona, com os agonistas parciais, complexo 3 e MEKT76 (PDB 4YT1) a uma resolução de 2,2Å, mesma resolução que o complexo 3 (Figura 24), mostrou que ocorre uma estabilização diferenciada das estruturas quando complexadas a diferentes agonistas. Os agonistas parciais estabilizam o $\Omega$-loop, enquanto que a rosiglitazona estabiliza a $\mathrm{H} 12$. De acordo com essas análises dos fatores de temperatura foi demonstrado que a região das fitas- $\beta$, do $\Omega$-loop e a H2', são preferencialmente estabilizadas pelos agonistas parciais como o complexo 3 e 0 MEKT76 enquanto que a rosiglitazona estabiliza preferencialmente a $\mathrm{H} 11$ e $\mathrm{H} 12$, região onde se encontra os ligante. Isto também se deve pela forte interação com a Y473 (H12), que é a base estrutural para o seu comportamento agonista. ${ }^{133}$

Para as regiões estabilizadas pelos agonistas parciais como a região do $\Omega$ loop pode ser explicada por essa região ser mantida rígida devido às ligações hidrofóbicas que o ligante faz nessa região. Na região do $\beta$-hairpin dos agonistas parciais, mostra que de fato a proximidade do ligante com o $\beta$-hairpin da uma maior estabilização nessa região do que quando o ligante interage na $\mathrm{H} 12$.

\subsubsection{Adipogênese em células 3T3-L1}

Foi realizado pelo grupo do Professor do Paul Webb (The Methodist Research Institute, em Houston, TX, EUA), testes de diferenciação de adipócitos com o ligante 3 e a roziglitazona, que corroboraram com este trabalho para verificar se este ligante tetrazol é capaz de promover a adipogênese. A diferenciação de adipócitos foi realizada com as células murinas 3T3-LI, que possuem uma morfologia de fibroblastos, mas que em condições apropriadas são diferenciadas a adipócitos. Para avaliar os efeitos do ligante 3 sobre a diferenciação de adipócitos induzida pela roziglitazona, foram adicionados $1 \mu \mathrm{M}, 10 \mu \mathrm{M}$ concomitantemente com $1 \mu \mathrm{M}$ de roziglitazona.

A diferenciação das células é iniciada pela exposição destas ao coquetel adipogênico contendo isobutilmetilxantina (IBMX), que é um inibidor de fosfodiesterase competitivo e não seletivo, a dexametaxona, que é uma molécula anti-inflamatória esteróide que estimula a diferenciação osteogênica e adipogênica de maneira dependente de células, tempo e concentração e a insulina que é amplamente utilizada para induzir proliferação e diferenciação de pré-adipócitos. ${ }^{134}$ 
O IBMX em combinação com dexametasona regula o PPARY, promovendo a adipogênese. ${ }^{134}$ As células foram coradas com o corante Oil Red que é um corante que quando adicionado às culturas de células de adipócitos nos ajuda a identificar quais as que já se encontram diferenciadas, pois este corante vai tingir de vermelho os lipídios que se encontrarem nas células.

Foi possível ver que o ligante 3 tem efeitos adipogênicos em células 3T3-LI bem menor do que quando comparado com a rosiglitazona e pode-se predizer que 0 ligante 3 pode ser considerado um importante agonista parcial do PPARY (Figura 25). Além disso, para o ligante 3 espera-se que tenha um efeito hipoglicemiante in vivo sem efeito adipogênico forte como tem a rosiglitazona, uma vez que é similar ao que foi apresentado em uma patente em 1989 por Kenneth L. e colaboradores ${ }^{135} \mathrm{em}$ que a estrutura apresentada por este ligante possui um grupo tetrazol onde os testes realizados em ratos, os agentes hipoglicemiantes que apresentavam este grupo tetrazol tiveram como resultado a redução dos níveis de glicose no sangue desses ratos que sofriam de hiperglicemia e também diabetes.

(a)

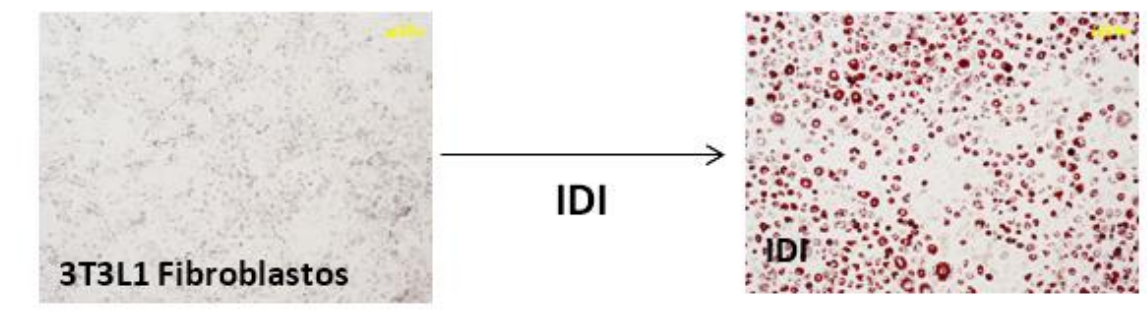

(b)

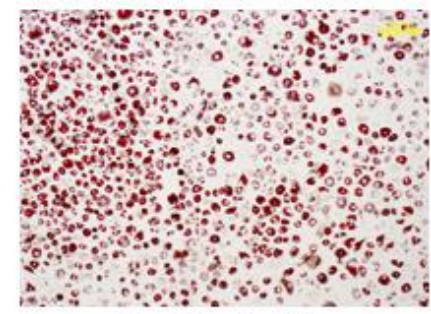

Lig. 3 a $1 \mu \mathrm{M}$

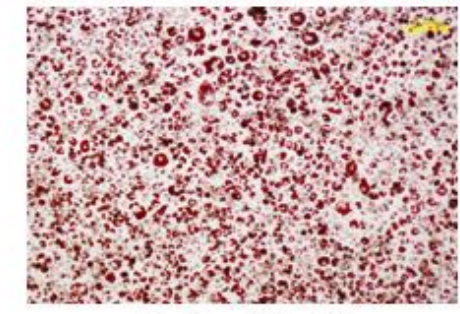

Lig. 3 a $10 \mu \mathrm{M}$

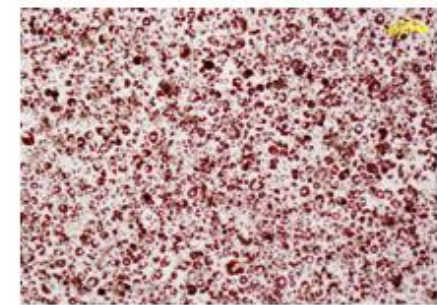

Rosi $1 \mu \mathrm{M}$

Figura 25 - Ensaio de diferenciação das células 3T3-LI com o ligante 3. A. mostra as células 3T3-LI antes da diferenciação na presença da solução de diferenciação (insulina, dexametasona e IBMX), os pré-adipócitos atingiram a morfologia de adipócitos maduros com características primárias, incluindo um grande número de gotículas lipídicas citoplasmáticas. A coloração com Oil Red O evidenciou as gotículas lipídicas com marcação vermelha. Em B as células com concentrações diferentes do ligante 3 e rosiglitazona. 


\subsubsection{Discussão}

Agonistas parciais que fazem interações independentes da $\mathrm{H} 12$ e que bloqueiam a fosforilação do PPARy mediada pela CDK5 do PPARY são outras alternativas para uma construção de uma nova classe de ligantes. ${ }^{28,55,63-64} \mathrm{O}$ aumento da taxa de fosforilação do PPARy na Ser273 pela CDK5 está associado com a resistência a insulina relacionada com a obesidade. O tratamento com rosiglitazona reduziu a fosforilação do PPARy mediada pela CDK5 em ratos. ${ }^{55}$ Esta recente descoberta que o PPARy, alvo de drogas anti-diabéticas por inibição da fosforilação mediada por Cdk5 do receptor tem proporcionado uma nova perspectiva para avaliar e talvez desenvolver agentes de sensibilização à insulina melhorados. Dois ligantes agonistas parciais foram selecionados para mostrar o bloqueio da fosforilação da S273 pela CDK5, o MRL-24 e o GQ-16. ${ }^{55,83}$ Esta fosforilação está relacionada a um efeito adipogênico com consequências para a sensibilidade à insulina. A estrutura do ligante GQ-16 ligado ao PPARy demonstra que o composto utiliza um modo de ligação distinto de outros ligantes de PPAR relatados, embora não partilham algumas características estruturais com outros agonistas parciais, tal como MRL-24. ${ }^{29}$ Estudos de hidrogênio / troca de deutério revelam que a GQ-16 estabiliza fortemente a região da folha- $\beta$ do receptor, presumivelmente explica a eficácia do composto na inibição da fosforilação mediada por Cdk5 de Ser273. Simulações de dinâmica molecular sugerem que a atividade de agonista parcial da GQ-16 resultam de fraca capacidade do composto para estabilizar a hélice 12 na sua conformação ativa. Estes estudos sugerem que o modelo emergente, em que a terapêutica à base de PPARy inibem a fosforilação mediada por Cdk5 é de fato um quadro válido para desenvolver melhores agonistas de PPARy que retêm as ações anti-diabéticos, minimizando os efeitos indesejáveis. ${ }^{83}$

O modo de ligação do complexo 3 faz com que ele não interaja com a H12 estabilizando as fitas- $\beta$ e provocando uma maior estabilização nesta região, assim como os ligantes GQ16 e MRL24, podendo ser um importante fármaco sensibilizador insulínico, sem causar diversos efeitos colaterais, já que o mesmo pode bloquear a fosforilação da Ser273 pela Cdk5. ${ }^{46}$ E este complexo pode ser classificado como um agonista parcial do PPARy. A análise do fator de temperatura da estrutura cristalográfica indica que a H12 é pouco estabilizada, isso mostra que a 
H12 pode ser muito dinâmica e capaz de adotar conformações ativas e inativas na presença do ligante.

Foram realizados ensaios de diferenciação de adipócitos do ligante 3 comparado com a rosiglitazona, onde pode-se ver que o ligante 3 apresenta efeitos adipogênicos reduzidos quando comparado a rosiglitazona. Com isso sugere-se que o complexo 3 pode ser um composto atrativo para o redesenho de novos fármacos que apresentem efeitos colaterais reduzidos.

Além dos ligantes citado acima o complexo 3 pode ser comparado com as amorfrutina 2 e amorfrutina $B$ que utilizam as moléculas de água para interagir com as fitas- $\beta$ e com a R288 da H3, assim como o complexo 3. As amorfrutinas são agonistas parciais independentes da $\mathrm{H} 12$ que tem alto potencial no tratamento da diabetes tipo $2 .^{125}$ 


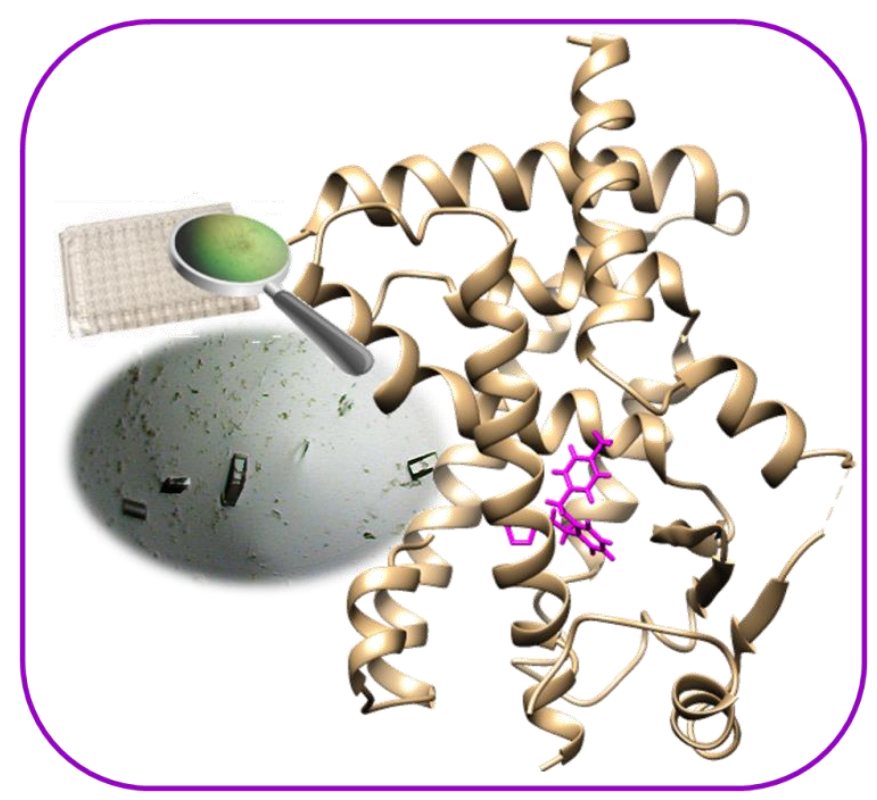

Capítulo 5

Resultados e Discussão

PPARY com o Ligante 4 


\section{PPARy com o Ligante 4}

\subsection{Cristalização e coleta de dados do PPARy com o Ligante 4}

Como já descrito na seção 3.5 diversas tentativas de cristalização foram realizadas utilizando citrato de sódio e Tris- $\mathrm{HCl}$ e HEPES em diversas concentrações, diferentes pHs e também kits de cristalização. Foram obtidos cristais do PPARy complexado com o ligante 4 pelo método de gota pendurada na condição contendo citrato de sódio 1,0 M, HEPES 0,1M pH 7,5. (Figura 26). Vários cristais foram submetidos à difração de raios-X na linha MX-2 do LNLS e foram obtidos conjunto de dados para o cristal do ligante 4 com o PPARy, porém com uma baixa resolução de $3 \AA ̊$, o que dificulta o mapa de densidade eletrônica em torno do ligante.

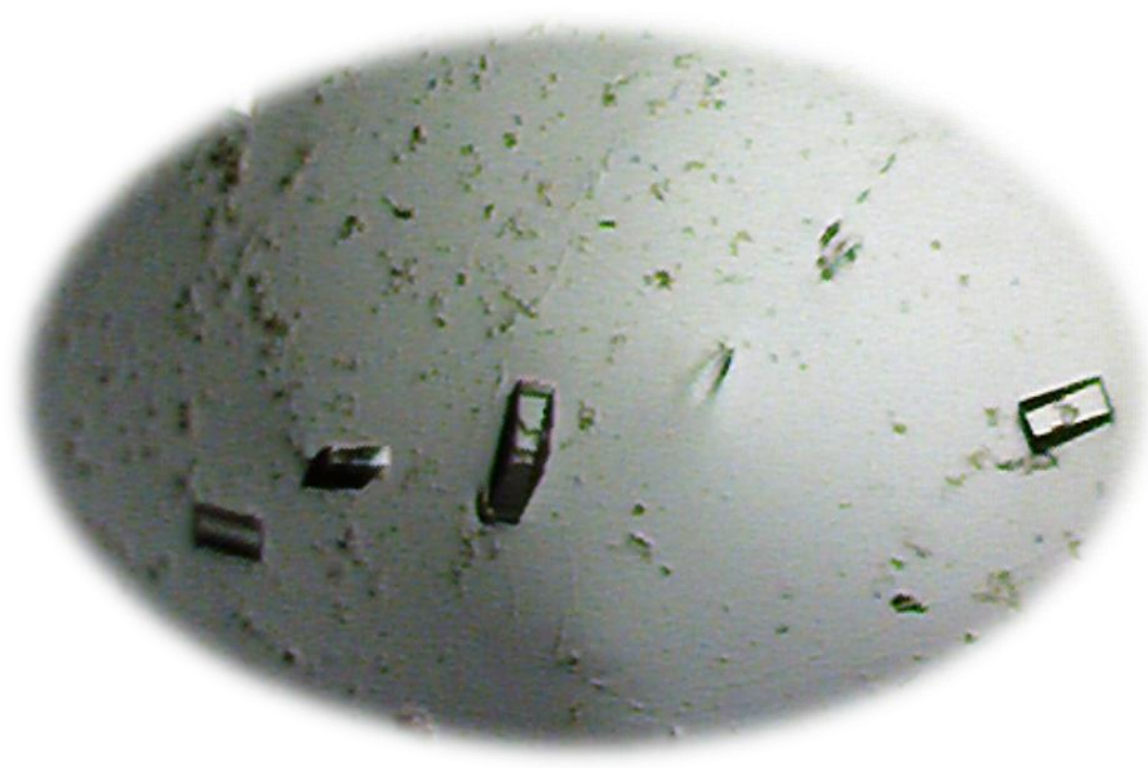

Figura 26 - Cristais obtidos do PPARy com o complexo 4.

Fonte: Elaborada pela autora

O complexo 4 assim como o complexo 3 apresenta em sua estrutura o grupo tetrazol, formado por um anel de quatro átomos de nitrogênio e um átomo de carbono. A estrutura tridimensional do complexo 4 com o PPARy foi resolvida no grupo espacial $\mathrm{C} 2$ e as estatísticas do processamento dos dados e refinamento da estrutura cristalográfica estão mostradas na tabela 2. Na unidade assimétrica foram observadas duas moléculas denominadas como cadeia A e cadeia B (Figura 27). 
Apenas na cadeia B foi identificada uma densidade característica do ligante 4, no qual o modo de ligação assim como para o complexo 3 mostrou-se dependente do estado conformacional da H12.

Tabela 2 - Estatísticas cristalográficas de coleta e refinamento do PPARy-LBD com o complexo 4.

\begin{tabular}{|c|c|}
\hline Parâmetros & PPARy-complexo 4 \\
\hline Comprimento de onda/Linha & 1,459/LNLS-MX2 \\
\hline Resolução $(\AA)$ & $45,6-3,0(3,107-3,0)$ \\
\hline Grupo espacial & $\mathrm{C} 2$ \\
\hline Cela unitária & $\begin{array}{c}92,8: 62,0 ; 118,2 \AA \\
\beta 101.84^{\circ}\end{array}$ \\
\hline Número de reflexões únicas & $13203(1342)$ \\
\hline Completeza (\%) & $98,45(98,82)$ \\
\hline$<\mathrm{I} / \sigma(\mathrm{I})\rangle$ & $8,18(0,92)$ \\
\hline B-factor médio & 60,26 \\
\hline R-factor / R-free & $0,2465(0,3794) / 0,3030(0,4217)$ \\
\hline Macromoléculas & 4034 \\
\hline Ligante & 22 \\
\hline Água & 0 \\
\hline Proteínas & 516 \\
\hline RMSD (ligação) Å & 0,026 \\
\hline RMSD (ângulo) ${ }^{\circ}$ & 0,96 \\
\hline Ramachandran plot (\%) & 0 \\
\hline Região favorável & 97 \\
\hline Região permitida & 0 \\
\hline Região não permitida & 0,79 \\
\hline Clashscore & 23,14 \\
\hline B-factor médio & 58,10 \\
\hline Macromoléculas & 58,10 \\
\hline Ligante & 51,90 \\
\hline
\end{tabular}

${ }^{*}$ Rmerge $=\sum \mathrm{hkl} \sum \mathrm{i}|\mathrm{l}(\mathrm{hkl})-</(\mathrm{hkl})>| l \sum \mathrm{hkl} \sum \mathrm{i}\langle/(\mathrm{hkl})>$, onde $\mathrm{li}(\mathrm{hkl})$ é a intensidade observada para $l(\mathrm{hkl})$ e $<l(\mathrm{hkl})>$ é a média das intensidades 

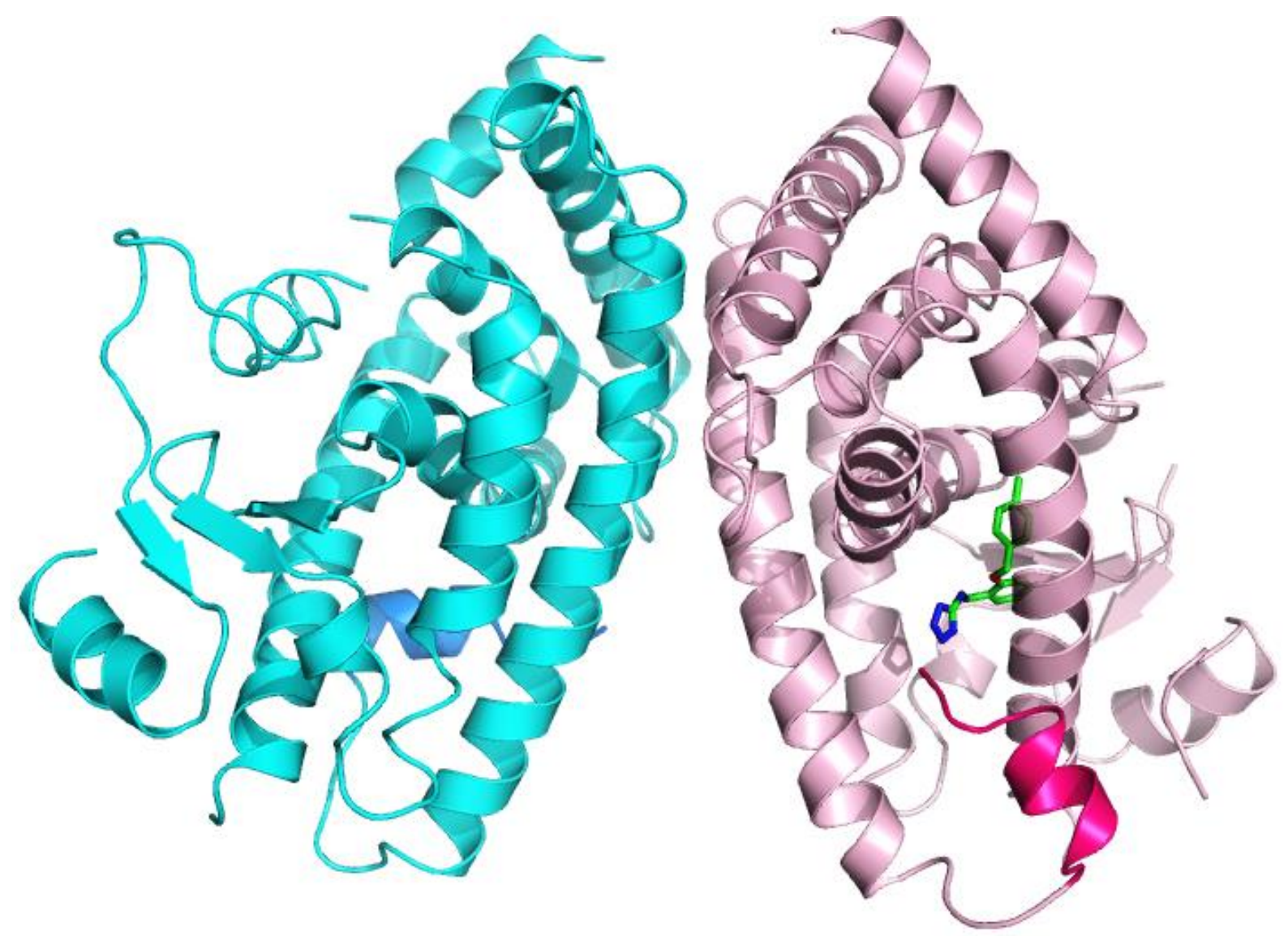

Figura 27 - Estrutura do PPARy com o complexo 4. A cadeia A está representada em ciano e a cadeia B em rosa, as H12 estão em destaque.

Fonte: Elaborada pela autora

A estrutura tridimensional do PPARy como complexo 4 consiste de $13 \alpha$ hélices formando um sanduíche de três camadas antiparalelas de a-hélices com 4 pequenas fitas- $\beta$, descritas anteriormente para estruturas de PPARy. ${ }^{75} \mathrm{O}$ conjunto foi refinado com valores de $R_{\text {factor }} 0,246$ e $R_{\text {free }} 0,303$, o refinamento foi dado como encerrado quando não foi mais possível a minimização desses índices. Como era de se esperar para o complexo 4 que possui em sua estrutura um anel tetrazol, a $\mathrm{H} 12$ da cadeia A está na conformação ativa e, portanto, encontra-se fechada sob o corpo do receptor. O complexo 4, mais especificamente o grupo tetrazol do ligante ocupa o braço I do PPARy, que é composto por resíduos polares e hidrofóbicos e, o braço II e III do receptor, respectivamente, são constituídos principalmente por resíduos hidrofóbicos. O complexo 4 ocupa o LBP do PPARy sem nenhuma interação com a Tyr473 da H12, como descrito para agonistas totais do PPARY.

$\mathrm{Na}$ cadeia $\mathrm{B}$ assim como para o complexo 3 , a $\mathrm{H} 12$ encontra-se na conformação inativa (aberta) e o anel tetrazol também está rotacionado para a 
direção da H3. Essa ocupação do ligante permite que ele faça interações hidrofóbicas com NH1 do anel tetrazol com a H449 com uma distância de 3,4 $\mathrm{A}$ e outra ligação de hidrogênio com o NH2 do anel tetrazol também com a H449 com uma distância de 3,2 Å. Outra ligação de hidrogênio presente na estrutura tridimensional entre o complexo 4 e o PPARy é entre a R288 e o grupo carboxila do complexo 4 com uma distância de $3,5 \AA$, esta é uma ligação de hidrogênio hidrofóbica e de van der Waals (Figura 28). Essas interações hidrofóbicas próximas às fitas- $\beta$ estão presentes em agonistas parciais do PPARY.

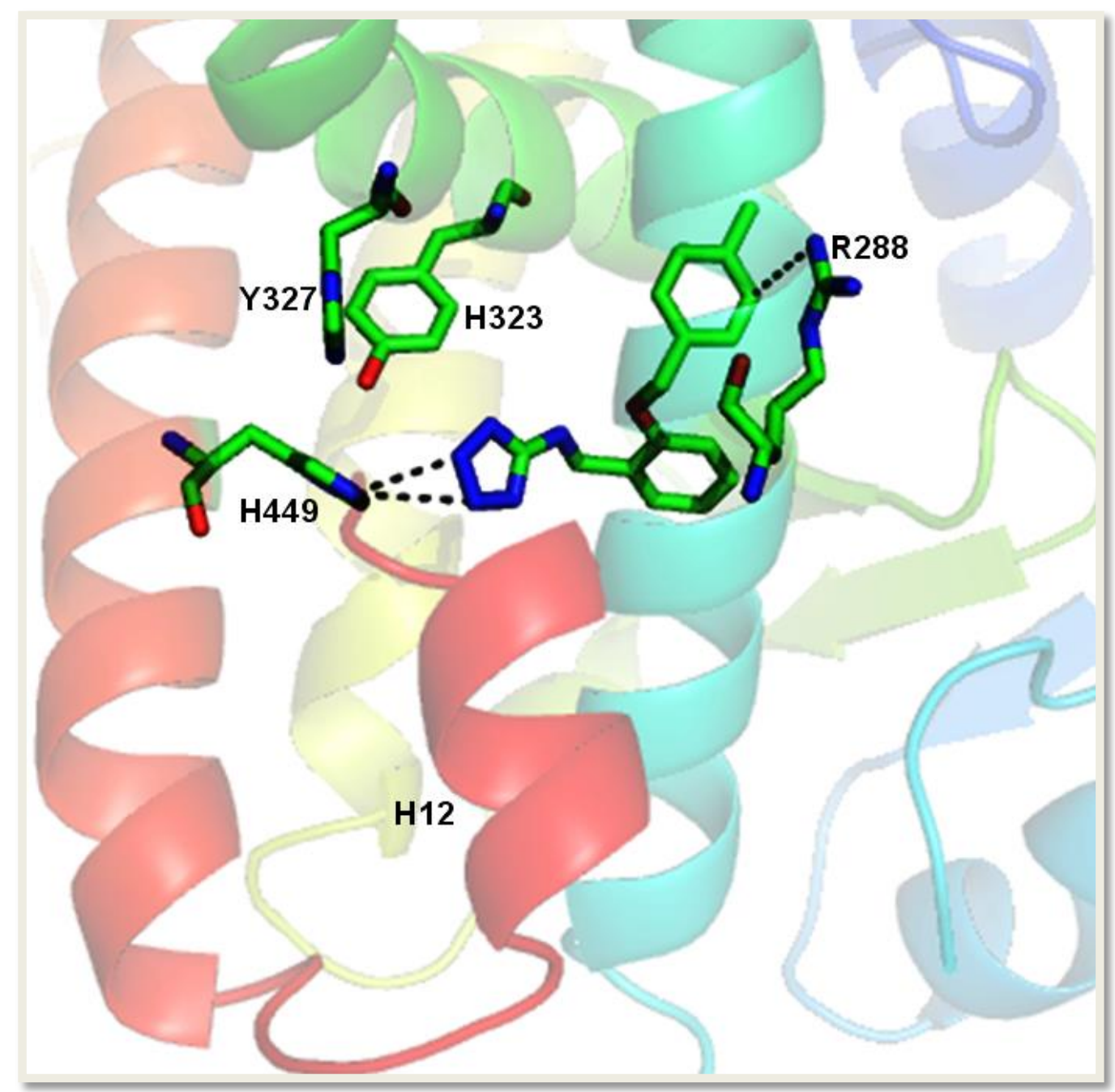

Figura 28 - Interações entre o ligante 4 e o receptor PPARY. As ligações de hidrogênio estão representadas em linhas tracejadas em preto.

Fonte: Elaborada pela autora

Como já foram mencionados anteriormente os agonistas totais como a rosiglitazona se ligam em uma conformação em forma de $U$ com a cabeça polar 
estendida na direção a hélice AF-2, assim formando uma ligação de hidrogênio com o grupo hidroxila da cadeia lateral da Y473, fazendo com que a $\mathrm{H} 12$ fique numa conformação fechada, porém ativa no qual os coativadores podem ativar e se ligar a maquinaria transcricional. ${ }^{125}$ Fazendo uma sobreposição com alguns agonistas parciais (Figura 29) como o MRL24, INT131, GQ16, amorfrutina I e amorfrutina II pode-se ver a similaridade entre elas e a acomodação dos ligantes no bolsão de ligação de forma semelhantes. Porém quando se observa o GQ16 que na Figura 30 está em amarelo ele está ligeiramente deslocado na região da fita- $\beta$, isso pode ser devido ao grupo espacial que é P212121.

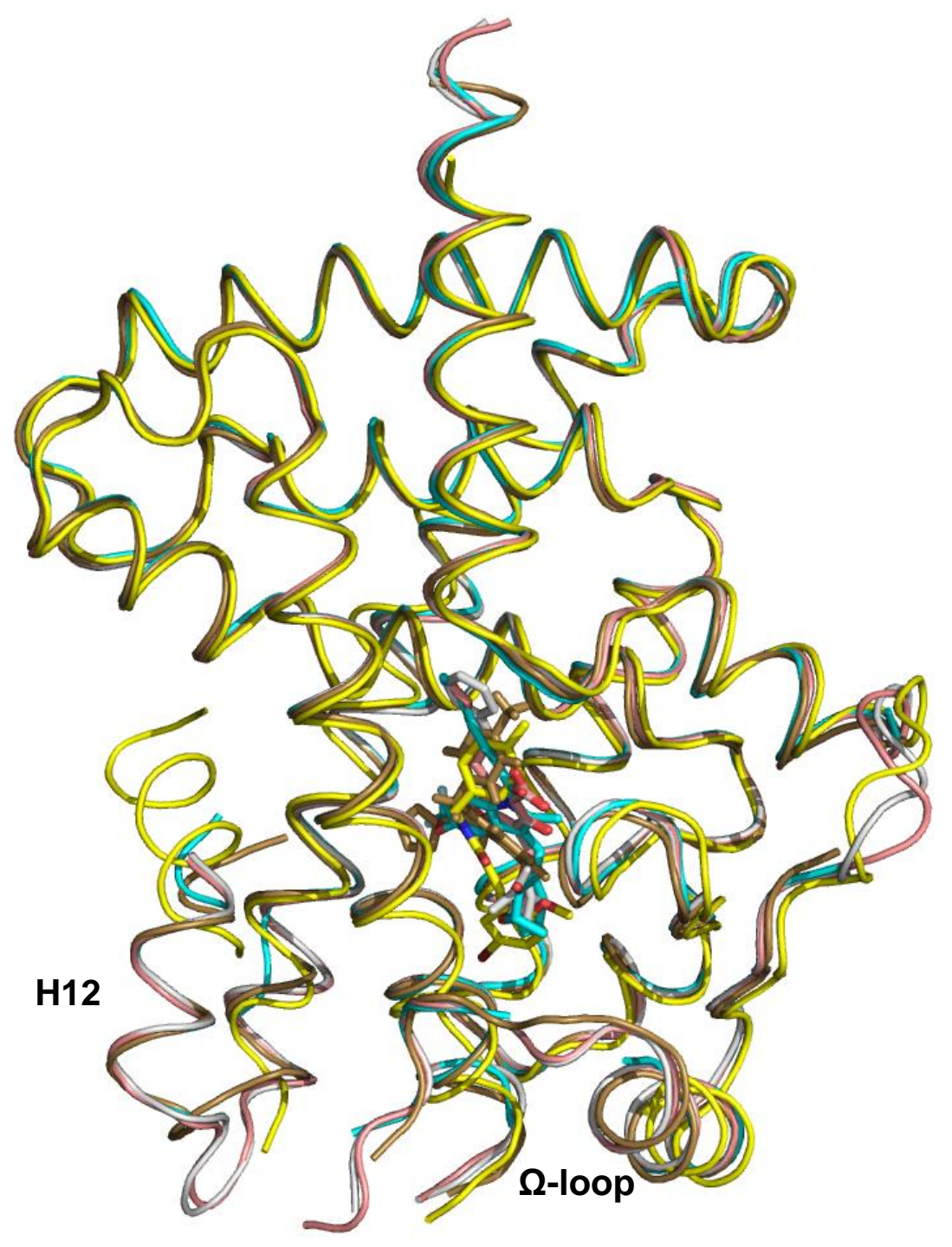

Figura 29 - Sobreposição do complexo 4 com o agonista total rosiglitazona. B. Sobreposição do complexo 4 com agonistas parciais MRL24 (PDB 2Q5P), INT131 (PDB 3FUR), GQ16 em amarelo (PDB 3T03), amorfrutina I (PDB 4A4V) e amorfrutina II (PDB 4A4W). 
No alinhamento do complexo 3 com o complexo 4 também nota-se a similaridade entre eles, porém 0 anel tetrazol dos ligantes estão rotacionados. $O$ anel tetrazol no complexo 3 está na posição meta e no complexo 4 este anel está na direção orto (Figura 30). Apesar de ainda nenhum estudo in vitro do complexo 4 tenha sido realizado essas evidências mostradas em relação ao complexo 4 e outros agonistas parciais do PPARy pode-se predizer que ele seja um agonista parcial do PPARY e que pode apresentar um efeito hipoglicemiante in vivo, via ativação do PPARY.

$\mathrm{Na}$ análise dos fatores de temperatura do complexo 4 (Figura 31) nota-se a mesma similaridade dos agonistas parciais e do complexo 3 , onde a região de maior estabilização é a região do $\Omega$-loop e fitas- $\beta$. Mais uma evidência que pode predizer que o complexo 4 faz parte da classe dos agonistas parciais do PPARY.

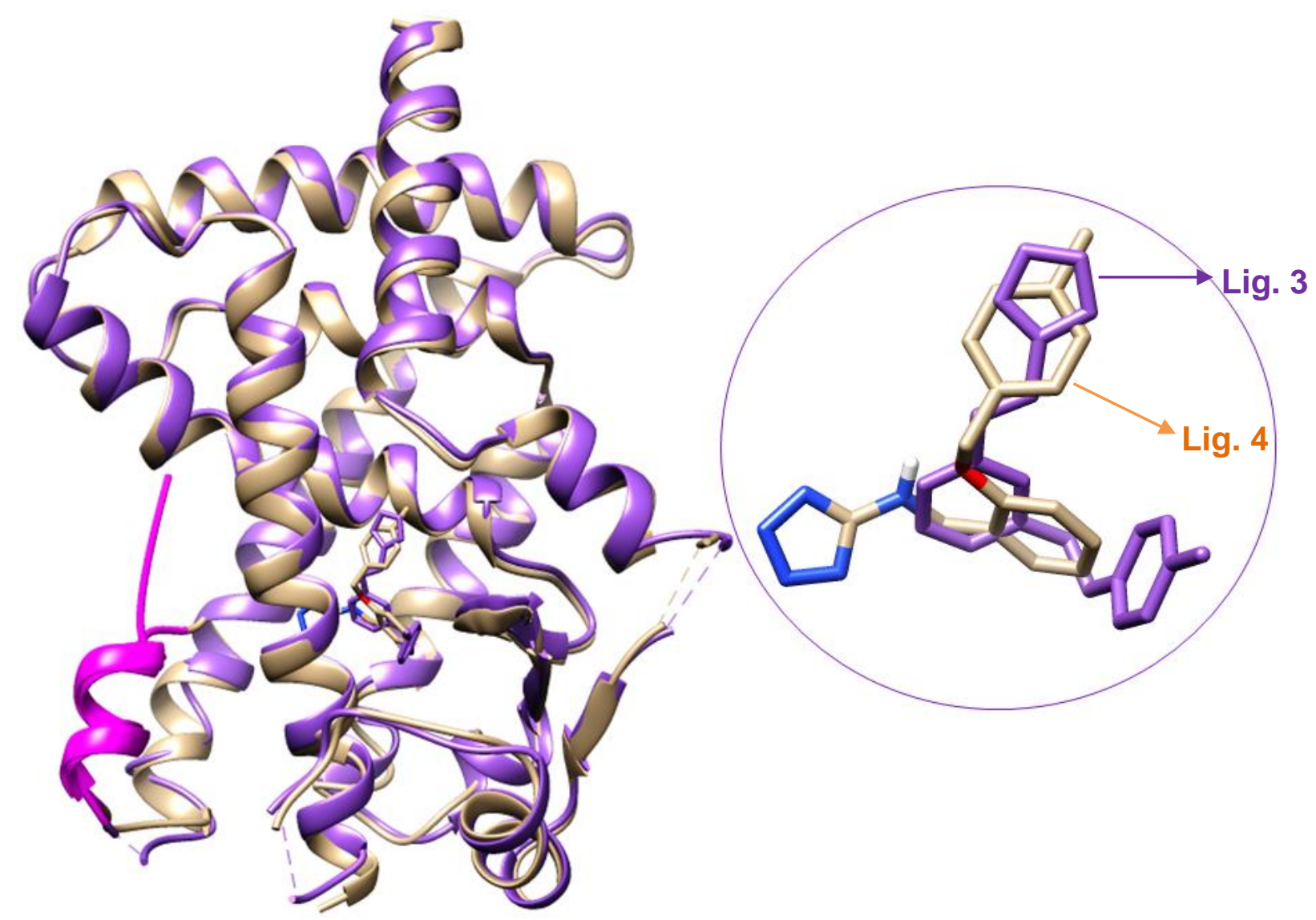

Figura 30 - Sobreposição do complexo 3 em lilás e do complexo 4 em dourado, em ambos a H12 está representada em rosa. Ao lado está em evidência a conformação dos ligantes. 

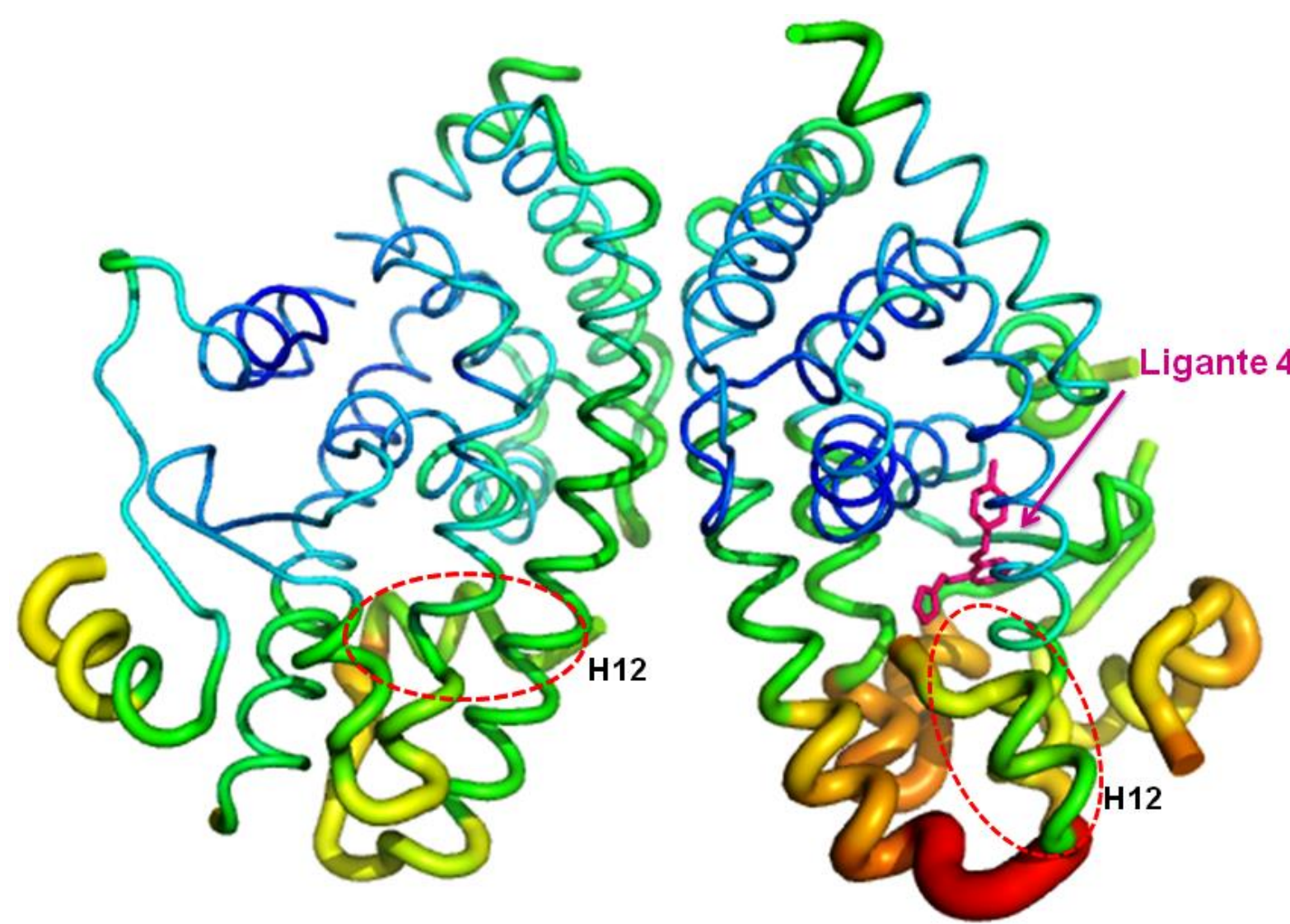

Figura 31 - Distribuição dos fatores de temperatura da cadeia A e da cadeia B do complexo 4. A H12 está representada em linhas tracejadas em vermelho.

Fonte: Elaborada pela autora

\subsubsection{Discussão}

Neste capítulo foi apresentado mais uma estrutura tridimensional do PPARY, complexado com o ligante 4. Os agonistas do PPARy são utilizados para o tratamento de diabetes tipo 2, aumentando a sensibilidade à insulina e diminuindo as adipocitocinas pró-inflamatórias. ${ }^{48}$ No entanto, os efeitos adversos, como a acumulação de água e o ganho leve, estão associados a alguns desses agonistas Estudos de expressão do PPARy em modelos murinos e humanos sugeriram que nem o agonismo total nem o antagonismo de PPARy oferecem uma abordagem de tratamento ideal para transtornos metabólicos. ${ }^{75}$ Ainda assim, a identificação de moléculas que ativam moderadamente o PPARy pode ser um importante objeto de estudo.

A análise estrutural do ligante 4 complexado com o PPARy fez com que ele fizesse importantes ligações de hidrogênio independente da $\mathrm{H} 12$ e estabilizando o 
$\Omega$-loop e fitas- $\beta$ através de interações hidrofóbicas entre a estrutura proteica e 0 ligante como vistas para agonistas parciais do PPARY. Além de que quando comparado os fatores de temperatura do complexo 4 com agonistas parciais o mesmo padrão de estabilização das hélices foram mantidos. Com isso pode-se predizer que o complexo 4 é um agonista parcial do PPARy. Dado que tanto o complexo 3 como o complexo 4 podem resultar em menos efeitos adversos em comparação com os ativadores totais do PPARY como a rosiglitazona, mantendo os efeitos metabólicos benéficos associados à ativação moderada de PPARY.

Estes dois ligantes apresentam na sua estrutura o grupo tetrazol, e podem ser considerados agonistas parciais importantes, pois em uma Patente que foi publicada em $1989,{ }^{135}$ (Figura 32) mostrou que a partir dos dados experimentais obtidos, é evidente que os compostos que apresentam esta estrutura reduzem os níveis de glicose no sangue, o que os caracteriza como agentes anti-hiperglicêmicos úteis no tratamento de estados patológicos que envolvem níveis sanguíneos anormalmente elevados de glicose, como diabetes mellitus. Também demonstrou que os ratos tratados com compostos tetrazóis similares, tiveram uma redução da glicemia em função do tempo, mostrando que estes dados corroboram com dados em células $E$. coli e corroboram com dados in vivo que dizem que ele é ativo. Possuem efeito PPARY dependente e esses ligantes são considerados agonistas parciais pelo modo de ligação que eles apresentam com o PPARy. ${ }^{135}$

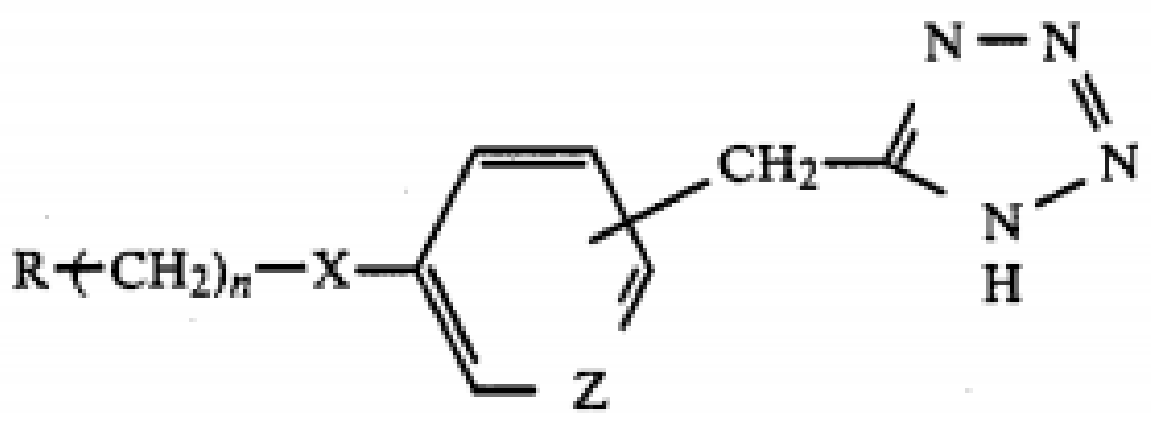

Figura 32 - Estrutura química de compostos tetrazóis publicado na patente por Kenneth e colaboradores.

Fonte: Adaptado de Kenneth ${ }^{135}$ 


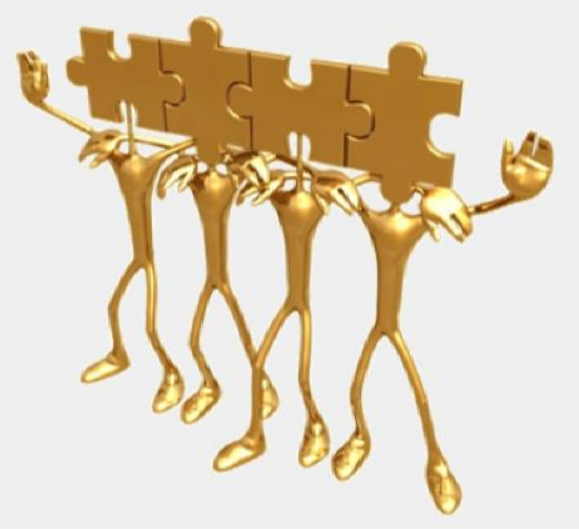

Capítulo 6

Considerações

Finais 


\section{CONSIDERAÇÕES FINAIS}

Com diversos efeitos colaterais relacionados aos TZDs, novos grupos funcionais que levem a uma diminuição desses efeitos colaterais pode ser uma alternativa para o tratamento do diabetes tipo II. Este conjunto de informações estruturais apresentados neste trabalho para o PPARy foi de grande valia para o entendimento das interações que esse receptor é capaz de fazer na presença de um ligante, além de que alguns destes complexos apresentados neste trabalho possuem características únicas que poderão ser útil no desenvolvimento de novos moduladores seletivos do PPARY semelhante ao que já se encontram no mercado porém com efeitos colaterais reduzidos.

O mecanismo de ativação clássico propõe que os ligantes ativem os RNs estabilizando a $\mathrm{H} 12$ em uma posição favorável para alojar moléculas coativadoras. Esse mecanismo é consistente com a observação de que os agonistas totais do PPARy tipicamente ativam a região da função de ativação-2 (AF-2), interagindo com a $\mathrm{H} 12$ por meio de uma ligação de hidrogênio com Tyr473. No entanto, estudos com agonistas parciais mostraram que tais ligantes não interagem diretamente com $\mathrm{H} 12$, sua atividade transcricional não está correlacionada exclusivamente com mudanças estruturais ou dinâmicas na H12. Portanto, outras regiões da LBD podem desempenhar papéis na ativação induzida pelo ligante, como o $\Omega$-loop, que parece ser particularmente importante para a ativação de PPARy. Um aspecto que ainda não é claro é se o $\Omega$-loop funciona através de um mecanismo alostérico envolvendo a $\mathrm{H} 12$.

Nesse panorama este trabalho apresentou estudos estruturais de dois complexos denominados 3 e 4 com o PPARy com características únicas, no qual pode-se dizer que estes complexos são classificados como agonistas parciais do PPARy pois na análise de suas interações foi possível ver que nenhum dos ligantes interagiam com a $\mathrm{H} 12$ através de ligações de hidrogênio. Estes ligantes apresentam o grupo tetrazol na sua estrutura, um grupo funcional que ainda é pouco comum em relação aos ligantes encontrados para o PPARy. Além de que para o complexo 3 no teste de diferenciação de adipócitos mostrou que o ligante 3 possui em efeito adipogênico reduzido quando comparado a rosiglitazona, e provavelmente não promovendo o ganho de peso assim como os agonistas totais. Portanto, esses complexos podem ter o potencial de melhora no controle da 
resistência à insulina, e ser possíveis candidatos a fármacos para o tratamento de diabetes tipo II. Esses resultados nos proporcionaram um melhor entendimento de como agonistas parciais interagem com o PPARy através de suas ligações de hidrogênio e esses agonistas podem representar novos moldes para o desenho de novos fármacos relacionados ao PPARY. 


\section{Referências}

1 AMBER-VITOS, O. et al. The effect of regulating molecules on the structure of the PPARRXR complex. Biochimica et Biophysica Acta - molecular and cell biology of lipids, $v$. 1861, n. 11, p. 1852-1863, Nov. 2016.

2 ARANDA, A.; PASCUAL, A. Nuclear hormone receptors and gene expression. Physiological Reviews, v. 81, n. 3, p. 1269-1304, July 2001.

3 BOGAN, A. A.; COHEN, F. E.; SCANLAN, T. S. Natural ligands of nuclear receptors have conserved volumes. Nature Structural \& Molecular Biology, v. 5, n. 8, p. 679-681, Aug. 1998.

4 BOURGUET, W.; GERMAIN, P.; GRONEMEYER, H. Nuclear receptor ligand-binding domains: three-dimensional structures, molecular interactions and pharmacological implications. Trends in Pharmacological Sciences, v. 21, n. 10, p. 381-388, Oct. 2000.

5 COLLE, R. et al. PPAR-gamma Agonists for the treatment of major depression: a review. Pharmacopsychiatry, v. 50, n. 2, p. 49-55, Mar. 2017.

6 FARCE, A.; RENAULT, N.; CHAVATTE, P. Structural Insight into PPAR gamma Ligands Binding. Current Medicinal Chemistry, v. 16, n. 14, p. 1768-1789, May 2009.

7 GRONEMEYER, H.; GUSTAFSSON, J. A.; LAUDET, V. Principles for modulation of the nuclear receptor superfamily. Nature Reviews Drug Discovery, v. 3, n. 11, p. 950-964, Nov. 2004.

$8 \mathrm{KOO}, \mathrm{J} . \mathrm{B}$. et al. Anti-fibrogenic effect of PPAR-gamma agonists in human intestinal myofibroblasts. BMC Gastroenterology, v. 17, n. 1, p. 73, June 072017.

9 MORAS, D. et al. Structure-function relationships in nuclear receptors: the facts. Trends Biochemistry Science, v. 40, n. 6, p. 287-290, June 2015.

10 NASCIMENTO, A. S. et al. Structural rearrangements in the thyroid hormone receptor hinge domain and their putative role in the receptor function. Journal of Molecular Biology, v. 360, n. 3, p. 586-598, July 142006.

11 TANENBAUM, D. $M$. et al. Crystallographic comparison of the estrogen and progesterone receptor's ligand binding domains. Proceedings of the National Academy of Sciences of the United States of America, v. 95, n. 11, p. 5998-6003, May 1998.

12 BRUNING, J. B. et al. Partial agonists activate PPARgamma using a helix 12 independent mechanism. Structure, v. 15, n. 10, p. 1258-1271, Oct. 2007.

13 LIMEI, W. et al. Natural product agonists of peroxisome proliferator-activated receptor gamma (PPARy): a review. Biochemical Pharmacology, v. 92, n. 1, p. 73-89, 2014.

14 MASAO, O. et al. Different structures of the two peroxisome proliferator-activated receptor gamma (PPARy) ligand-binding domains in homodimeric complex with partial agonist, but not full agonist. Bioorganic \& Medicinal Chemistry Letters, v. 25, n. 13, p. 2639-2644, 2015.

15 HARMON, G. S.; LAM, M. T.; GLASS, C. K. PPARs and lipid ligands in inflammation and metabolism. Chemistry Review, v. 111, p. 6321-6340, 2011. 
16 SCHULMAN, I. G. Nuclear receptors as drug targets for metabolic disease. Advanced Drug Delivery Reviews, v. 62, n. 13, p. 1307-1315, Oct. 2010.

17 RENAULD, J. P. et al. Crystal structure of the RAR-gamma ligand-binding domain bound to all-trans retinoic acid. Nature, v. 378, n. 6558, p. 681-689, 1995.

$18 \mathrm{XU}, \mathrm{H}$. E. et al. Molecular recognition of fatty acids by peroxissome proliferator-activated receptors. Molecular Cell, v. 3, n. 3, p. 397-403, Mar. 1999.

19 LU, I.-L. et al. Structure-based drug design of a novel family of PPARy partial agonists: virtual screening, X-ray crystallography, and in vitro/in vivo biological activities. Journal of Medicinal Chemistry, v. 49, n. 9, p. 2703-2712, 4 May 2006.

20 ZOETE, V.; GROSDIDIER, A.; MICHIELIN, O. Peroxisome proliferator-activated receptor structures: Ligand specificity, molecular switch and interactions with regulators. Biochimica et Biophysica Acta (BBA) - molecular and cell biology of lipids, v. 1771, n. 8, p. 915-925, Aug. 2007.

21 BURNS, K.; VANDENHEUVEL, J. Modulation of PPAR activity via phosphorylation. Biochimica et Biophysica Acta (BBA) - molecular and cell biology of lipids, v. 1771, n. 8, p. 952-960, Aug. 2007.

22 ISSEMANN, I.; GREEN, S. Activation of a member of the steroid hormone receptor superfamily by peroxisome proliferators. Nature, v. 347, n. 6294, p. 645-650, 18 Oct. 1990.

23 BERGER, J.; MOLLER, D. E. The mechanisms of action of PPARs. Annual Review of Medicine, v. 53, p. 409-435, 2002.

24 TRAVIS, S. et. al. An alternate binding site for PPARy ligands. Nature Communications, v. 5, n. 3571, 2014. doi: 10.1038/ncomms4571.

25 LALLOYER, F.; STAELS, B. Fibrates, glitazones, and peroxisome proliferator-activated receptors. Arteriosclerosis, Thrombosis, and Vascular Biology, v. 30, n. 5, p. 894-899, May 2010.

26 DREYER, C. et al. Positive regulation of the peroxisomal beta-oxidation pathway by fatty acids through activation of peroxisome proliferator-activated receptors (PPAR). Biology of the Cell, v. 77, n. 1, p. 67-76, 1993.

27 DREYER, C. et al. Control of the peroxisomal beta-oxidation pathway by a novel family of nuclear hormone receptors. Cell, v. 68, n. 5, p. 879-87, 6 Mar. 1992.

28 NIELSEN, R. et al. Peroxisome proliferator-activated receptor subtype- and cell-typespecific activation of genomic target genes upon adenoviral transgene delivery. Molecular and Cellular Biology, v. 26, n. 15, p. 5698-714, Aug. 2006.

29 EVANS, R. M.; BARISH, G. D.; WANG, Y.-X. PPARs and the complex journey to obesity. Nature Medicine, v. 10, n. 4, p. 355-361, 31 Mar. 2004.

30 GEARING, K. L. et al. Interaction of the peroxisome-proliferator-activated receptor and retinoid $X$ receptor. Proceedings of the National Academy of Sciences of the United States of America, v. 90, n. 4, p. 1440-4, 15 Feb. 1993. 
31 LEMBERGER, T.; DESVERGNE, B.; WAHLI, W. Peroxisome proliferator-activated receptors: a nuclear receptor signaling pathway in lipid physiology. Annual Review of Cell and Developmental Biology, v. 12, n. 1, p. 335-363, Nov. 1996.

32 YU, S.; REDDY, J. Transcription coactivators for peroxisome proliferator-activated receptors. Biochimica et Biophysica Acta (BBA) - molecular and cell biology of lipids, v. 1771, n. 8, p. 936-951, Aug. 2007.

33 RÔ, J.; FEIGE, N.; AUWERX, J. Transcriptional coregulators in the control of energy homeostasis. Trends in Cell Biology, v. 17, n. 6, p. 292-301, June 2007.

34 WANG, L. et al. Natural product agonists of peroxisome proliferator-activated receptor gamma (PPARy): a review. Biochemical pharmacology, v. 92, n. 1, p. 73-89, 1 Nov. 2014.

35 CHANDRA, V. et al. Structure of the intact PPAR-gamma-RXR- nuclear receptor complex on DNA. Nature, v. 456, n. 7220, p. 350-6, 20 Nov. 2008.

36 GAWRYSZEWSKA, P. et al. Synthesis, characterization and role in biotechnology: ligand interactions in nuclear receptors. New York: New Science Publishers, 2014. cap. 1, p. 1-37.

37 PETERS, J. M.; SHAH, Y. M.; GONZALEZ, F. J. The role of peroxisome proliferatoractivated receptors in carcinogenesis and chemoprevention. Nature Reviews Cancer, v. 12, n. 3, p. 181-195, 2012.

38 TANAKA, T. et al. Activation of peroxisome proliferator-activated receptor induces fatty acid -oxidation in skeletal muscle and attenuates metabolic syndrome. Proceedings of the National Academy of Sciences, v. 100, n. 26, p. 15924-15929, 23 Dec. 2003.

39 WANG, Y.-X. et al. Regulation of muscle fiber type and running endurance by PPARס. PLoS Biology, v. 2, n. 10, p. e294, Aug. 2004.

40 WANG, Y.-X. et al. Peroxisome-proliferator-activated receptor delta activates fat metabolism to prevent obesity. Cell, v. 113, n. 2, p. 159-70, Apr. 2003.

$41 \mathrm{LIU}, \mathrm{S}$. et al. Role of peroxisome proliferator-activated receptor $\delta / \beta$ in hepatic metabolic regulation. Journal of Biological Chemistry, v. 286, n. 2, p. 1237-1247, Jan. 2011.

42 OLIVER, W. R. et al. A selective peroxisome proliferator-activated receptor agonist promotes reverse cholesterol transport. Proceedings of the National Academy of Sciences, v. 98, n. 9, p. 5306-5311, 24 Apr. 2001.

43 SPRECHER, D. L. et al. Triglyceride:high-density lipoprotein cholesterol effects in healthy subjects administered a peroxisome proliferator activated receptor $\delta$ agonist. Arteriosclerosis, Thrombosis, and Vascular Biology, v. 27, n. 2, 2007. doi: 10.1155/2008/132960.

44 UHLEN, $M$. et al. Towards a knowledge-based human protein atlas. Nature Biotechnology, v. 28, n. 12, p. 1248-1250, Dec. 2010.

45 MONSALVE, F. A et al. Peroxisome proliferator-activated receptor targets for the treatment of metabolic diseases. Mediators of Inflammation, v. 2013, p. 549627, 2013. doi: $10.1155 / 2013 / 549627$. 
46 MORAS, D.; GRONEMEYER, H. The nuclear receptor ligand-binding domain: structure and function. Current Opinion in Cell Biology, v. 10, n. 3, p. 384-391, June 1998.

47 RICOTE, M.; VALLEDOR, A. F.; GLASS, C. K. Decoding transcriptional programs regulated by PPARs and LXRs in the macrophage: effects on lipid homeostasis, inflammation, and atherosclerosis. Arteriosclerosis, Thrombosis, and Vascular Biology, v. 24, n. 2, p. 230-239, Feb. 2004.

48 GUAN, Y. Targeting peroxisome proliferator-activated receptors (PPARs) in kidney and urologic disease. Minerva Urologica e Nefrologica $=$ the italian journal of urology and nephrology, v. 54, n. 2, p. 65-79, June. 2002.

49 SCOTT, C. L. Diagnosis, prevention, and intervention for the metabolic syndrome. American Journal of cardiology, v. 92, n. 1A, p. 35i-42i, 3 July 2003.

50 KOTA, B. P.; HUANG, T. H.; ROUFOGALIS, B. D. An overview on biological mechanisms of PPARs. Pharmacological Research, v. 51, n. 2, p. 85-94, 2005.

51 WILLSON, T. M. et al. The PPARs: from orphan receptors to drug discovery. Journal of Medicinal Chemistry, v. 43, n. 4, p. 527-550, 2000.

52 FAJAS, L. F.; FRUCHART, J. C.; AUWERX, J. PPARgamma3 mRNA: a distinct PPARgamma mRNA subtype transcribed from an independent promoter. FEBS Letters, v. 438, n.1, p. 55-60, 1998.

53 JIANG, C.; TING, A. T.; SEED, B. PPAR-gamma agonists inhibit production of monocyte inflammatory cytokines. Nature, v. 391, n. 6662, p. 82-86, Jan. 1998.

54 GUERRE, M. et. al. Peroxisome proliferator-activated receptor alpha activators improve insulin sensitivity and reduce adiposity. Journal Biological Chemical, v. 275, n. 22, p. 16638-16642, June 2000.

$55 \mathrm{CHOI}, \mathrm{J}$. H. et al. Anti-diabetic drugs inhibit obesity-linked phosphorylation of PPARy by Cdk5. Nature, v. 466, n. 7305, p. 451-456, July 2010.

56 RANGWALA, S. M. et al. Genetic modulation of PPARgamma phosphorylation regulates insulin sensitivity. Developmental Cell, v. 5, n. 4, p. 657-63, Oct. 2003.

57 SINGH, M. P. et. al Peroxisome proliferator-activated receptors (PPARs). A target with a broad therapeutic potencial for human diseases: an overview. Pharmacologyonline, v. 2, p. 58-89, 2001.

58 LECARPENTIER, Y. et al. Interactions between PPAR gamma and the canonical Wnt/Beta-Catenin Pathway in Type 2 diabetes and colon cancer. PPAR Research, v. 2017, p. 1-9, Feb. 2017.

59 MICHALIK, L. et al. International union of pharmacology. LXI. peroxisome proliferatoractivated receptors. Pharmacological Reviews, v. 58, n. 4, p. 726-741, Dec. 2006.

60 ROTMAN, N.; WAHLI, W. Fatty acid synthesis and PPARa hand in hand. Chemistry \& Biology, v. 16, n. 8, p. 801-802, 28 Aug. 2009. 
61 WOLFRUM, C. et al. Fatty acids and hypolipidemic drugs regulate peroxisome proliferator-activated receptors - and -mediated gene expression via liver fatty acid binding protein: a signaling path to the nucleus. Proceedings of the National Academy of Sciences, v. 98, n. 5, p. 2323-2328, Feb. 2001.

62 MALTAROLLO, V. G. et al. Structure-based virtual screening and discovery of new PPAR $\delta / y$ dual agonist and PPAR $\delta$ and $y$ agonists. PLOS ONE, v. 10, n. 3, p. e0118790, Mar. 2015.

63 ROBINSON, E.; GRIEVE, D. J. Significance of peroxisome proliferator-activated receptors in the cardiovascular system in health and disease. Pharmacology \& Therapeutics, v. 122, n. 3, p. 246-263, June 2009.

64 WANG, Y. et al. The intestinal bioavailability of vaccenic acid and activation of peroxisome proliferator-activated receptor- $\alpha$ and $-\gamma$ in a rodent model of dyslipidemia and the metabolic syndrome. Molecular Nutrition \& Food Research, v. 56, n. 8, p. 1234-1246, Aug. 2012.

65 GARCIA, A. C. et al. Discovery of a Series of Imidazo[4,5-b]pyridines with dual activity at angiotensin II type 1 receptor and peroxisome proliferator-activated receptor- $\gamma$. Journal of Medicinal Chemistry, v. 54, n. 12, p. 4219-4233, May 2011.

66 BUSS, Z. S.; MEDEIROS, Y. S.; FRÖDE, T. S. PPAR-gamma agonist rosiglitazone attenuates the inflammation caused by carrageenan in the mouse model of pleurisy. Inflammation, v. 35, n. 1, p. 280-288, 5 Feb. 2012.

$67 \mathrm{YU}, \mathrm{Y}$. et al. Peroxisome proliferator-activated receptor- regulates inflammation and renin-angiotensin system activity in the hypothalamic paraventricular nucleus and ameliorates peripheral manifestations of heart failure. Hypertension, v. 59, n. 2, p. 477-484, Feb. 2012.

68 CHEN, Y. C. et al. Peroxisome proliferator-activated receptor gamma (PPAR-Y) and neurodegenerative disorders. Molecular Neurobiology, v. 46, n. 1, p. 114-124, Aug. 2012.

69 BOLDEN, A. et al. The PPAR gamma agonist troglitazone regulates Erk 1/2 phosphorylation via a PPARy-independent, MEK-dependent pathway in human prostate cancer cells. PPAR Research, v. 2012, p. 1-9, Feb. 2012.

70 ROBBINS, G. T.; NIE, D. PPAR gamma, bioactive lipids, and cancer progression. Frontiers in Bioscience, v. 17, p. 1816-34, Jan. 2012.

71 ROGENHOFER, S. et al. Enhanced expression of peroxisome proliferate-activated receptor gamma (PPAR- $\gamma$ ) in advanced prostate cancer. Anticancer Research, v. 32, n. 8, p. 3479-83, Aug. 2012.

72 RAJAPAKSHA, $\mathrm{H}$. et al. X-ray crystal structure of rivoglitazone bound to PPARy and PPAR subtype selectivity of TZDs. Biochimica et Biophysica Acta - general subjects, v. 1861, n. 8, p. 1981-1991, 2017.

73 FRKIC, R. L. et al. Structure-activity relationship of 2,4-Dichloro- $N$-(3,5-dichloro-4(quinolin-3-yloxy)phenyl)benzenesulfonamide (INT131) analogs for PPARy-targeted antidiabetics. Journal of Medicinal Chemistry, v. 60, n. 11, p. 4584-4593, June 2017. 
74 BAILEY, C. J. The rise and fall of troglitazone. Diabetic Medicine, v. 17, p. 414-415, 2000.

75 BRUNING, J. B. et al. Partial agonists activate PPARy using a helix 12 independent mechanism. Structure, v. 15, n. 10, p. 1258-1271, Oct. 2007.

76 TONTONOZ, P. et al. mPPAR gamma 2: tissue-specific regulator of an adipocyte enhancer. Genes \& Development, v. 8, n. 10, p. 1224-34, May 1994.

77 KERSTEN, S. Mechanisms of nutritional and hormonal regulation of lipogenesis. EMBO Reports, v. 2, n. 4, p. 282-286, Apr. 2001.

78 PIRAT, C. et al. Targeting peroxisome proliferator-activated receptors (PPARs): development of modulators. Journal of Medicinal Chemistry, v. 55, n. 9, p. 4027-4061, May 2012.

79 CAPELLI, D. et al. Structural basis for PPAR partial or full activation revealed by a novel ligand binding mode. Scientific Reports, v. 6, n. 34792, Oct. 2016. doi:10.1038/srep34792.

80 KROKER, A. J.; BRUNING, J. B. Review of the structural and dynamic mechanisms of PPARy partial agonism. PPAR Research, v. 2015, p. 816856, 2015. doi: $10.1155 / 2015 / 816856$.

81 ACTON, J. J. et al. Benzoyl 2-methyl indoles as selective PPAR gamma modulators. Biooganic \& Medicinal Chemistry Letters, v. 15, n. 2, p. 357-362, 2005.

82 FRIEDLAND, S. N. et. al. The cardiovascular effects of peroxisome proliferator-activated receptor agonists. American Journal Medicine, v. 125, n. 2, p. 126-133. Feb. 2012.

83 AMATTO, A. A. et al. GQ-16, a novel peroxisome proliferator-activated receptor $Y$ (PPARY) ligand, promotes insulin sensitization without weight gain. Journal of Biological Chemistry, v. 287, n. 33, p. 28169-28179, 2012. doi: 10.1074/jbc.M111.332106.

84 CARIOU, B.; CHARBONNEL, B. STAELS, B. Thiazolidinediones and PPARgamma agonists: time for a reassessment. Trends in Endocrinology \& Metabolism, v. 23, n. 5, p. 205-215, 2012.

85 IVANOVA, E. A. et al. Peroxisome proliferator-activated receptor (PPAR) gamma in cardiovascular disorders and cardiovascular surgery. Journal of Cardiology, v. 66, n. 4, p. 271-278, Oct. 2015.

86 WILDING, J. P. H. PPAR agonists for the treatment of cardiovascular disease in patients with diabetes. Diabetes, Obesity and Metabolism, v. 14, n. 11, p. 973-982, Nov. 2012.

$87 \mathrm{KAHN}, \mathrm{S}$. E. et al. Glycemic durability of rosiglitazone, metformin, or glyburide monotherapy. New England Journal of Medicine, v. 355, n. 23, p. 2427-2443, 7 Dec. 2006.

88 SPIEGELMAN, B. M. PPAR-gamma: adipogenic regulator and thiazolidinedione receptor. Diabetes, v. 47, n. 4, p. 507-14, Apr. 1998.

89 CIPOLLETTA, D. et al. PPAR-y is a major driver of the accumulation and phenotype of adipose tissue Treg cells. Nature, v. 486, n. 7404, p. 549-553, 16 May 2012. 
90 CHANG, C.-S. et al. Diuretics prevent thiazolidinedione-induced cardiac hypertrophy without compromising insulin-sensitizing effects in mice. American Journal of Pathology, v. 184, n. 2, p. 442-453, Feb. 2014.

91 DUAN, S. Z. et al. Cardiomyocyte-specific knockout and agonist of peroxisome proliferator-activated receptor- both induce cardiac hypertrophy in mice. Circulation Research, v. 97, n. 4, p. 372-379, 28 July 2005.

92 FESTUCCIA, W. T. et al. Rosiglitazone-induced heart remodelling is associated with enhanced turnover of myofibrillar protein and mTOR activation. Journal of Molecular and Cellular Cardiology, v. 47, n. 1, p. 85-95, July 2009.

$93 \mathrm{MANNUCCI}$, E. et al. Cardiac safety profile of rosiglitazone. International Journal of Cardiology, v. 143, n. 2, p. 135-140, Aug. 2010.

94 ASAKAWA, M. et al. Peroxisome proliferator-activated receptor gamma plays a critical role in inhibition of cardiac hypertrophy in vitro and in vivo. Circulation, v. 105, n. 10, p. 1240-6, 12 Mar. 2002.

95 BALAS, B. et al. Pioglitazone treatment increases whole body fat but not total body water in patients with non-alcoholic steatohepatitis. Journal of Hepatology, v. 47, n. 4, p. 565570, Oct. 2007.

96 KRISHNASWAMI, A.; RAVI-KUMAR, S.; LEWIS, J. M. Thiazolidinediones: a 2010 perspective. Permanente Journal, v. 14, n. 3, p. 64-72, 2010.

97 HSUEH, W. A.; LAW, R. E. PPARgamma and atherosclerosis: effects on cell growth and movement. Arteriosclerosis, Thrombosis, and Vascular Biology, v. 21, n. 12, p. 18911895, Dec. 2001.

98 OREKHOV, A. N. et al. Macrophages in immunopathology of atherosclerosis: a target for diagnostics and therapy. Current Pharmaceutical Design, v. 21, n. 9, p. 1172-1179, 2015.

99 DUAN, S. Z.; USHER, M. G.; MORTENSEN, R. M. PPARs: the vasculature, inflammation and hypertension. Current Opinion in Nephrology and Hypertension, v. 18, n. 2, p. 128133, Mar. 2009.

100 SEED, B.; JIANG, C.; TING, A. T. PPAR-gamma agonists inhibit production of monocyte inflammatory cytokines. Nature, v. 391, n. 6662, p. 82-86, Jan. 1998.

101 BERRY, A. et al. IL-13 induces expression of CD36 in human monocytes through PPARY activation. European Journal of Immunology, v. 37, n. 6, p. 1642-1652, June 2007.

102 SUGAWARA, A. et al. Transcriptional suppression of type 1 angiotensin II receptor gene expression by peroxisome proliferator-activated receptor- $y$ in vascular smooth muscle cells. Endocrinology, v. 142, n. 7, p. 3125-3134, July 2001.

103 BENKIRANE, K. et al. Peroxisome proliferator-activated receptor regulates angiotensin II-stimulated phosphatidylinositol 3-kinase and mitogen-activated protein kinase in blood vessels in vivo. Hypertension, v. 47, n. 1, p. 102-108, Jan. 2006.

104 FERRARA, N.; DAVIS-SMYTH, T. The biology of vascular endothelial growth factor. Endocrine Reviews, v. 18, n. 1, p. 4-25, Feb. 1997. 
105 MURATA, T. et al. Peroxisome proliferator-activated receptor-gamma ligands inhibit choroidal neovascularization. Investigative Ophthalmology \& Visual Science, v. 41, n. 8, p. 2309-17, July 2000.

106 FUKUNAGA, Y. et al. Thiazolidinediones, peroxisome proliferator-activated receptor gamma agonists, regulate endothelial cell growth and secretion of vasoactive peptides. Atherosclerosis, v. 158, n. 1, p. 113-119, Sept. 2001.

107 FUJII, M. et al. Aldosterone inhibits endothelial morphogenesis and angiogenesis through the downregulation of vascular endothelial growth factor receptor-2 expression subsequent to peroxisome proliferator-activated receptor. Journal of Steroid Biochemistry and Molecular Biology, v. 129, n. 3-5, p. 145-152, Apr. 2012.

108 WOLF, D. et al. Endothelin-1 decreases endothelial PPAR signaling and impairs angiogenesis after chronic intrauterine pulmonary hypertension. AJP: Lung Cellular and Molecular Physiology, v. 306, n. 4, p. L361-L371, Feb. 2014.

109 ZHANG, F. et al. Peroxisome proliferator-activated receptor- $\gamma$ interrupts angiogenic signal transduction by transrepression of platelet-derived growth factor- $\beta$ receptor in hepatic stellate cells. Journal of Cell Science, v. 127, n. Pt 2, p. 305-314, Jan. 2014.

110 YANG, J. et al. Role of PPARy in renoprotection in Type 2 diabetes: molecular mechanisms and therapeutic potential: figure 1. Clinical Science, v. 116, n. 1, p. 17-26, Jan. 2009.

111 SARAFIDIS, P. A. et al. Effect of thiazolidinediones on albuminuria and proteinuria in diabetes: a meta-analysis. American Journal of Kidney Diseases, v. 55, n. 5, p. 835-847, May 2010.

$112 \mathrm{CHUNG}$, B. H. et al. Protective effect of peroxisome proliferator activated receptor gamma agonists on diabetic and non-diabetic renal diseases. Nephrology, v. 10, n. s2, p. S40-S43, Oct. 2005.

113 IGLESIAS, P.; DÍEZ, J. J. Peroxisome proliferator-activated receptor gamma agonists in renal disease. European Journal of Endocrinology, v. 154, n. 5, p. 613-621, May 2006.

114 IRWIN, J. J. et al. ZINC: a free tool to discover chemistry for biology. Journal of Chemical Information and Modeling, v. 52, n. 7, p. 1757-1768, 2012.

115 VAZ DE LIMA, L. A.; NASCIMENTO, A. S. MoIShaCS: a free and open source tool for ligand similarity identification based on Gaussian descriptors. European Journal of Medicinal Chemistry, v. 59, p. 296-303, Jan. 2013. doi: 10.1016/j.ejmech.2012.11.013.

116 MCPHERSON, A. Crystallization of biological macromolecules. Cold Spring Harbor, NY: Cold Spring Harbor Laboratory Press, 1999.

117 BERNARDES, C. E. S. Cristalização e polimorfismo na 4'-hidroxiacetofenona e estudo da energética de compostos do tipo hidroxifenilcarbonilo. 2008. 323 p. Tese (Doutorado em Química) - Departamento de Química e Bioquímica, Universidade de Lisboa, Lisboa, 2008.

$118 \mathrm{OHTO}$, U. et al. Crystal structure of human $\beta$-galactosidase: structural basis of $\mathrm{Gm} 1$ gangliosidosis and morquio B diseases. Journal of Biological Chemistry, v. 287, n. 3, p. 1801-1812, Jan. 2012. 
119 KABSCH, W. XDS. Acta Crystallographica D: biological crystallography, v. 66, n. Pt 2, p. 125-132, 2010.

120 EVANS, P. R. An introduction to data reduction: space-group determination, scaling and intensity statistics. Acta Crystallographica D: biological crystallography, v. 67, n. Pt 4, p. 282-292, 2011.

121 COLLABORATIVE COMPUTACIONAL PROJECT, N. M. The CCP4 suite: programs for protein crystallography. Acta Crystallographica D: biological crystallography, v. 50, n. Pt5, p. $760-763,1994$.

122 COLLABORATIVE COMPUTATIONAL PROJECT, NUMBER 4. The CCP4 suite: programs for protein crystallography. Acta Crystallographica Section D: biological crystallography, v. 50, n. 5, p. 760-763, Sept. 1994.

123 MCCOY, A. J. et al. Phaser crystallographic software. Journal of Applied Crystallography, v. 40, n. Pt4, p. 658-695, 2007.

124 BERMAN, H. M. et al. The protein data bank. Nucleic Acids Research, v. 28, n. 1, p. 235-242, 2000.

125 PUHL, A. C. et al. Mode of peroxisome proliferator-activated receptor $\mathrm{y}$ activation by luteolin. Molecular Pharmacology, v. 81, n. 6, p. 788-799, 2012.

126 MURSHUDOV, G.; VAGIN, A.; DODSON, E. Refinement of macromolecular structures by the maximum-likelihood method. Acta Crystallographica D: biological crystallography, v. 53, n. Pt 3, p. 240-255, 1997.

127 EMSLEY, P.; COWTAN, K. Coot: model-building tools for molecular graphics. Acta Crystallographica D: biological crystallography, v. 60, n. Pt 12, Pt 1, p. 2126-2132, 2004.

128 ADAMS, P. et al. PHENIX: a comprehensive Python-based system for macromolecular structure solution. Acta Crystallographica D: biological crystallography, v. 66, n. Pt 2, p. 213-221, 2010.

129 BRUNGER, A. T. Free R value: a novel statistical quantity for assessing the accuracy of crystal structures. Nature, v. 355, n. 6359, p. 472-475, 1992.

$130 \mathrm{CHEN}$, V. B. et al. MolProbity: all-atom structure validation for macromolecular crystallography. Acta Crystallographica D: biological crystallography, v. 66, n. Pt 1, p. 1221,2010

$131 \mathrm{LY}, \mathrm{Y}$. et al. Molecular recognition of nitrated fatty acids by PPAR gamma. Nature, v. 15, n. 8, p. 865-867, 2008.

132 MOTANI, A. et. al. INT131: a selective modulator of PPAR gamma. Journal of Molecular Biology, v. 386, n. 5, p. 1301-1311, 2009.

133 MILBURN, M. V. et al. Ligand binding and co-activator assembly of the peroxisome proliferator-activated receptor-gamma. Nature, v. 395, n. 6698, p. 137-143, Sept. 1998.

134 SCOTT, M. A. et al. Current methods of adipogenic differentiation of mesenchymal stem cells. Stem Cells and Development, v. 20, n. 10, p. 1793-804, Oct. 2011. 
135 AMERICAN HOME PRODUCTS CORPORATION. Kenneth L. Kees. Tetrazoles an their use as hypoglycemic agents. US4845231, 12 Feb. 1988, 4 July 1989 